\title{
Catalog of Earthquake Parameters and Description of Seismograph and Infrasound Stations at Alaskan Volcanoes-January 1, 2013, through December 31, 2017
}

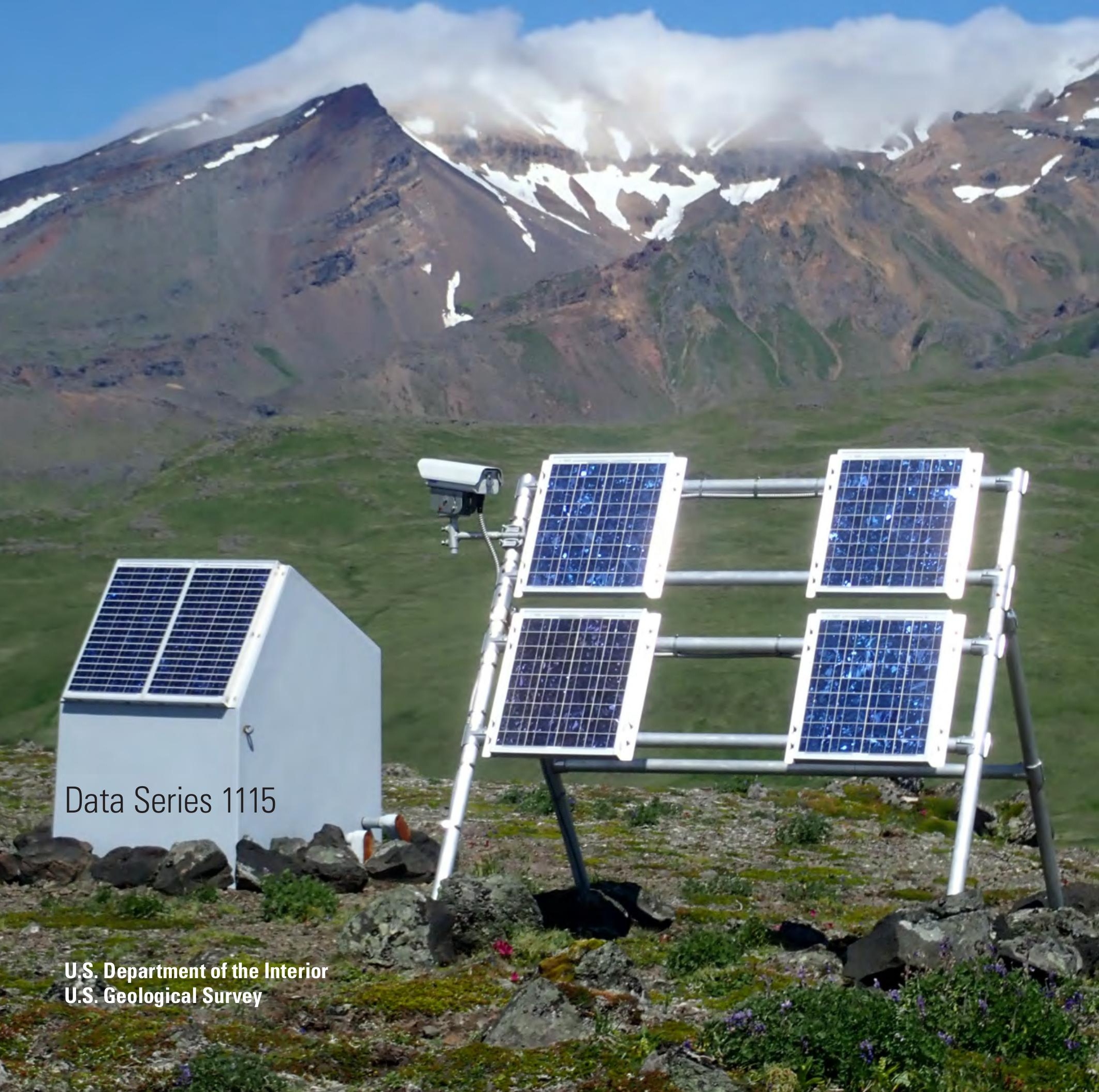


Cover. Photograph showing seismic station CLCO, at Concord Point, Chuginadak Island, Islands of Four Mountains, Aleutian Islands, Alaska. The south flank of little-studied Tana Volcano rises in the background. This remote, solar-powered seismic station also hosts the Cleveland Volcano web camera and an array of infrasound sensors. (Photograph by Max Kaufman, University of Alaska Fairbanks Geophysical Institute, used with permission.) 


\section{Catalog of Earthquake Parameters and Description of Seismograph and Infrasound Stations at Alaskan Volcanoes-January 1, 2013, through December 31, 2017}

By James P. Dixon, Scott D. Stihler, Matthew M. Haney, John J. Lyons, Dane M.

Ketner, Katherine M. Mulliken, Thomas Parker, John A. Power

Data Series 1115 


\title{
U.S. Department of the Interior DAVID BERNHARDT, Secretary
}

\author{
U.S. Geological Survey \\ James F. Reilly II, Director
}

U.S. Geological Survey, Reston, Virginia: 2019

For more information on the USGS - the Federal source for science about the Earth, its natural and living resources, natural hazards, and the environment-visit https://www.usgs.gov or call 1-888-ASK-USGS.

For an overview of USGS information products, including maps, imagery, and publications, visit https://store.usgs.gov.

Any use of trade, firm, or product names is for descriptive purposes only and does not imply endorsement by the U.S. Government.

Although this information product, for the most part, is in the public domain, it also may contain copyrighted materials as noted in the text. Permission to reproduce copyrighted items must be secured from the copyright owner.

\section{Suggested citation:}

Dixon, J.P., Stihler S.D., Haney, M.M., Lyons, J.J., Ketner, D.M., Mulliken, K.M., Parker, T., and Power, J.A., 2019, Catalog of earthquake parameters and description of seismograph and infrasound stations at Alaskan volcanoes-January 1, 2013, through December 31, 2017: U.S. Geological Survey Data Series 1115, 92 p., https://doi.org/10.3133/ ds 1115 .

ISSN 2327-638X (online) 


\section{Acknowledgments}

The contents of this report reflect a great deal of hard work by a large number of people, including Alaska Volcano Observatory, Alaska Earthquake Center (AEC), and U.S. Geological Survey (USGS) personnel and various students, interns, and volunteers. We thank the AEC, Global Seismograph Network, National Tsunami Warning Center, and Transportable Array for the use of their data. We thank Brian Shiro (USGS) and Gabrielle Tepp (USGS) for formal reviews of the text and figures. 


\section{Contents}

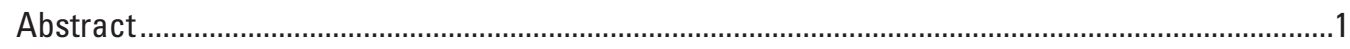

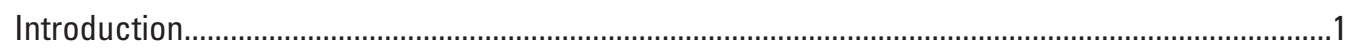

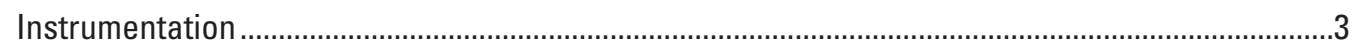

Data Acquisition and Processing.........................................................................................

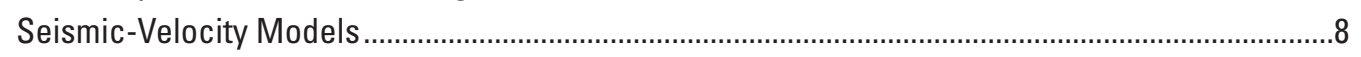

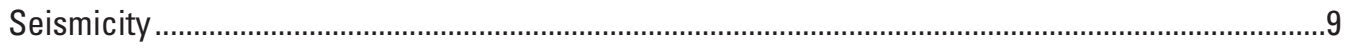

Summary

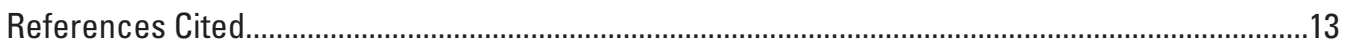

Appendix 1. Maps of Monitored Volcanoes with Earthquake Hypocenters in 2013-17 .................15

Appendix 2. Alaska Volcano Observatory Seismograph and Infrasound Stations in 2013-17 .......43

Appendix 3. Operational Status for Alaska Volcano Observatory Stations in 2013-17...................55

Appendix 4. Data Use Scores for Alaska Volcano Observatory Stations in 2013-17 .......................65

Appendix 5. Seismic-Velocity Models Used for Locating Earthquakes...........................................77

Appendix 6. Cylindrical Model Regions Used for Locating Earthquakes ...........................................83

Appendix 7. Description of Earthquake List Parameters ……......................................................

Appendix 8. Previous Alaska Volcano Observatory Earthquake Catalogs......................................89

Appendix 9. Selected Publications Using Alaska Volcano Observatory Data.................................91

\section{Figures}

1. Map showing location of volcanoes monitored by the Alaskan Volcano Observatory mentioned in this report. Red squares show locations of towns and other sites mentioned in this report.

2. Graph showing the number of Alaska Volcano Observatory seismograph and infrasound stations by type and year.

3. Map showing status of the transition from analog to digital telemetry for the Alaska Volcano Observatory volcano-monitoring network at the end of 2017 ...........5

4. Number of earthquakes located per year in the Alaska Volcano Observatory earthquake catalog, 1989-2017, and number of volcanoes with a seismograph network per year.....

1.1. Map of Alaska showing all earthquakes (open circles) located by the Alaska Volcano Observatory in 2013-17. Earthquakes are scaled by magnitude and the color of the symbols varies with depth.

1.2. Map showing summary plot of earthquakes located by the Alaska Volcano Observatory with the seismic-monitoring subnetwork at Mount Wrangell in 2013-17...

1.3. Map showing summary plot of earthquakes located by the Alaska Volcano Observatory with the seismic-monitoring subnetwork at Mount Spurr in 2013-17.18

1.4. Map showing summary plot of earthquakes located by the Alaska Volcano Observatory with the seismic-monitoring subnetwork at Redoubt Volcano in 2013-17..

1.5. Map showing summary plot of earthquakes located by the Alaska Volcano Observatory with the seismic-monitoring subnetwork at Iliamna Volcano in 2013-17 
1.6. Map showing summary plot of earthquakes located by the Alaska Volcano Observatory with the seismic-monitoring subnetwork at Augustine Volcano in 2013-17..

1.7. Map showing summary plot of earthquakes located by the Alaska Volcano Observatory with the seismic-monitoring subnetwork at Fourpeaked Mountain in 2013-17.

1.8. Map showing summary plot of earthquakes located by the Alaska Volcano Observatory with the seismic-monitoring subnetwork for the northern part of the Katmai volcanic cluster in 2013-17

1.9. Map showing summary plot of earthquakes located by the Alaska Volcano Observatory with the seismic-monitoring subnetwork for the southern part of the Katmai volcanic cluster in 2013-17

1.10. Map showing summary plot of earthquakes located by the Alaska Volcano Observatory with the seismic-monitoring subnetwork at Ugashik-Peulik Volcano in 2013-17.

1.11. Map showing summary plot of earthquakes located by the Alaska Volcano Observatory with the seismic-monitoring subnetwork at Aniakchak Crater in 2013-17.

1.12. Map showing summary plot of earthquakes located by the Alaska Volcano Observatory with the seismic-monitoring subnetwork at Mount Veniaminof in 2013-17.

1.13. Map showing summary plot of earthquakes located by the Alaska Volcano Observatory with the seismic-monitoring subnetwork at Pavlof Volcano in 2013-17.

1.14. Map showing summary plot of earthquakes located by the Alaska Volcano Observatory with the seismic-monitoring subnetwork at Mount Dutton in 2013-17.

1.15. Map showing summary plot of earthquakes located by the Alaska Volcano Observatory with the seismic-monitoring subnetwork at Shishaldin Volcano in 2013-17.

1.16. Map showing summary plot of earthquakes located by the Alaska Volcano Observatory with the seismic-monitoring subnetwork at Westdahl Peak in 2013-17.

1.17. Map showing summary plot of earthquakes located by the Alaska Volcano Observatory with the seismic-monitoring subnetwork at Akutan Peak in 2013-17

1.18. Map showing summary plot of earthquakes located by the Alaska Volcano Observatory with the seismic-monitoring subnetwork at Makushin Volcano in 2013-17.

1.19. Map showing summary plot of earthquakes located by the Alaska Volcano Observatory with the seismic-monitoring subnetwork at Okmok Caldera in 2013-17.

1.20. Map showing summary plot of earthquakes located by the Alaska Volcano Observatory with the seismic-monitoring subnetwork at Mount Cleveland in 2013-17. 
1.21. Map showing summary plot of earthquakes located by the Alaska Volcano Observatory with the seismic-monitoring subnetwork at Korovin Volcano in 2013-17..

1.22. Map showing summary plot of earthquakes located by the Alaska Volcano Observatory with the seismic-monitoring subnetwork at Great Sitkin Volcano in 2013-17...

1.23. Map showing summary plot of earthquakes located by the Alaska Volcano Observatory with the seismic-monitoring subnetwork at Kanaga Volcano in 2013-17..

1.24. Map showing summary plot of earthquakes located by the Alaska Volcano Observatory with the seismic-monitoring subnetwork at Tanaga Volcano in 2013-17..

1.25. Map showing summary plot of earthquakes located by the Alaska Volcano Observatory with the seismic-monitoring subnetwork at Mount Gareloi in 2013-17

1.26. Map showing summary plot of earthquakes located by the Alaska Volcano Observatory with the seismic-monitoring subnetwork at Mount Cerberus in 2013-17.

1.27. Map showing summary plot of earthquakes located by the Alaska Volcano Observatory with the seismic-monitoring subnetwork at Little Sitkin Volcano in 2013-17.

3.1. Image showing data availability for Alaska Volcano Observatory seismograph stations ACH to AUQ determined using the Incorporated Research Institutions for Seismology Gap/Overlap Analysis Tool (Stromme, 2000).

3.2. Image showing data availability for Alaska Volcano Observatory seismograph stations AUSB to CRP determined using the Incorporated Research Institutions for Seismology Gap/Overlap Analysis Tool (Stromme, 2000).

3.3. Image showing data availability for Alaska Volcano Observatory seismograph stations DFR to ISLZ determined using the Incorporated Research Institutions for Seismology Gap/Overlap Analysis Tool (Stromme, 2000).

3.4. Image showing data availability for Alaska Volcano Observatory seismograph stations ISNN to KOWE determined using the Incorporated Research Institutions for Seismology Gap/Overlap Analysis Tool (Stromme, 2000).

3.5. Image showing data availability for Alaska Volcano Observatory seismograph stations KVT to OKWR determined using the Incorporated Research Institutions for Seismology Gap/Overlap Analysis Tool (Stromme, 2000). 61

3.6. Image showing data availability for Alaska Volcano Observatory seismograph stations OPT to SPNN determined using the Incorporated Research Institutions for Seismology Gap/Overlap Analysis Tool (Stromme, 2000)

3.7. Image showing data availability for Alaska Volcano Observatory seismograph stations SPNW to ZRO determined using the Incorporated Research Institutions for Seismology Gap/Overlap Analysis Tool (Stromme, 2000) ............................................63

6.1. Map showing volcanic zones for the Cook Inlet volcanoes, Alaska...........................85

6.2. Map showing the volcanic zone for the Katmai volcanic cluster, Alaska..................85

6.3. Map showing the volcanic zones for Pavlof Volcano and Mount Dutton, Alaska .....86

6.4. Map showing the volcanic zones in the Adak region, Alaska ..................................86 


\section{Tables}

1. Number of permanent Alaska Volcano Observatory seismograph and infrasound stations/arrays by type and subnetwork at the end of 2017 ...

2. Number of Alaska Volcano Observatory (AVO) seismograph and infrasound stations by type and year.

3. Volcanic centers associated with each of the volcano seismic-monitoring subnetworks used by the Alaska Volcano Observatory..

4. Number of earthquakes located by the Alaska Volcano Observatory (AVO) within 20 kilometers of monitored volcanic centers in in 2013-17.

5. Number of earthquakes located per year in the Alaska Volcano Observatory (AVO) earthquake catalog, 1989-2017 .........................................................................10

6. Summary of notable seismic activity at Alaskan volcanoes for 2013-17 ...................12

7. Alaska Volcano Observatory Annual Summary reports for 2013-2015.......................12

2.1. Seismograph and infrasound stations of the Akutan Peak subnetwork, operated by the Alaska Volcano Observatory......

2.2. Seismograph stations of the Aniakchak Crater subnetwork, operated by the Alaska Volcano Observatory.

2.3. Seismograph stations of the Augustine Volcano subnetwork, operated by the Alaska Volcano Observatory.

2.4. Seismograph stations of the Mount Cerberus subnetwork, operated by the Alaska Volcano Observatory.

2.5. Seismograph and stations of the Mount Cleveland subnetwork, operated by the Alaska Volcano Observatory.

2.6. Seismograph stations of the Mount Dutton subnetwork, operated by the Alaska Volcano Observatory

2.7. Seismograph of the Fourpeaked Mountain subnetwork, operated by the Alaska Volcano Observatory.

2.8. Seismograph stations of the Mount Gareloi subnetwork, operated by the Alaska Volcano Observatory.

2.9. Seismograph of the Great Sitkin Volcano subnetwork, operated by the Alaska Volcano Observatory.

2.10. Seismograph stations of the lliamna Volcano subnetwork, operated by the Alaska Volcano Observatory

2.11. Seismograph stations of the Kanaga Volcano subnetwork, operated by the Alaska Volcano Observatory

2.12. Seismograph stations of the Katmai volcanic cluster subnetwork, operated by the Alaska Volcano Observatory.

2.13. Seismograph stations of the Korovin Volcano subnetwork, operated by the Alaska Volcano Observatory.

2.14. Seismograph stations of the Little Sitkin Volcano subnetwork, operated by the Alaska Volcano Observatory

2.15. Seismograph stations of the Makushin Volcano subnetwork, operated by the Alaska Volcano Observatory

2.16. Seismograph and infrasound stations of the Okmok Caldera subnetwork, operated by the Alaska Volcano Observatory. 
2.17. Seismograph stations of the Pavlof Volcano subnetwork, operated by the Alaska Volcano Observatory.

2.18. Seismograph stations of the Redoubt Volcano subnetwork, operated by the Alaska Volcano Observatory. .50

2.19. Seismograph stations of the Shishaldin Volcano subnetwork, operated by the Alaska Volcano Observatory

2.20. Seismograph stations of the Mount Spurr subnetwork, operated by the Alaska Volcano Observatory.

2.21. Seismograph stations of the Tanaga Volcano subnetwork, operated by the Alaska Volcano Observatory

2.22. Seismograph stations of the Ugashik-Peulik Volcano subnetwork, operated by the Alaska Volcano Observatory

2.23. Seismograph stations of the Mount Veniaminof subnetwork, operated by the Alaska Volcano Observatory

2.24. Seismograph stations of the Westdahl Peak subnetwork, operated by the Alaska Volcano Observatory.

2.25. Seismograph stations of the Mount Wrangell subnetwork, operated by the Alaska Volcano Observatory

2.26. Regional seismograph and infrasound stations operated by the Alaska Volcano Observatory.

3.1. Summary of data availability for Alaska Volcano Observatory (AVO) stations in 2013-17 determined using to the Incorporated Research Institutions for Seismology (IRIS) Gap/Overlap Analysis Tool (Stromme, 2000)

4.1. Data-use scores by year for Alaska Volcano Observatory seismograph stations in the Akutan Peak subnetwork, 2013-17

4.2. Data-use scores by year for Alaska Volcano Observatory seismograph stations in the Aniakchak Crater subnetwork, 2013-17

4.3. Data-use scores by year for Alaska Volcano Observatory seismograph stations in the Augustine Volcano subnetwork, 2013-17

4.4. Data-use scores by year for Alaska Volcano Observatory seismograph stations in the Mount Cerberus subnetwork, 2013-17.

4.5. Data-use scores by year for Alaska Volcano Observatory seismograph stations in the Mount Cleveland subnetwork, 2013-17...

4.6. Data-use scores by year for Alaska Volcano Observatory seismograph stations in the Mount Dutton subnetwork, 2013-17

4.7. Data-use scores by year for Alaska Volcano Observatory seismograph stations in the Fourpeaked Mountain subnetwork, 2013-17

4.8. Data-use scores by year for Alaska Volcano Observatory seismograph stations in the Mount Gareloi subnetwork, 2013-17

4.9. Data-use scores by year for Alaska Volcano Observatory seismograph stations in the Great Sitkin Volcano subnetwork, 2013-17.

4.10. Data-use scores by year for Alaska Volcano Observatory seismograph stations in the Iliamna Volcano subnetwork, 2013-17

4.11. Data-use scores by year for Alaska Volcano Observatory seismograph stations in the Kanaga Volcano subnetwork, 2013-17.

4.12. Data-use scores by year for Alaska Volcano Observatory seismograph stations in the Katmai volcanic cluster subnetwork, 2013-17

4.13. Data-use scores by year for Alaska Volcano Observatory seismograph stations in the Korovin Volcano subnetwork, 2013-17. 
4.14. Data-use scores by year for Alaska Volcano Observatory seismograph stations in the Little Sitkin Volcano subnetwork, 2013-17.

4.15. Data-use scores by year for Alaska Volcano Observatory seismograph stations in the Makushin Volcano subnetwork, 2013-17

4.16. Data-use scores by year for Alaska Volcano Observatory seismograph stations in the Okmok Caldera subnetwork, 2013-17

4.17. Data-use scores by year for Alaska Volcano Observatory seismograph stations in the Pavlof Volcano subnetwork, 2013-17

4.18. Data-use scores by year for Alaska Volcano Observatory seismograph stations in the Redoubt Volcano subnetwork, 2013-17

4.19. Data-use scores by year for Alaska Volcano Observatory seismograph stations in the Shishaldin Volcano subnetwork, 2013-17

4.20. Data-use scores by year for Alaska Volcano Observatory seismograph stations in the Mount Spurr subnetwork, 2013-17.

4.21. Data-use scores by year for Alaska Volcano Observatory seismograph stations in the Tanaga Volcano subnetwork, 2013-17.

4.22. Data-use scores by year for Alaska Volcano Observatory seismograph stations in the Ugahik-Peulik Volcano subnetwork, 2013-17

4.23. Data-use scores by year for Alaska Volcano Observatory seismograph stations in the Mount Veniaminof subnetwork, 2013-17.

4.24. Data-use scores by year for Alaska Volcano Observatory seismograph stations in the Westdahl Peak subnetwork, 2013-17.

4.25. Data-use scores by year for Alaska Volcano Observatory seismograph stations in the Mount Wrangell subnetwork, 2013-17.

4.26. Data-use scores by year for Alaska Volcano Observatory regional seismograph stations, 2013-17.

5.1. Velocity model used by the Alaska Volcano Observatory for Akutan Peak (Power and others, 1996) 78

5.2. Velocity model used by the Alaska Volcano Observatory for the Andreanof Islands region (Toth and Kisslinger, 1984).

5.3. Velocity model used by the Alaska Volcano Observatory for Augustine Volcano (Power, 1988).

5.4. Velocity model used by the Alaska Volcano Observatory for Cold Bay region (McNutt and Jacob, 1986)

5.5. Velocity model used by the Alaska Volcano Observatory for Iliamna Volcano (Roman and others, 2001)

5.6. Velocity model used by the Alaska Volcano Observatory for the Katmai volcanic cluster (Searcy, 2003).

5.7. Velocity model used by the Alaska Volcano Observatory for Makushin Volcano (Cheryl Searcy, written communications, 2010).

5.8. Velocity model used by the Alaska Volcano Observatory for Okmok Caldera (Masterlark and others, 2010).

5.9. Velocity model used by the Alaska Volcano Observatory for Redoubt Volcano (Lahr and others, 1994).

5.10. Velocity model used by the Alaska Volcano Observatory for Mount Spurr (Jolly and others, 1994).

5.11. Velocity model used by the Alaska Volcano Observatory for Tanaga Volcano (Power, written commun., 2005). 
5.12. Velocity model used by the Alaska Volcano Observatory for Mount Veniaminof (Sánchez, 2005)

5.13. Velocity model used by the Alaska Volcano Observatory for Westdahl Peak (Dixon and others, 2005).

5.14. Regional velocity model used by the Alaska Volcano Observatory (Fogleman and others, 1993)

6.1. Cylindrical extent parameters for local velocity models used by the Alaska Volcano Observatory at monitored volcanoes.

7.1. Event codes used in the Alaska Volcano Observatory (AVO) catalog of seismic events.

7.2. Event regions and the volcanic center in each geographical region used in the Alaska Volcano Observatory (AVO) catalog of seismic events

\section{Conversion Factors}

International System of Units to U.S. customary units

\begin{tabular}{lcc}
\hline Multiply & By & To obtain \\
\hline \multicolumn{3}{c}{ Length } \\
\hline kilometer $(\mathrm{km})$ & 0.6214 & mile $(\mathrm{mi})$ \\
\hline \multicolumn{3}{c}{ Pressure } \\
\hline pascal $(\mathrm{Pa})$ & 0.2088 & pound per square foot $\left(\mathrm{lb} / \mathrm{ft}^{2}\right)$ \\
\hline
\end{tabular}




\section{Abbreviations}

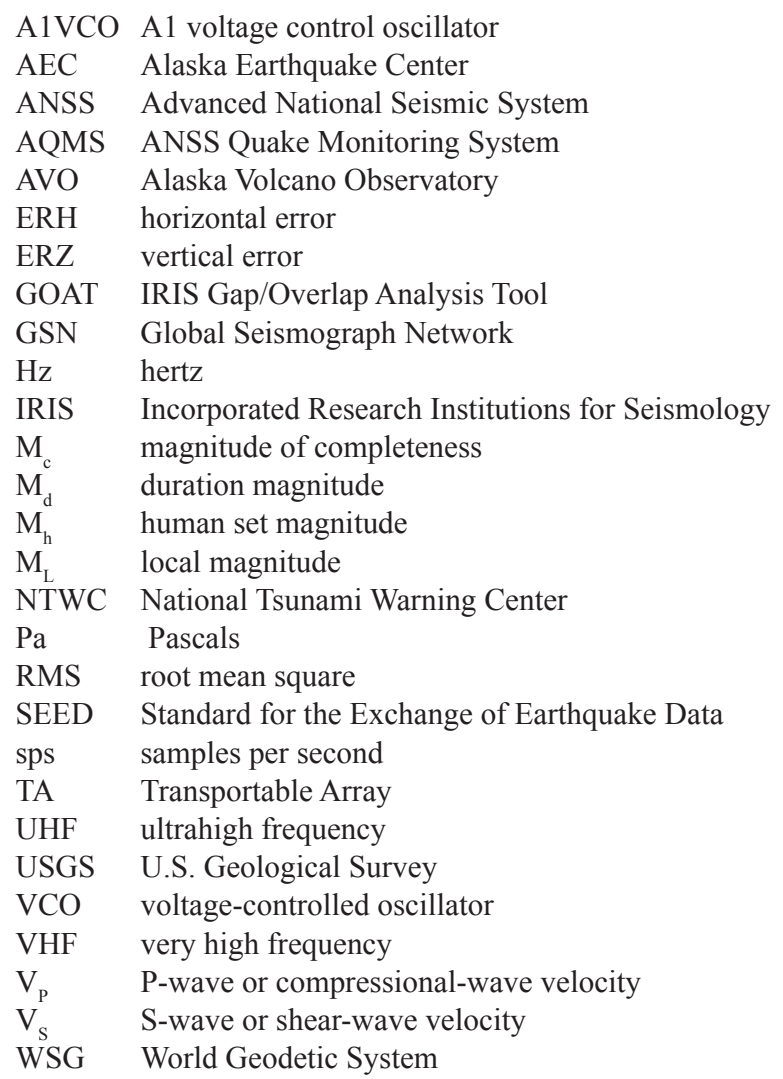

\section{Datum}

Horizontal coordinate information is referenced to the World Geodetic System 1984 (WGS 84). 
"This page intentionally left blank" 


\title{
Catalog of Earthquake Parameters and Description of Seismograph and Infrasound Stations at Alaskan Volcanoes-January 1, 2013, through December 31, 2017
}

\author{
By James P. Dixon, ${ }^{1}$ Scott D. Stihler, ${ }^{2}$ Matthew M. Haney, ${ }^{1}$ John J. Lyons, ${ }^{1}$ Dane M. Ketner, ${ }^{1}$ Katherine M. \\ Mulliken, ${ }^{3}$ Thomas Parker, ${ }^{1}$ and John A. Power ${ }^{1}$
}

\section{Abstract}

Between January 1, 2013, and December 31, 2017, the Alaska Volcano Observatory (AVO) located a total of 28,172 earthquakes at volcanoes in Alaska. The annual totals are $3,840,5,819,5,297,6,151$, and 7,065 earthquakes for the years 2013 through 2017, respectively. This represents an average of 5,634 earthquakes per year, which is comparable to the yearly number of earthquakes AVO located in the previous decade when AVO monitored a similar number of volcanoes. During the reporting period, there was significant seismic activity at 20 of the 34 volcanoes monitored by a seismograph network (Akutan Peak, Aniakchak Crater, Augustine, Mount Cerberus, Mount Cleveland, Fourpeaked Mountain, Mount Gareloi, Great Sitkin, Ilimana, Kanaga, Korovin, Makushin, Mount Martin, Okmok Caldera, Pavlof, Shishaldin, Mount Spurr, Tanaga, Ugashik-Peulik, and Mount Veniaminof) and two volcanoes without a monitoring network (Mount Recheshnoi and Bogoslof Island). Instrumentation highlights for this period include the establishment of a new subnetwork on Mount Cleveland, an accelerated transition from analog to digital telemetry at most subnetworks, and an increased number of broadband and infrasound sensors throughout the AVO network. The operational highlight was the return of seismic monitoring at Korovin and Ugashik-Peulik Volcanoes following network repairs. This catalog includes hypocenters, magnitudes, and statistics of the earthquakes located in 2013-17, along with the associated station parameters, and velocity models.

\section{Introduction}

In 1988, the Alaska Volcano Observatory (AVO) was established as a cooperative program of the U.S. Geological Survey (USGS), the Geophysical Institute at the University of

\footnotetext{
${ }^{1}$ U.S. Geological Survey.

${ }^{2}$ University of Alaska Fairbanks Geophysical Institute.

${ }^{3}$ Alaska Division of Geological \& Geophysical Surveys.
}

Alaska Fairbanks, and the Alaska Division of Geological \& Geophysical Surveys. AVO initially monitored four volcanoes in the Cook Inlet region (Mount Spurr, Redoubt Volcano, Iliamna Volcano, and Augustine Volcano) and in the following three decades, established seismograph networks on 34 of the 54 historically active volcanoes in Alaska (Cameron and Schaefer, 2016) (fig.1). The primary objectives of the AVO seismic program are the real-time seismic monitoring of active and potentially hazardous Alaskan volcanoes and the investigation of seismic processes associated with active volcanism.

Between January 1, 2013, and December 31, 2017, the AVO located a total of 28,172 earthquakes at volcanoes in Alaska. The annual totals are 3,840, 5,819, 5,297, 6,151, and 7,065 earthquakes, respectively, for the years 2013 through 2017 , respectively. This represents an average of 5,634 earthquakes per year, which is comparable to the yearly number of earthquakes AVO located in the previous decade when AVO monitored a similar number of volcanoes. During the reporting period, there was significant seismic activity at 20 of the 34 volcanoes monitored by a seismograph network.

The seismically monitored volcano list includes volcanoes with a local seismograph network designed for the location of earthquakes in the vicinity of the volcano and a period of recording exceeding 6 months without prolonged station outages. The 29 monitored volcanoes are shown in figure 1 . Five of the 34 historically active volcanic centers with seismograph networks were not on the formal list of permanently monitored volcanoes in the AVO weekly update at the end of 2017. Fourpeaked Mountain was delisted on February 8, 2014, due to the failure of all seismograph stations.

Little Sitkin, Mount Cerberus (the active vent on Semisopochnoi Island), and Mount Wrangell (unlisted in 2012) volcanoes remained off the official monitored list. The Little Sitkin and Cerberus subnetworks do not have stable telemetry and the Wrangell subnetwork was too recently reestablished to be listed. Mount Cleveland, with two seismograph stations, does not have a sufficient number of stations to locate most earthquakes that occur in the Islands of the Four Mountains (fig. 1). Korovin and Ugashik-Peulik Volcanoes were reinstated on the formal list of permanently monitored volcanoes on February 21, 2013, and May 22, 2013, respectively. Between 2013 and 2017, Aniakchak Crater was removed on January 24, 2014, 

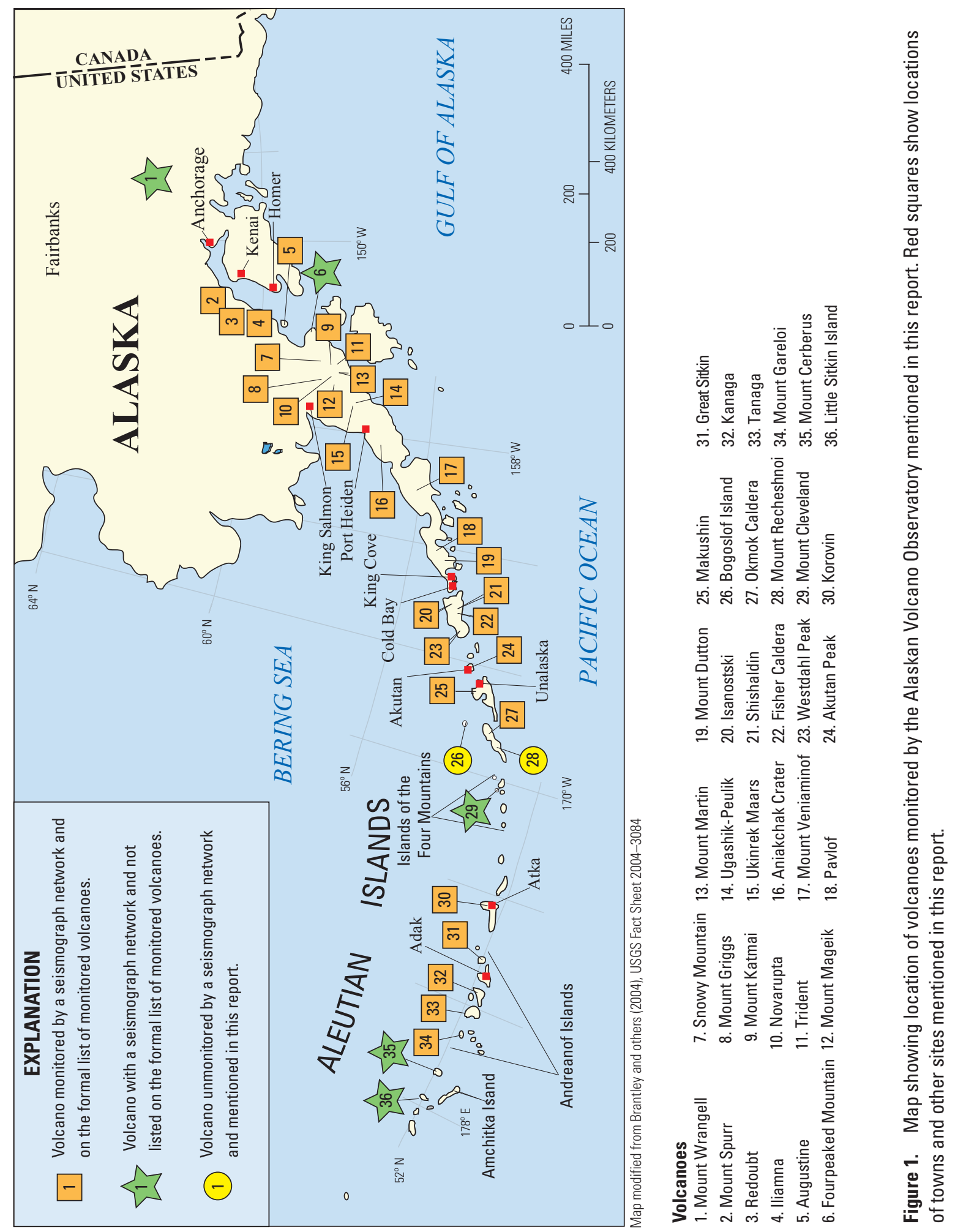
and added back on October 23, 2015. All three of the subnetworks added back to the formal monitored list had significant maintenance performed to upgrade network infrastructure.

This report describes the type and location of (1) seismograph and infrasound instrumentation deployed in the field; (2) earthquake detection, recording, analysis, and data archival systems; (3) seismic-velocity models used for earthquake locations; and (4) a summary of earthquakes located in 2013-17. A summary of earthquake origin times, hypocenters, magnitudes, and location quality statistics (headers described in appendix 7), and a metadata file for the AVO seismograph network (including but not limited to station location, station type, and system-response information) in the format of a dataless Standard for the Exchange of Earthquake Data (SEED) volume (International Federation of Digital Seismograph Networks, 2012) are included in a data supplement to this report (available only online at https://doi.org/10.3133/ds1115).

\section{Instrumentation}

The permanent AVO seismograph network is composed of 25 subnetworks with an average of 8 seismograph stations each and 10 regional seismograph stations for a total of 212 stations at the end of 2017 (table 1, fig. 2). In the past 5 years, ten new seismograph stations were established. Six broadband stations were added to the Augustine subnetwork over a 3-year period (two in 2013, one in 2014, and three in 2015). Two short-period seismograph stations were installed on Cleveland Volcano in 2014. The final new installations were within the Iliamna subnetwork - a broadband station in 2015 and a threecomponent short-period station in 2016. Additionally, two station installations were direct replacements for older stations. On Pavlof Volcano, PV6A was established in 2016 north of where PV6 had been located before its destruction in a previous Pavlof eruption, giving it a greater chance of surviving a future eruption. On Mount Wrangell, WAZA was removed in 2016 and reoccupied in 2017.

The composition of the AVO network is slowly transitioning from a short-period network to a broadband network (fig. 2, table 2). As new seismograph stations are installed, broadband sensors are the preferred instrument choice for these new sites. As opportunities present themselves, shortperiod sensors are being replaced with broadband sensors with a dozen short-period stations converted in the past 5 years. As a result, the number of broadband seismograph stations nearly doubled over the past 5 years and the proportion of broadband sites moved from 16 percent in 2012 to 29 percent in 2017 . At the end of 2017, the AVO seismograph network consisted of 172 short-period and 62 broadband stations.

AVO is increasingly using infrasound sensors to detect eruptive activity. Stand-alone microphones and infrasound arrays are used in the monitoring of volcanoes with and without local seismograph instrumentation. Infrasound sensors have been co-located with seismograph sensors for decades with increasing numbers installed in the last 8 years in the AVO network. Where infrasound sensors are co-located, typically the sensor was a single-channel infrasound station. However, three infrasound arrays are co-located with seismograph stations. The four-element Akutan array is collocated with AKS; the five-element Cleveland array is collocated with CLCO; and the six-element Sand Point array (SDPI) is co-located with the National Tsunami Warning Center seismograph station SDPT. Stand-alone infrasound arrays are located on Umnak Island (OKIF) and in Adak, Alaska (ADKI). OKIF is a four-element array outside the Okmok Caldera, whereas ADKI is a six-element array between Kanaga and Great Sitkin Volcanoes. The use of infrasound arrays as opposed to single stations, allows AVO to use the relative arrival times of acoustic waves on each sensor to determine the source of the infrasound signal.

The single-component short-period seismograph stations were equipped with either Sercel L-4 or Teledyne-Geotech $\mathrm{S}-13$ seismometers with a natural period of 1 hertz $(\mathrm{Hz})$. AVO also operated three-component, short-period instruments during 2013-17. Such sites used L-4, Sercel L-22, or S-13 seismometers. The L-22 seismometer has a natural period of $2 \mathrm{~Hz}$. Broadband stations were operated with either a Güralp CMG-40T seismometer (frequency range: 0.033-50 $\mathrm{Hz}$ ), Güralp CMG-6TD seismometer (frequency range: 0.033-50 Hz), Nanometrics Trillium Compact (frequency range: $0.008-100 \mathrm{~Hz}$ ), or Nanometrics Trillium 40 seismometer (frequency range: $0.025-50 \mathrm{~Hz}$ ). The Augustine Volcano subnetwork has the only strong-motion station (AU22) in the AVO seismograph network used a Kinemetrics Episensor EST strong-motion sensor (frequency range is $0-500 \mathrm{~Hz}$ ) and was collocated with a broadband sensor.

The majority of short-period stations ( 88 percent) were digitized at 100 samples per second (sps). The Mount Cerberus and Little Sitkin Island subnetworks were recorded at $50 \mathrm{sps}$ due to limitations in data rates using very small aperture terminal telemetry between the recording hubs located on Amchitka Island and Anchorage. Broadband stations were digitized at $50 \mathrm{sps}$ with the exception of IVE in the Iliamna Volcano subnetwork, which was recorded at $20 \mathrm{sps}$ due to poor telemetry.

Infrasound sensors in the AVO network come primarily from the Chaparral Physics brand. Models in use are series M2, M21/25 and M60/64 infrasound sensors. The series M21/25 sensors are used at three of the five infrasound arrays operated by AVO (OKIF, AKS, ADKI). The other two infrasound arrays (CLCO and SDPI) use sensors developed by the USGS Cascades Volcano Observatory. As short-period stations are upgraded to digital broadbands, hut-mounted single station infrasound sensors (Chaparral model M64) are being added at some sites. These are ultra-high-pressure variations of the M64 and can record as much as $+/-1,000$ pascal $(\mathrm{Pa})$ on scale, which is useful for recording strong explosions close to the source. Chaparrel M2 series microphones are used in 


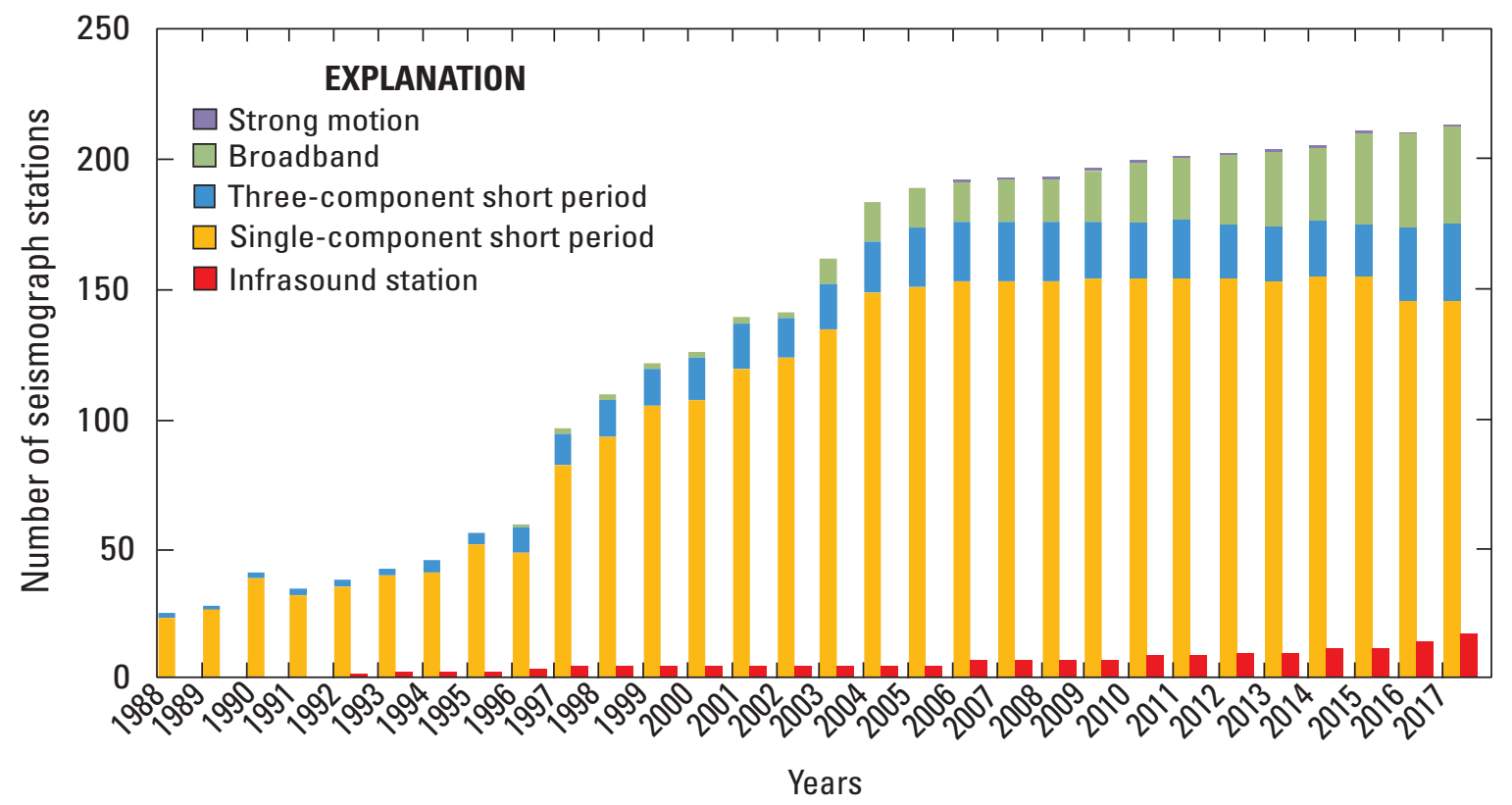

Figure 2. Graph showing the number of Alaska Volcano Observatory seismograph and infrasound stations by type and year.

infrasound installations that were established before 2007. Infrasound sample rates typically are $50 \mathrm{sps}$, although some stations record at $100 \mathrm{sps}$, including most arrays and CLES in the Cleveland subnetwork.

When available, calibration information in the form of poles and zeros, for each seismograph and infrasound sensor is included in the dataless SEED volume that can be found in the data supplement to this report and available from AVO offices and the Incorporated Research Institutions for Seismology (IRIS). A description of how instrument corrections are created for AVO seismograph stations can be found in Haney and others (2012). Instrument specifications are available online from the instrument manufacturers.

Data from AVO seismograph stations are increasingly telemetered with digital telemetry. Current analog telemetry links uses voltage-controlled oscillators (VCOs) to transform the signals generated by the seismometer from a voltage to a frequency-modulated carrier suitable for transmission over a radio link or telephone circuit. AVO uses VCOs developed by McChesney (1999) to modulate signals in the field with one exception-Mount Spurr seismograph station NCG uses an A1 voltage control oscillator (A1VCO) (Rogers and others, 1980). Signals are transmitted by ultrahigh frequency (UHF) and very high frequency (VHF) radio from station sites to communication hubs located throughout Alaska, where the signal is digitized and forwarded to the AVO in Anchorage. Digital telemetry links are accomplished with spread-spectrum radios, taking signals digitized at the field sites to AVO communication hubs. These data were forwarded to AVO offices in Anchorage through high-speed digital circuits. Progress moving from analog to digital telemetry is shown in figure 3.

Locations for all AVO stations are shown in appendix 1 with locations tabulated in appendix 2 . A measure of each station's operational status for the catalog period is shown in appendix 3 using the IRIS Gap/Overlap Analysis Tool (Stromme, 2000) and in appendix 4 with data-use scores, a normalized measure of the number of P-wave phase arrivals by station in the AVO earthquake catalog developed by Matt Haney (AVO, written commun., 2018).

\section{Data Acquisition and Processing}

Data acquisition for the AVO seismograph and infrasound network for 2013-17 used the Advanced National Seismic System (ANSS) Quake Monitoring System (AQMS). AQMS is an integrated data acquisition and processing system derived from software developed as part of the TriNet project (Hauksson and others, 2003) that incorporates Earthworm modules (Johnson and others, 1995) for data acquisition and event detection. The Jiggle software package (Hauksson and others, 2003; U.S. Geological Survey, 2018) is used to time phase arrivals and determine magnitudes. Earthquake hypocenters were calculated using Hypoinverse (Klein, 2002).

Earthquakes were detected using the Earthworm modules carlstatrig and carlsubtrig, with the carlstatrig parameters set as follows - long-term-average time $=8$ seconds, ratio $=2.3$, and quiet $=4$. Three station triggers from the carlstatrig module are required for an event to trigger carlsubtrig to create an event record. Carlsubtrig was modified such that each triggered record is identified with the triggering network (table 3 ). If four or more subnetworks triggered on the same event, the trigger was tagged as a regional event. About one third of all triggers are auto located. All data is stored in mini-SEED format (International Federation of Digital Seismograph Networks, 2012). Infrasound signals were detected by in-house 


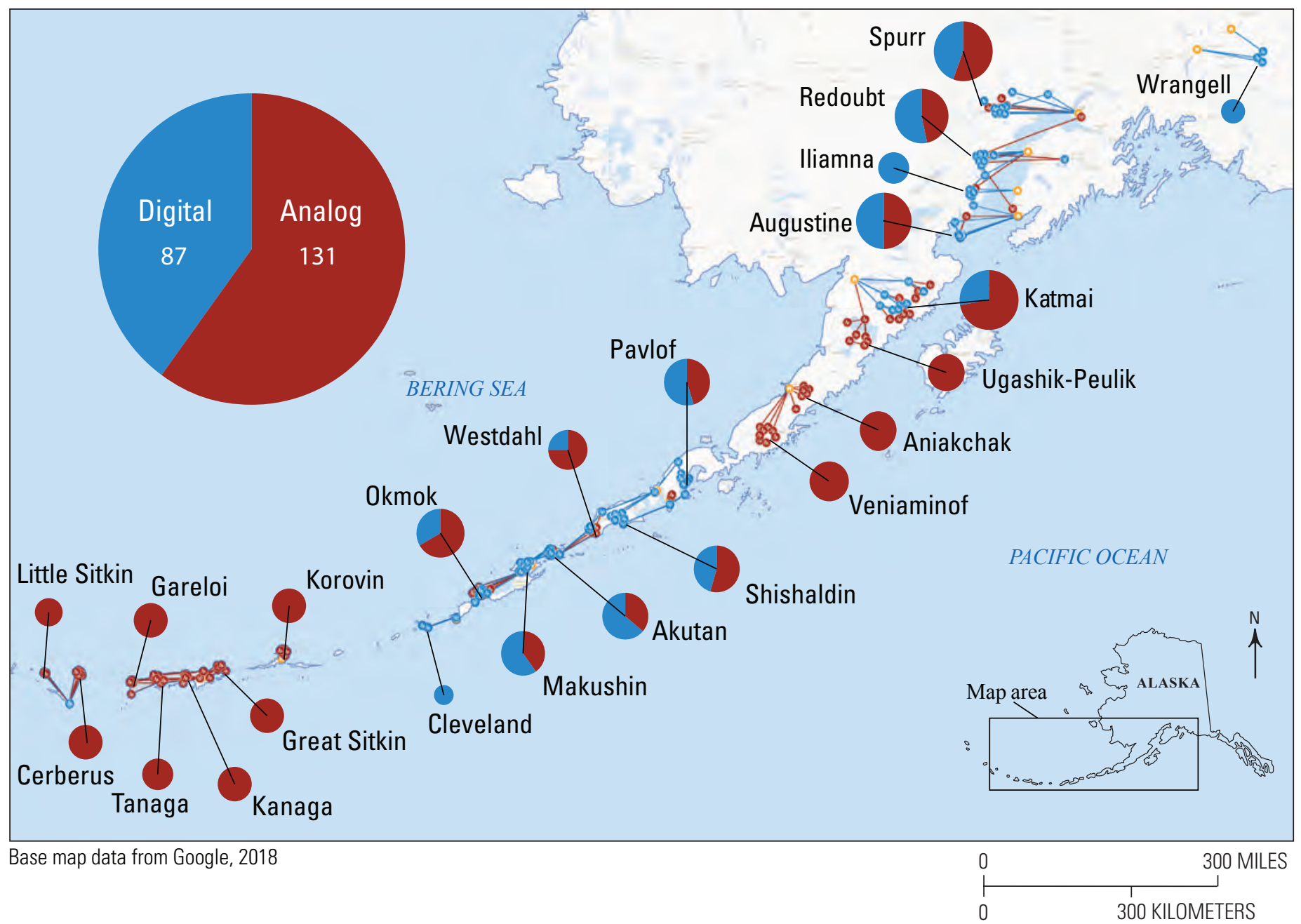

Figure 3. Map showing status of the transition from analog to digital telemetry for the Alaska Volcano Observatory volcano-monitoring network at the end of 2017. The progress for each subnetwork is shown by small circles with the percentage of stations with digital telemetry shown by the blue color. The overall progress is shown in the large circle with the number of sites using digital telemetry (87 sites) and those using analog telemetry (131 sites). Individual sites that record data digitally are shown by blue dots with digital links shown by blue lines. Red dots and lines show analog recording sites and links. The Fourpeaked Mountain network is not shown because the telemetry links are inoperable and will be replaced with digital links at some future date. The Mount Dutton seismograph network is not shown because the sites use either Pavlof Volcano or Shishaldin Volcano telemetry links. See table 3 for a listing of volcanoes being monitored in each subnetwork.

event detection algorithms, which triggered alarms that prompted AVO staff to determine the source.

Each event trigger was visually inspected, and false triggers were deleted. Earthquakes with a P- and S-wave separation of greater than 5 seconds on the closest station were assumed to come from regional sources and typically were not located; however, the trigger was preserved. Each finalized hypocenter meets three minimum parameters - three P-phases, two S-phases, and standard hypocentral errors less than 15 kilometers $(\mathrm{km})$. If on reevaluation, the minimum parameters could not be met, the event was removed from the final catalog listing but retained in the AQMS database. Event picks and location information for events that met AVO minimum parameters were tagged as "finalized" and saved in the AQMS database. Waveforms for individual located events were saved in mini-SEED format. The average root-mean-square (RMS) travel-time error for earthquakes located in 2013-17 was 0.14 seconds, and the average vertical and horizontal hypocentral errors were $1.35 \mathrm{~km}$ and $0.94 \mathrm{~km}$, respectively. For the earthquakes appearing in the 2013-17 AVO catalog, 95 percent had an average RMS travel-time error less than 0.32 .

At the time of publication, all hypocentral locations of earthquakes in the AVO seismic catalog have been made available as part of the ANSS Comprehensive Earthquake Catalog, ComCat (see https://earthquake.usgs.gov/data/comcat/), and are added on a daily basis. An effort started in 2016 to relocate the entire AVO catalog with the aim of obtaining more consistent locations was completed in 2019 (Power and others, 2019). Continuous waveform data for the majority of AVO seismograph and infrasound stations, whose availability 
Table 1. Number of permanent Alaska Volcano Observatory seismograph and infrasound stations/arrays by type and subnetwork at the end of 2017.

[See appendixies 1-4 for station details and operational status; See table 3 for a listing of volcanoes being monitored in each subnetwork. ]

\begin{tabular}{|c|c|c|c|c|c|c|c|}
\hline $\begin{array}{c}\text { Volcano } \\
\text { subnetwork }\end{array}$ & $\begin{array}{l}\text { Seismograph } \\
\text { stations }\end{array}$ & $\begin{array}{c}\text { Station } \\
\text { components }\end{array}$ & $\begin{array}{l}\text { Single-component } \\
\text { short-period } \\
\text { stations }\end{array}$ & $\begin{array}{c}\text { Three-component } \\
\text { short-period } \\
\text { stations }\end{array}$ & $\begin{array}{c}\text { Three-component } \\
\text { broadband } \\
\text { stations }\end{array}$ & $\begin{array}{c}\text { Three-component } \\
\text { strong-motion } \\
\text { stations }\end{array}$ & $\begin{array}{c}\text { Infrasound } \\
\text { stations or } \\
\text { arrays }\end{array}$ \\
\hline Akutan & 12 & 33 & 3 & 1 & 9 & 0 & 1 \\
\hline Aniakchak & 6 & 6 & 6 & 0 & 0 & 0 & 0 \\
\hline Augustine & 15 & 39 & 7 & 1 & 8 & 1 & 1 \\
\hline Cerberus & 6 & 8 & 5 & 1 & 0 & 0 & 0 \\
\hline Cleveland & 2 & 8 & 2 & 0 & 2 & 0 & 2 \\
\hline Dutton & 5 & 5 & 5 & 0 & 0 & 0 & 0 \\
\hline Fourpeaked & 4 & 7 & 4 & 0 & 0 & 0 & 2 \\
\hline Gareloi & 6 & 8 & 5 & 1 & 0 & 0 & 0 \\
\hline Great Sitkin & 6 & 8 & 5 & 1 & 0 & 0 & 0 \\
\hline Iliamna & 8 & 24 & 3 & 4 & 3 & 0 & 0 \\
\hline Kanaga & 6 & 6 & 6 & 0 & 0 & 0 & 0 \\
\hline Katmai & 20 & 34 & 13 & 2 & 5 & 0 & 0 \\
\hline Korovin & 7 & 9 & 6 & 1 & 0 & 0 & 0 \\
\hline Little Sitkin & 4 & 6 & 3 & 1 & 0 & 0 & 0 \\
\hline Makushin & 7 & 24 & 3 & 0 & 7 & 0 & 1 \\
\hline Okmok & 13 & 21 & 9 & 0 & 4 & 0 & 1 \\
\hline Pavlof & 7 & 23 & 5 & 3 & 3 & 0 & 4 \\
\hline Redoubt & 12 & 31 & 6 & 2 & 6 & 0 & 1 \\
\hline Shishaldin & 7 & 23 & 5 & 2 & 4 & 0 & 1 \\
\hline Spurr & 17 & 34 & 10 & 1 & 7 & 0 & 0 \\
\hline Tanaga & 6 & 8 & 5 & 1 & 0 & 0 & 0 \\
\hline $\begin{array}{l}\text { Ugashik- } \\
\text { Peulik }\end{array}$ & 7 & 9 & 6 & 1 & 0 & 0 & 0 \\
\hline Veniaminof & 9 & 9 & 9 & 0 & 0 & 0 & 0 \\
\hline Westdahl & 6 & 11 & 5 & 1 & 1 & 0 & 0 \\
\hline Wrangell & 4 & 10 & 1 & 1 & 2 & 0 & 0 \\
\hline $\begin{array}{l}\text { Regional } \\
\text { Stations } \\
\end{array}$ & 10 & 15 & 9 & 1 & 1 & 0 & 2 \\
\hline Totals & 212 & 419 & 146 & 26 & 62 & 1 & 16 \\
\hline
\end{tabular}


Table 2. Number of Alaska Volcano Observatory seismograph and infrasound stations by type and year.

\begin{tabular}{|c|c|c|c|c|c|c|c|}
\hline Year & $\begin{array}{l}\text { Seismograph } \\
\text { stations }\end{array}$ & $\begin{array}{c}\text { Station } \\
\text { components }\end{array}$ & $\begin{array}{l}\text { Single-component } \\
\text { short-period } \\
\text { stations }\end{array}$ & $\begin{array}{l}\text { Three-component } \\
\text { short-period } \\
\text { stations }\end{array}$ & $\begin{array}{c}\text { Three-component } \\
\text { broadband } \\
\text { stations }\end{array}$ & $\begin{array}{l}\text { Three-component } \\
\text { strong-motion } \\
\text { stations }\end{array}$ & $\begin{array}{l}\text { Infrasound } \\
\text { stations or } \\
\text { arrays }\end{array}$ \\
\hline 1988 & 25 & 29 & 23 & 2 & 0 & 0 & 0 \\
\hline 1989 & 28 & 32 & 26 & 2 & 0 & 0 & 0 \\
\hline 1990 & 42 & 49 & 39 & 3 & 0 & 0 & 0 \\
\hline 1991 & 36 & 42 & 33 & 3 & 0 & 0 & 0 \\
\hline 1992 & 39 & 46 & 36 & 3 & 0 & 0 & 0 \\
\hline 1993 & 44 & 51 & 41 & 3 & 0 & 0 & 1 \\
\hline 1994 & 47 & 58 & 42 & 5 & 0 & 0 & 2 \\
\hline 1995 & 57 & 67 & 52 & 5 & 0 & 0 & 2 \\
\hline 1996 & 60 & 79 & 49 & 10 & 1 & 0 & 3 \\
\hline 1997 & 92 & 125 & 83 & 12 & 2 & 0 & 4 \\
\hline 1998 & 108 & 142 & 94 & 14 & 2 & 0 & 4 \\
\hline 1999 & 121 & 156 & 106 & 14 & 2 & 0 & 4 \\
\hline 2000 & 125 & 162 & 108 & 16 & 2 & 0 & 4 \\
\hline 2001 & 138 & 177 & 120 & 17 & 3 & 0 & 4 \\
\hline 2002 & 140 & 179 & 124 & 16 & 2 & 0 & 4 \\
\hline 2003 & 160 & 217 & 135 & 18 & 9 & 0 & 4 \\
\hline 2004 & 182 & 255 & 149 & 20 & 15 & 0 & 4 \\
\hline 2005 & 188 & 266 & 151 & 23 & 15 & 0 & 4 \\
\hline 2006 & 190 & 275 & 154 & 23 & 15 & 1 & 6 \\
\hline 2007 & 193 & 281 & 154 & 22 & 17 & 1 & 6 \\
\hline 2008 & 193 & 281 & 154 & 22 & 17 & 1 & 6 \\
\hline 2009 & 196 & 291 & 155 & 22 & 19 & 1 & 6 \\
\hline 2010 & 200 & 303 & 155 & 22 & 23 & 1 & 8 \\
\hline 2011 & 201 & 319 & 158 & 22 & 29 & 1 & 8 \\
\hline 2012 & 202 & 326 & 155 & 22 & 32 & 1 & 9 \\
\hline 2013 & 204 & 338 & 155 & 22 & 36 & 1 & 9 \\
\hline 2014 & 207 & 356 & 156 & 23 & 41 & 1 & 10 \\
\hline 2015 & 211 & 377 & 156 & 23 & 48 & 1 & 10 \\
\hline 2016 & 211 & 400 & 147 & 26 & 55 & 1 & 13 \\
\hline 2017 & 212 & 419 & 146 & 26 & 62 & 1 & 16 \\
\hline
\end{tabular}

is estimated using IRIS's Gap/Overlap Analysis Tool (GOAT) (Stromme, 2000; appendix 3), are archived and available through the IRIS Data Management Center (https://ds.iris.edu/ $\mathrm{ds} /$ nodes/dmc/). All continuous data since 2002 are also available from AVO on a Winston server (https://volcanoes.usgs. gov/software/winston/index.shtml). Waveforms for all located events between October 12, 1989, and December 31, 2017, are contained within the AVO AQMS database.
Data from selected seismograph stations operated by the Alaska Earthquake Center (AEC; formerly the Alaska Earthquake Information Center, AEIC), Global Seismograph Network (GSN), Transportable Array (TA), and National Tsunami Warning Center (NTWC) were routinely used in event detection and location by AVO analysts. Station parameters for the AEIC, GSN, TA, and NTWC stations used by AVO are available from the respective agencies and IRIS. 
Table 3. Volcanic centers associated with each of the volcano seismic-monitoring subnetworks used by the Alaska Volcano Observatory.

[Seismic-monitoring networks are abbreviated from the volcanoes being monitored. See figure 1 for the location of the volcanoes.]

\begin{tabular}{|c|c|c|c|}
\hline Volcano subnetwork & Volcanoes monitored & Volcano subnetwork & Volcanoes monitored \\
\hline Akutan & Akutan Peak & Korovin & Korovin Volcano \\
\hline Aniakchak & Aniakchak Crater & Little Sitkin & Little Sitkin Volcano \\
\hline Cerberus & Mount Cerberus & Okmok & Okmok Caldera \\
\hline Cleveland & Mount Cleveland & Pavlof & Pavlof Volcano \\
\hline Iliamna & Iliamna Volcano & Shishaldin & Fisher Caldera, Isanotski Peaks, and \\
\hline Fourpeaked & Fourpeaked Mountain & & Shishaldin Volcano \\
\hline Gareloi & Mount Gareloi & Spurr & Mount Spurr \\
\hline Great Sitkin & Great Sitkin Volcano & Tanaga & Tanaga Volcano \\
\hline Kanaga & Kanaga Volcano & Ugashik-Peulik & Ugashik-Peulik Volcano and Ukinrek Maars \\
\hline
\end{tabular}

\section{Seismic-Velocity Models}

AVO currently uses 13 local volcano-specific seismicvelocity models and a regional seismic-velocity model to locate earthquakes at Alaskan volcanoes. All velocity models are one-dimensional models using horizontal layers to approximate the local seismic-velocity structure. Each model, with one exception, assumes a series of constant velocity layers. The single exception is the Akutan velocity model (Power and others, 1996), which has a velocity gradient in a layer overlying a half-space of constant velocity.

One or more vertical cylindrical volumes were used to model the volcanic-source zones for all volcanoes where a local velocity model was used. Earthquakes within these cylindrical volumes were located using a local model, and earthquakes outside of the cylindrical volumes were located using the regional model. The top of each cylinder was set at the summit elevation of the highest volcanic peak located within the cylinder zone, and the bottom was set at a depth of $50 \mathrm{~km}$ below sea level. Most cylindrical volumes had a radius of $20 \mathrm{~km}$ with the exception of the cylinders centered on Shishaldin and Mount Veniaminof. The cylinder centered on Shishaldin had a radius of $30 \mathrm{~km}$ to encompass Fisher Caldera and Isanotski Volcano. The cylinder centered on Mount Veniaminof also had a radius of $30 \mathrm{~km}$ because of the large size of the volcanic edifice. The maximum elevation for the regional model was set at $3.2 \mathrm{~km}$, the elevation of the highest volcano in the Aleutian arc.

The Akutan Peak, Augustine (Power, 1988), Iliamna (Roman and others, 2001), Makushin (Cheryl Searcy, USGS, written commun., 2010), Okmok Caldera (Masterlark and others, 2010), Tanaga (John Power, USGS, written commun., 2005), Mount Veniaminof (Sánchez, 2005), and Westdahl Peak (Dixon and others, 2005) velocity models were used to locate hypocenters that fell within cylindrical volumes described above, centered on each respective volcano. Five overlapping cylinders defined the volume in which the Mount Spurr velocity model (Jolly and others, 1994) was used, 4 overlapping cylinders defined the volume for the Redoubt Volcano velocity model (Lahr and others, 1994), and 4 overlapping cylinders defined the volume for the Mount Katmai model (Searcy, 2003). The Andreanof Islands velocity model, modified from that in Toth and Kisslinger (1984), was used to locate earthquakes within a volume defined by three cylinders centered on Kanaga Volcano, Mount Moffet (located near Adak), and Great Sitkin Volcano. The Cold Bay velocity model (McNutt and Jacob, 1986) was used to locate earthquakes that fell within cylindrical volumes centered on Mount Dutton, Pavlof Volcano, and Shishaldin Volcano. Earthquakes located at Fisher Caldera and Isanotski Volcano fell within the cylindrical volume centered on Shishaldin Volcano. Specific velocity models for the remaining monitored volcanoes were not available in the reporting period and the regional velocity model of Fogleman and others (1993) was used to locate earthquakes near these volcanoes. The regional velocity model and volcano-specific models used to locate earthquakes in this report are summarized in appendix 5 . The cylindrical model 
parameters and figures showing the volcanic-source zones modeled by multiple cylinders are shown in appendix 6 .

\section{Seismicity}

Between 2013 and 2017, AVO located 28,172 earthquakes, an average of 5,634 earthquakes per year $(3,840$ in $2013,5,819$ in $2014,5,297$ in 2015, 6,151 in 2016, and 7,065 in 2017) at 34 volcanic centers with seismograph subnetworks (fig. 4, appendix 1). Of the earthquakes located in 2013-17, 82 percent $(4,628$ earthquakes per year) were located within
$20 \mathrm{~km}$ of a monitored volcanic center. The numbers of located earthquakes associated with volcanic centers for 2013-17 are shown in table 4. The numbers of located earthquakes in the AVO catalog by year are shown in figure 4 and table 5. A summary file of origin times, hypocenters, magnitudes, and location quality statistics for earthquakes located in 2013-17 is included in a data supplement to this report with data headers described in appendix 7.

Using the AVO earthquake catalog from the period in which an Earthworm based system was used for event detection (2002-17), the magnitude of completeness $\left(M_{\mathrm{c}}\right)$ for each subnetwork was calculated (table 4$). M_{\mathrm{c}}$ is the magnitude threshold above which we are reasonably certain that an event

Table 4. Number of earthquakes located by the Alaska Volcano Observatory within 20 kilometers of monitored volcanic centers in in 2013-17.

[Volcano names used for seismic-monitoring subnetworks are abbreviated; see figure 1 for complete names. $\mathbf{M}^{\mathrm{c}}$, magnitude of completeness for Alaska Volcano Observatory seismograph subnetworks during the period March 2002-December 2017; --, not enough data to calculate a $\mathrm{M}_{\mathrm{c}}$ ]

\begin{tabular}{|c|c|c|c|c|c|c|}
\hline Volcano subnetwork & $\begin{array}{l}\text { Earthquakes } \\
\text { located in } 2013\end{array}$ & $\begin{array}{c}\text { Earthquakes } \\
\text { located in } 2014\end{array}$ & $\begin{array}{c}\text { Earthquakes } \\
\text { located in } 2015\end{array}$ & $\begin{array}{l}\text { Earthquakes } \\
\text { located in } 2016\end{array}$ & $\begin{array}{c}\text { Earthquakes } \\
\text { located in } 2017\end{array}$ & $\mathbf{M}_{\mathrm{c}}$ \\
\hline Akutan & 147 & 293 & 117 & 238 & 228 & 0.3 \\
\hline Aniakchak & 48 & 0 & 1 & 35 & 60 & 0.1 \\
\hline Augustine & 102 & 125 & 162 & 836 & 367 & 0.1 \\
\hline Cerberus & 0 & 1,722 & 903 & 57 & 96 & 0.5 \\
\hline Cleveland & -- & 1 & 1 & 1 & 1 & -- \\
\hline Dutton & 11 & 4 & 1 & 12 & 1 & 1.0 \\
\hline Fourpeaked & 77 & 1 & 0 & 1 & 33 & 0.7 \\
\hline Gareloi & 10 & 4 & 20 & 262 & 268 & 1.2 \\
\hline Great Sitkin & 77 & 18 & 24 & 100 & 764 & 0.4 \\
\hline Iliamna & 443 & 28 & 8 & 4 & 18 & -0.2 \\
\hline Kanaga & 143 & 143 & 57 & 127 & 53 & 1.2 \\
\hline Katmai-North & 111 & 129 & 179 & 193 & 139 & 0.8 \\
\hline Katmai-Central & 162 & 297 & 497 & 310 & 852 & 0.4 \\
\hline Katmai-South & 223 & 381 & 454 & 139 & 323 & 0.3 \\
\hline Korovin & 186 & 282 & 108 & 114 & 114 & 0.5 \\
\hline Little Sitkin & 3 & 38 & 115 & 32 & 39 & 0.0 \\
\hline Makushin & 458 & 413 & 707 & 692 & 857 & 0.5 \\
\hline Okmok & 39 & 42 & 45 & 27 & 32 & 0.8 \\
\hline Pavlof & 9 & 25 & 18 & 11 & 29 & 1.0 \\
\hline Redoubt & 189 & 96 & 173 & 170 & 195 & 0.4 \\
\hline Shishaldin & 3 & 18 & 33 & 38 & 32 & 0.6 \\
\hline Spurr & 330 & 577 & 513 & 1,686 & 747 & 0.2 \\
\hline Tanaga & 98 & 145 & 85 & 72 & 462 & 1.1 \\
\hline Ugashik-Peulik & 19 & 36 & 9 & 7 & 7 & 0.9 \\
\hline Veniaminof & 7 & 18 & 0 & 0 & 33 & 1.1 \\
\hline Westdahl & 22 & 12 & 53 & 96 & 67 & 1.1 \\
\hline Wrangell & 0 & 0 & 0 & 0 & 16 & 0.9 \\
\hline Totals & 2,917 & 4,848 & 4,283 & 5,260 & 5,833 & -- \\
\hline
\end{tabular}




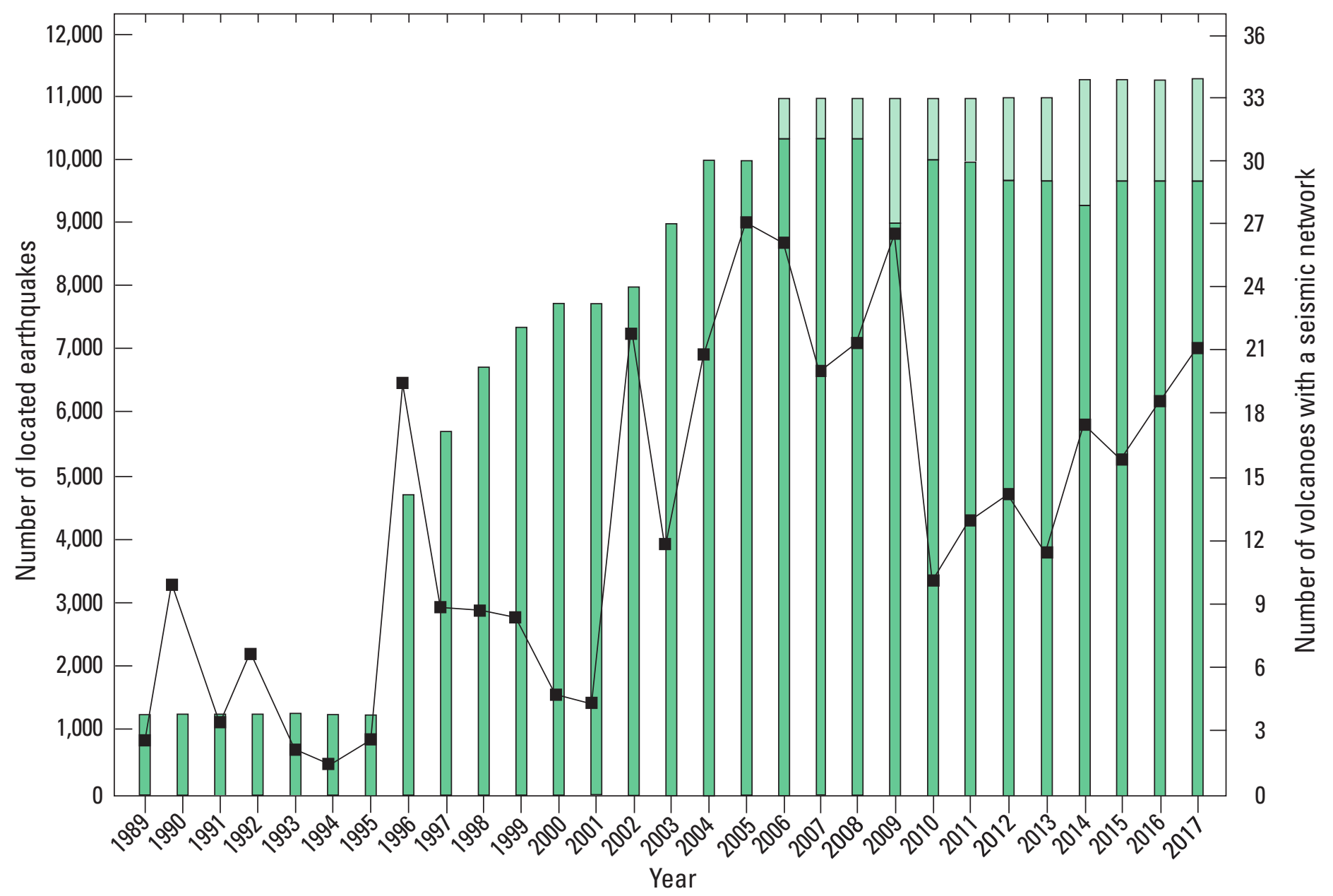

Figure 4. Number of earthquakes located per year in the Alaska Volcano Observatory earthquake catalog, 1989-2017 (black line), and number of volcanoes with a seismograph network per year (green bars). The lighter green color indicates the number of volcanoes with seismograph networks that are not included on the formal list of monitored volcanoes.

Table 5. Number of earthquakes located per year in the Alaska Volcano Observatory (AVO) earthquake catalog, 1989-2017.

\begin{tabular}{cccc}
\hline Year & $\begin{array}{c}\text { Number of earthquakes } \\
\text { located per year }\end{array}$ & $\begin{array}{c}\text { Number of earthquakes located per } \\
\text { year within 20 kilometers of a monitored } \\
\text { volcano }\end{array}$ & $\begin{array}{c}\text { Volcanoes with an AV0 seismograph } \\
\text { network }\end{array}$ \\
\hline 1989 & 911 & 892 & 4 \\
1990 & 3,285 & 3,148 & 4 \\
1991 & 1,119 & 1,064 & 4 \\
1992 & 2,184 & 2,104 & 4 \\
1993 & 697 & 592 & 4 \\
1994 & 441 & 407 & 4 \\
1995 & 850 & 760 & 4 \\
1996 & 6,466 & 4,259 & 14 \\
1997 & 2,930 & 1,783 & 17 \\
1998 & 2,873 & 1,886 & 20 \\
1999 & 2,769 & 2,343 & 22 \\
2000 & 1,551 & 1,225 & 22
\end{tabular}


Table 5. Number of earthquakes located per year in the Alaska Volcano Observatory (AVO) earthquake catalog, 1989-2017.Continued

\begin{tabular}{cccc}
\hline Year & $\begin{array}{c}\text { Number of earthquakes } \\
\text { located per year }\end{array}$ & $\begin{array}{c}\text { Number of earthquakes located per } \\
\text { year within 20 kilometers of a monitored } \\
\text { volcano }\end{array}$ & $\begin{array}{c}\text { Volcanoes with an AV0 seismograph } \\
\text { network }\end{array}$ \\
\hline 2001 & 1,427 & 1,122 & 23 \\
2002 & 7,242 & 6,578 & 24 \\
2003 & 3,911 & 3,264 & 27 \\
2004 & 6,928 & 6,105 & 30 \\
2005 & 9,012 & 8,146 & 32 \\
2006 & 8,666 & 7,782 & 33 \\
2007 & 6,664 & 5,660 & 33 \\
2008 & 7,097 & 5,318 & 33 \\
2009 & 8,829 & 7,438 & 33 \\
2010 & 3,405 & 2,846 & 33 \\
2011 & 4,364 & 3,651 & 33 \\
2012 & 4,791 & 4,188 & 33 \\
2013 & 3,840 & 2,917 & 33 \\
2014 & 5,819 & 4,848 & 34 \\
2015 & 5,297 & 4,283 & 34 \\
2016 & 6,151 & 5,260 & 34 \\
2017 & 7,065 & 5,833 & 34 \\
\hline
\end{tabular}

of magnitude $M_{\mathrm{c}}$ or greater was detected. The $M_{\mathrm{c}}$ was determined using a maximum likelihood estimate of the inflection point in the frequency magnitude distribution using the seismology analysis software ZMAP (Wiemer, 2001). The $M_{\mathrm{c}}$ ranged from -0.2 to 1.2 for the individual subnetworks.

A summary of notable events located in the years covered by this AVO earthquake catalog were presented in past publications (appendix 8). Because a description of the AVO seismograph network is no longer an annual publication, notable seismic activity is included in the AVO annual summaries. Table 6 summarizes the notable seismic activity presented in detail in the annual AVO summaries of volcanic activity with references for the AVO summaries that cover the reporting period of this report in table 7 .

Table 6. Summary of notable seismic activity at Alaskan volcanoes for 2013-17.

[Details can be found in the Alaska Volcano Observatory annual summaries of volcanic activity in Alaska referenced in table 7]

\begin{tabular}{lll}
\hline \multicolumn{1}{c}{ Volcano } & \multicolumn{1}{c}{ Period of activity } & \multicolumn{1}{c}{ Type of activity } \\
\hline Akutan Volcano & January 2013 & \multicolumn{1}{c}{ Triggered seismicity } \\
& July 2014 & Earthquake swarm \\
Aniakchak Crater & Intermittent in 2013 & Earthquake swarm \\
Augustine Volcano & February 2016-December 2017 & Earthquake swarm \\
Bogoslof Island & December 2016-December 2017 & Eruption \\
Mount Cerberus & June 2014 & Earthquake swarm \\
& January-May 2015 & Earthquake swarm \\
Mount Cleveland & Intermittent 2013-17 & Explosions \\
Fourpeaked Mountain & April-May 2013 & Seismic unrest \\
& September-October, 2016 & Earthquake swarm \\
Mount Gareloi & July-August 2013 & Felt earthquakes \\
Great Sitkin Volcano & July-August 2013 & Earthquake Swarm \\
& January, July 2017 & Earthquake swarms
\end{tabular}


Table 6. Summary of notable seismic activity at Alaskan volcanoes for 2013-17. - Continued

[Details can be found in the Alaska Volcano Observatory annual summaries of volcanic activity in Alaska referenced in table 7]

\begin{tabular}{|c|c|c|}
\hline Volcano & Period of activity & Type of activity \\
\hline Iliamna Volcano & July 2015 & Large tectonic earthquake \\
\hline Kanaga Volcano & March 2014 & Earthquake swarm \\
\hline $\begin{array}{l}\text { Mount Katmai/ Mount } \\
\text { Martin }\end{array}$ & October 2014 & Earthquake swarm \\
\hline Korovin Volcano & April-August 2016 & Tremor \\
\hline Makushin Volcano & Intermittent $2013-17$ & Earthquake swarms, tremor \\
\hline Okmok Caldera & $\begin{array}{l}\text { March, September, and October } 2013 \\
\text { Intermittent in } 2013 \\
\text { September } 2016\end{array}$ & $\begin{array}{l}\text { Earthquake swarms } \\
\text { Tremor } \\
\text { Tremor }\end{array}$ \\
\hline Pavlof Volcano & $\begin{array}{l}\text { May-August } 2013 \\
\text { May-June } 2014 \\
\text { November 2014-January } 2015 \\
2016\end{array}$ & $\begin{array}{l}\text { Eruption } \\
\text { Eruption } \\
\text { Eruption } \\
\text { Eruption }\end{array}$ \\
\hline Mount Recheshnoi & Intermittent 2013-17 & Earthquake swarm \\
\hline Shishaldin Volcano & $\begin{array}{l}\text { January } 2013 \\
\text { March 2014-December } 2017\end{array}$ & $\begin{array}{l}\text { Increased seismicity } \\
\text { Small eruptions }\end{array}$ \\
\hline Mount Spurr & $\begin{array}{l}\text { June and September } 2014 \\
\text { October-December } 2015 \\
\text { Throughout 2015-17 } \\
\text { June-July } 2016\end{array}$ & $\begin{array}{l}\text { Earthquake swarm } \\
\text { Earthquake swarm } \\
\text { Earthquake swarm } \\
\text { Earthquake swarm }\end{array}$ \\
\hline Tanaga Volcano & February-August 2014 & Earthquake swarm \\
\hline Ugashik-Peulik Volcano & March 2015 & Large tectonic earthquake \\
\hline Mount Veniaminof & $\begin{array}{l}\text { June 2013-January } 2015 \\
\text { September-December } 2015\end{array}$ & $\begin{array}{l}\text { Effusive eruption } \\
\text { Seismic unrest }\end{array}$ \\
\hline
\end{tabular}

Table 7. Alaska Volcano Observatory Annual Summary reports for 2013-2015.

[Summary reports for 2016 and 2017 are not yet published]

\begin{tabular}{cc}
\hline Year & Report citation \\
\hline 2013 & Dixon, J.P., Cameron, C.E., McGimsey, R.G., Neal, C.A., and Waythomas, C.F., 2015, 2013 Volcanic activity in \\
& Alaska—Summary of events and response of the Alaska Volcano Observatory: U.S. Geological Survey Scientific \\
& Investigations Report 2015-5110, 92 p., https://dx.doi.org/10.3133/sir20155110. \\
& Cameron, C.E., Dixon, J.P., Neal, C.A., Waythomas, C.F., Schaefer, J.R., and McGimsey, R.G., 2017, 2014 Volcanic \\
& activity in Alaska-Summary of events and response of the Alaska Volcano Observatory: U.S. Geological Survey \\
& Scientific Investigations Report 2017-5077, 81 p., https://doi.org/10.3133/sir20175077. \\
& Dixon, J.P., Cameron, C.E., Iezzi, A.M., and Wallace, K., 2017, 2015 Volcanic activity in Alaska—Summary of \\
& events and response of the Alaska Volcano Observatory: U.S. Geological Survey Scientific Investigations Report \\
& 2017-5104, 81 p., https://doi.org/10.3133/sir20175104. \\
\hline
\end{tabular}




\section{Summary}

Between January 1, 2013, and December 31, 2017, AVO located 28,172 earthquakes or an average of 5,634 earthquakes per year, of which an average of 4,628 occurred within $20 \mathrm{~km}$ of the 34 volcanoes with seismograph subnetworks. There was significant seismic activity at 22 volcanoes in 2013-17 (Akutan Peak, Aniakchak Crater, Augustine, Bogoslof Island, Mount Cerberus, Mount Cleveland, Fourpeaked Mountain, Mount Gareloi, Great Sitkin, Ilimana, Kanaga, Korovin, Makushin, Martin, Okmok Caldera, Pavlof, Mount Recheshnoi, Shishaldin, Mount Spurr, Tanaga, Ugashik-Peulik, and Mount Veniaminof). Instrumentation highlights for 2013-17 were the establishment of two seismograph and infrasound stations near Mount Cleveland, the start of a transition from analog to digital telemetry, and increased number of broadband seismometers and infrasound sensors. The operational highlight was the return of seismic monitoring at Korovin and Ugashik-Peulik Volcanoes and their return to the seismic monitored list following network repairs. This catalog includes locations, magnitudes, and statistics of the earthquakes located in 2013-17.

Earthquake epicenters at volcanic centers located in 2013-17 with the AVO seismograph network are shown in appendix 1. Locations for all AVO stations are contained in appendix 2 with maps showing the locations of stations with respect to individual volcanoes in appendix 1. Each station's operational status for the catalog period is shown in appendixes 3 and 4. Included with this report is a list of earthquakes located in 2013-17 in which a description of the data in the summary listing is in appendix 7. Previous AVO earthquake catalogs are listed in appendix 8. Selected papers that used data from the AVO seismograph and infrasound networks are listed in appendix 9.

Available for download with this report is a data supplement (available only online at https://doi.org/10.3133/ds1115) that is a compressed file containing a summary listing of earthquake hypocenters and a metadata file in the form of a dataless SEED volume for the AVO seismograph network. Continuous waveform data for the majority of AVO seismograph stations, whose availability is displayed using IRIS's Gap/Overlap Analysis Tool (appendix 3), are archived and available through IRIS (http://www.iris.edu/). Archives of waveform data are also maintained at AVO offices.

\section{References Cited}

Cameron, C.E., and Schaefer, J.R., 2016, Historically active volcanoes of Alaska: Alaska Division of Geological \& Geophysical Surveys Miscellaneous Publication 133, v. 2, 1 sheet, scale 1:3,000,000, https://doi.org/10.14509/20181.
Cameron, C.E., Dixon, J.P., Neal, C.A., Waythomas, C.F., Schaefer, J.R., and McGimsey, R.G., 2017, 2014 Volcanic activity in Alaska - Summary of events and response of the Alaska Volcano Observatory: U.S. Geological Survey Scientific Investigations Report 2017-5077, 81 p., https://doi. org/10.3133/sir20175077.

Dixon, J.P., Power, J.A., and Stihler, S.D., 2005, Seismic observations of Westdahl Volcano and Western Unimak Island, Alaska-1999-2005: EOS, Transactions American Geophysical, v. 86, no. 52, fall meeting supplement, abstract S11B-0169.

Dixon, J.P., Cameron, C.E., McGimsey, R.G., Neal, C.A., and Waythomas, C.F., 2015, 2013 Volcanic activity in AlaskaSummary of events and response of the Alaska Volcano Observatory: U.S. Geological Survey Scientific Investigations Report 2015-5110, 92 p., https://doi.org/10.3133/ $\operatorname{sir} 20155110$.

Dixon, J.P., Cameron, C.E., Iezzi, A.M., and Wallace, K., 2017, 2015 Volcanic activity in Alaska-Summary of events and response of the Alaska Volcano Observatory: U.S. Geological Survey Scientific Investigations Report 2017-5104, 61 p., https://doi.org/10.3133/sir20175104.

Fogleman, K.A., Lahr, J.C., Stephens, C.D., and Page, R.A., 1993, Earthquake locations determined by the southern Alaska seismograph network for October 1971 through May 1989: U.S. Geological Survey Open-File Report 93-309, 54 p., https://doi.org/10.3133/ofr93309.

Johnson, C.E., Bittenbinder, A., Bogaert, D., Dietz, L., and Kohler, W., 1995, Earthworm-A flexible approach to seismograph network processing: Incorporated Research Institutions for Seismology Newsletter, v. 14, no. 2, p. 1-4.

Jolly, A.D., Page, R.A., and Power, J.A., 1994, Seismicity and stress in the vicinity of Mt. Spurr volcano, south-central Alaska: Journal of Geophysical Research, v. 99, no. B8, p. 15305-15318, https://doi.org/10.1029/94JB00136.

Haney, M.M., Power, J.A., West, M., and Michaels, P., 2012, Causal instrument corrections for short-period and broadband seismometers: Seismological Research Letters, v. 83, no. 5, p. 834-845, https://doi.org/10.1785/0220120031.

Hauksson, E., Jones, L.M., and Shakal, A., 2003, TriNet-A modern ground motion seismic network, in Jennings, $\mathrm{P}$, Kanamori, H., and Lee, W., eds., International handbook of earthquake and engineering seismology, vol. 81B: International Association of Seismology and Physics of the Earth's Interior centennial publication, p. 1275-1284.

International Federation of Digital Seismograph Networks, 2012, SEED reference manual - Standard for the Exchange of Earthquake Data, version 2.4: International Federation of Digital Seismograph Networks, 224 p., accessed April 9, 2019, at https://www.fdsn.org/seed_manual/SEEDManual_V2.4.pdf. 
Klein, F.W., 2002, User's Guide to HYPOINVERSE-2000, a Fortran program to solve for earthquake locations and magnitudes, U.S. Geological Survey Open-File Report 02-171, 123 p., https://doi.org/10.3133/ofr02171.

Lahr, J.C., Chouet, B.A., Stephens, C.D., Power, J.A., and Page, R.A., 1994, Earthquake classification, location, and error analysis in a volcanic environment-Implications for the magmatic system of the 1989-90 eruptions at Redoubt Volcano, Alaska: Journal of Volcanology and Geothermal Research, v. 62, no. 1-4, p. 137-151, https://doi. org/10.1016/0377-0273(94)90031-0.

Masterlark, T., Haney, M., Dickinson, H., Fournier, T., and Searcy, C.K., 2010, Rheological and structural controls on the deformation of Okmok Volcano, AlaskaFEMs, InSAR, and ambient noise tomography: Journal of Geophysical Research. v. 115, no. B2, https://doi. org/10.1029/2009JB006324.

McChesney, P.J., 1999, McVCO handbook 1999: U.S. Geological Survey Open-File Report 99-361, 51 p., https://doi. org/10.3133/ofr99361.

McNutt, S.R., and Jacob, K.H, 1986, Determination of largescale velocity structure of the crust and upper mantle in the vicinity of Pavlof Volcano, Alaska: Journal of Geophysical Research, v. 91, no. B5, p. 5013-5022., https://doi. org/10.1029/JB091iB05p05013.

Power, J.A., 1988, Seismicity associated with the 1986 eruption of Augustine Volcano, Alaska: Fairbanks, University of Alaska Fairbanks, Master's thesis, 149 p.

Power, J.A., Paskievitch, J.F., Richter, D.H., McGimsey, R.G., Stelling, P., Jolly, A.D., and Fletcher, H.J., 1996, 1996 seismicity and ground deformation at Akutan Volcano, EOS, Transactions American Geophysical Union, v. 77, no. 46, fall meeting supplement, p. 514.
Power, J.A., Friberg, P.A., Haney, M.M., Parker, T., Stihler, S.D., and Dixon, J.P., 2019, A unified catalog of earthquake hypocenters and magnitudes at volcanoes in Alaska-1989 to 2018: U.S. Geological Survey Scientific Investigations Report 2019-5037, 17 p., https://doi.org/10.3133/ sir20195037.

Rogers, J.A., Maslak, S., Lahr, J.C., 1980, A seismic electronic system with automatic calibration and crystal reference: U.S. Geological Survey Open-File Report 80-324, 48 p.

Roman, D.C., Power, J.A., Moran, S.C., Cashman, K.V., and Stihler, S.D., 2001, Unrest at Iliamna Volcano, Alaska in 1996-Evidence for a magmatic intrusion: EOS, Transactions American Geophysical Union, v. 82, no. 47, fall meeting supplement, p. 1329.

Sánchez, J.J., 2005, Volcano seismology from around the World - Case studies from Mount Pinatubo (Philippines), Galeras (Columbia), Mount Wrangell and Mount Veniaminof (Alaska): Fairbanks, University of Alaska Fairbanks, Ph.D. dissertation, $208 \mathrm{p}$.

Stromme, S., 2000, Gap/Overlap Analysis Tool (GOAT): Incorporated Research Institutions for Seismology DMS Newsletter, v. 2, no. 1 .

Searcy, C.K., 2003, Station corrections for the Katmai Region seismograph network: U.S. Geological Survey Open-File Report 03-403, 16 p., https://doi.org/10.3133/ofr03403.

Toth, T., and Kisslinger, C., 1984, Revised focal depths and velocity model for local earthquakes in the Adak seismic zone: Bulletin of the Seismological Society of America, v. 74, no. 4, p. 1349-1360.

U.S. Geological Survey, 2018, Jiggle-A graphical earthquake analysis tool: U.S. Geological Survey web page, accessed October 1, 2018, at http://pasadena.wr.usgs.gov/jiggle/.

Wiemer, S., 2001, A software package to analyze seismicity-ZMAP: Seismological Research Letters, v. 72, no. 3, p. 373-382, https://doi.org/10.1785/gssrl.72.3.373. 


\section{Appendix 1. Maps of Monitored Volcanoes with Earthquake Hypocenters in 2013-17}

The location of earthquake hypocenters and the seismograph stations used by the Alaska Volcano Observatory to locate earthquakes by seismograph subnetwork, showing their relation to the monitored volcanic centers, are included in appendix 1. The seismograph subnetwork that covers the Katmai volcanic cluster is broken into two figures, one covering the northern end of the group and the other the southern end. 


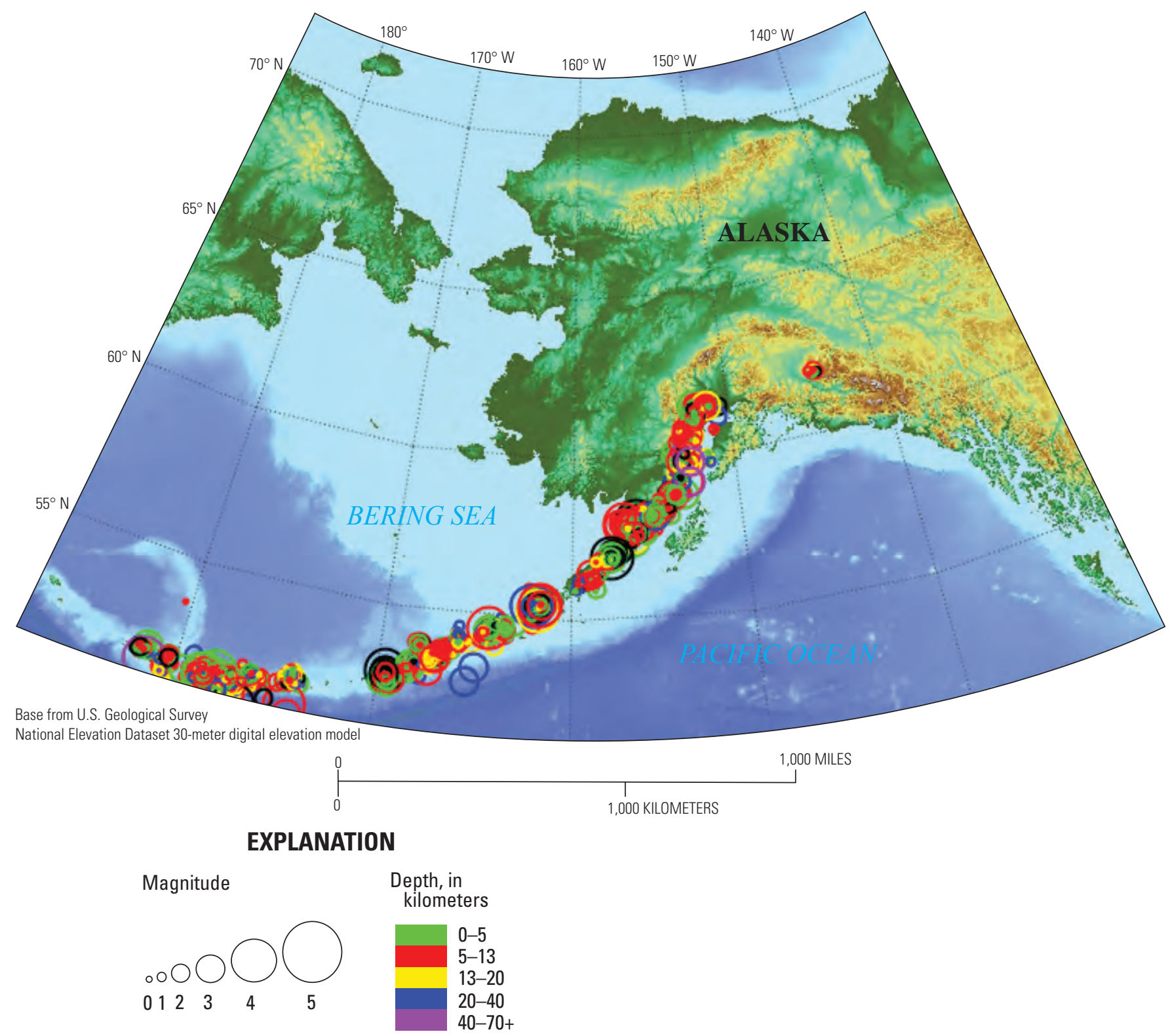

Figure 1.1. Map of Alaska showing all earthquakes (open circles) located by the Alaska Volcano Observatory in 2013-17. Earthquakes are scaled by magnitude and the color of the symbols varies with depth. 


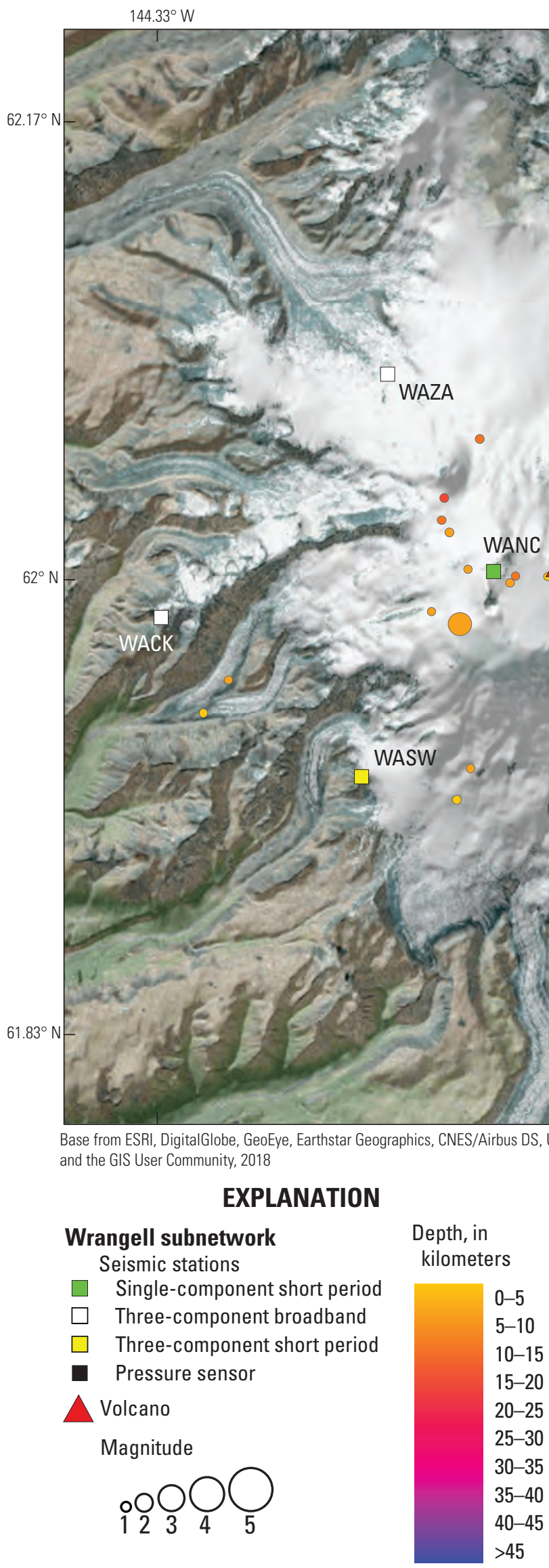

$144^{\circ} \mathrm{W}$

$143.67^{\circ} \mathrm{W}$

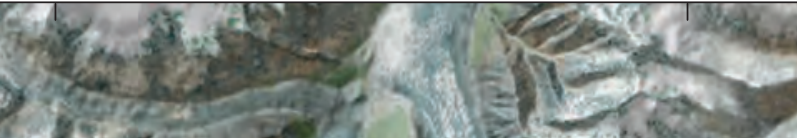




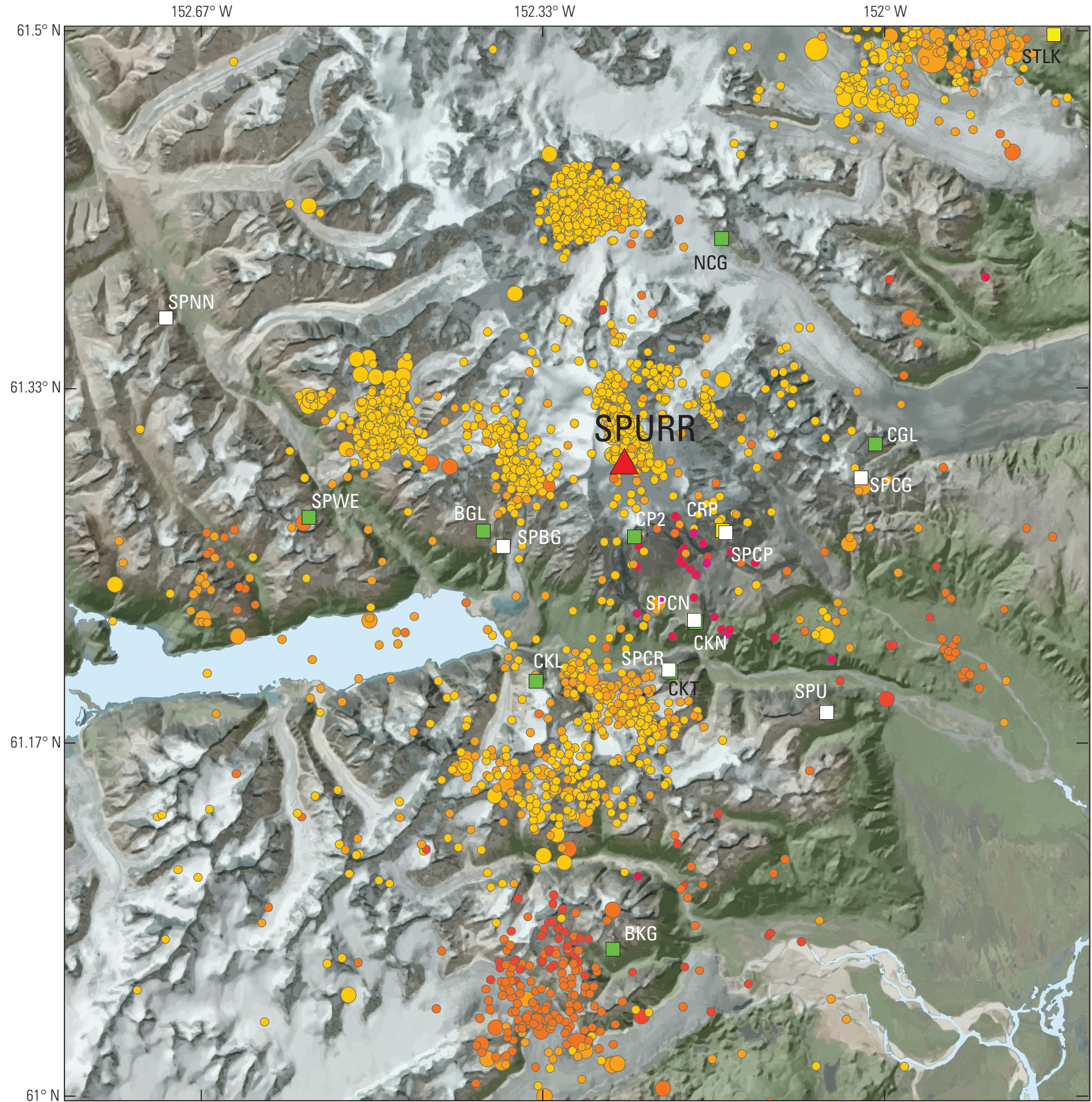

Base from ESRI, DigitalGlobe, GeoEye, Earthstar Geographics, CNES/Airbus DS, USDA, USGS, AeroGRID, IGN, and the GIS User Community, 2018

\section{EXPLANATION}

\section{Spurr subnetwork}

Seismic stations

$\square \quad$ Single-component short period

$\square \quad$ Three-component broadband

$\square \quad$ Three-component short period

- Pressure sensor

Volcano

Magnitude

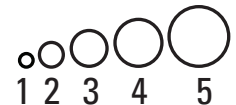

Depth, in

kilometers

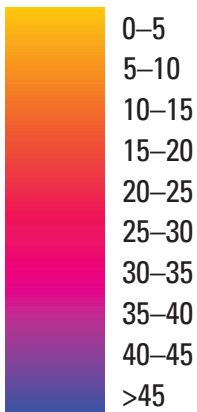

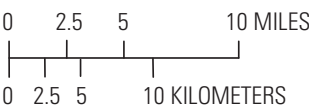

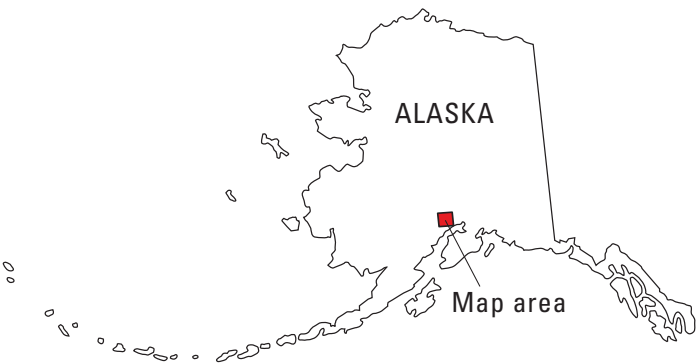

Figure 1.3. Map showing summary plot of earthquakes located by the Alaska Volcano Observatory with the seismicmonitoring subnetwork at Mount Spurr in 2013-17. 


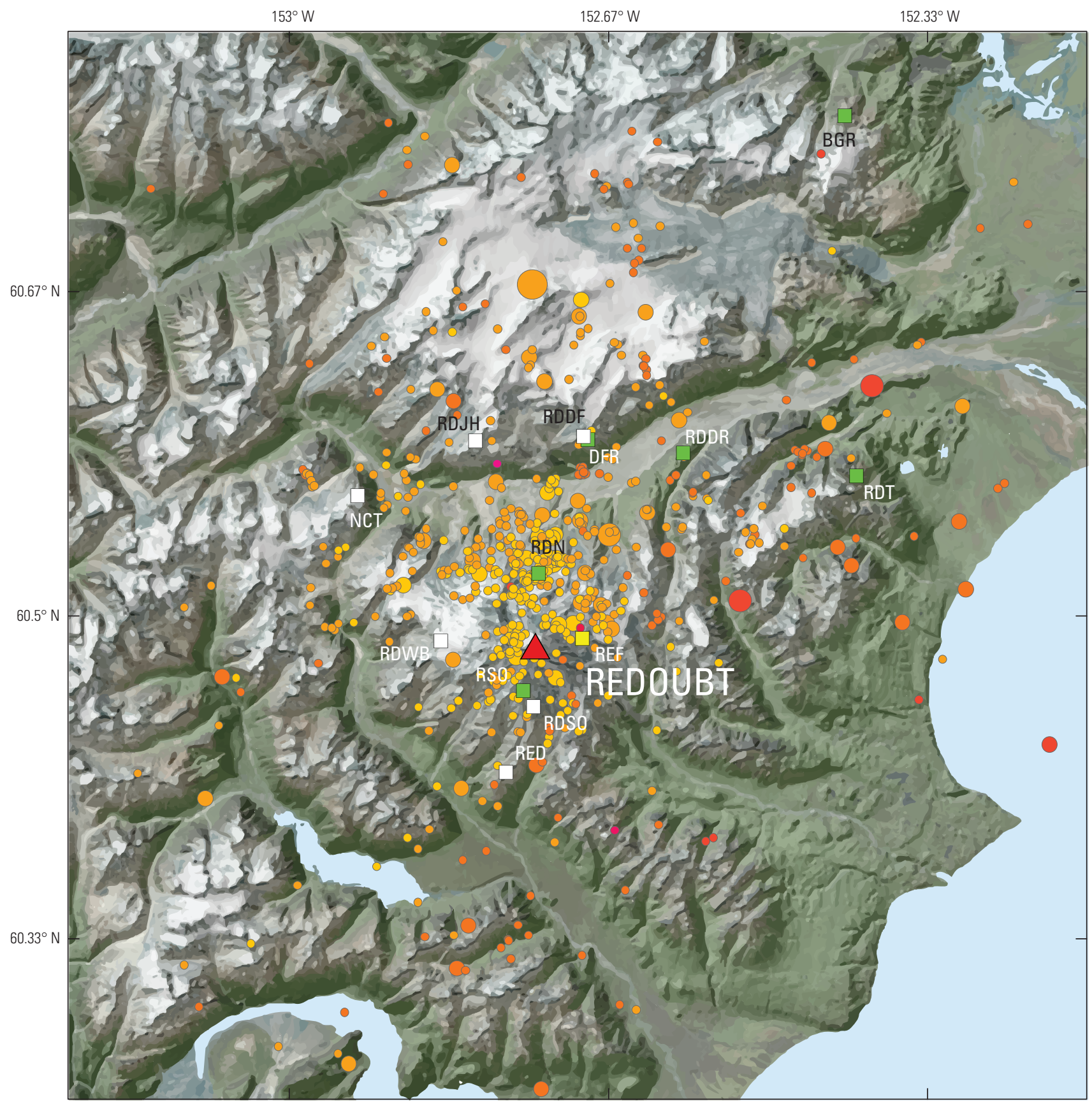

Base from ESRI, DigitalGlobe, GeoEye, Earthstar Geographics, CNES/Airbus DS, USDA, USGS, AeroGRID, IGN and the GIS User Community, 2018

\section{EXPLANATION}

\section{Redoubt subnetwork}

Seismic stations

$\square$ Single-component short period

$\square \quad$ Three-component broadband

$\square \quad$ Three-component short period

- Pressure sensor

Volcano

Magnitude

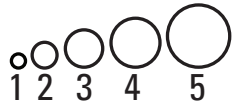

Depth, in

kilometers

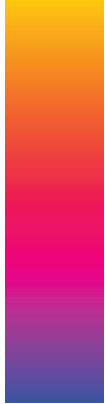

$5-10$

$10-15$

$15-20$

$20-25$

25-30

$30-35$

$35-40$

$40-45$

$>45$
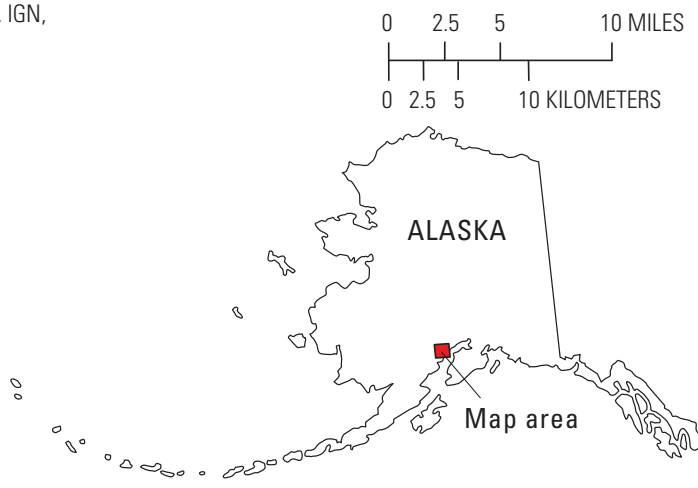

Figure 1.4. Map showing summary plot of earthquakes located by the Alaska Volcano Observatory with the seismic-monitoring subnetwork at Redoubt Volcano in 2013-17. 


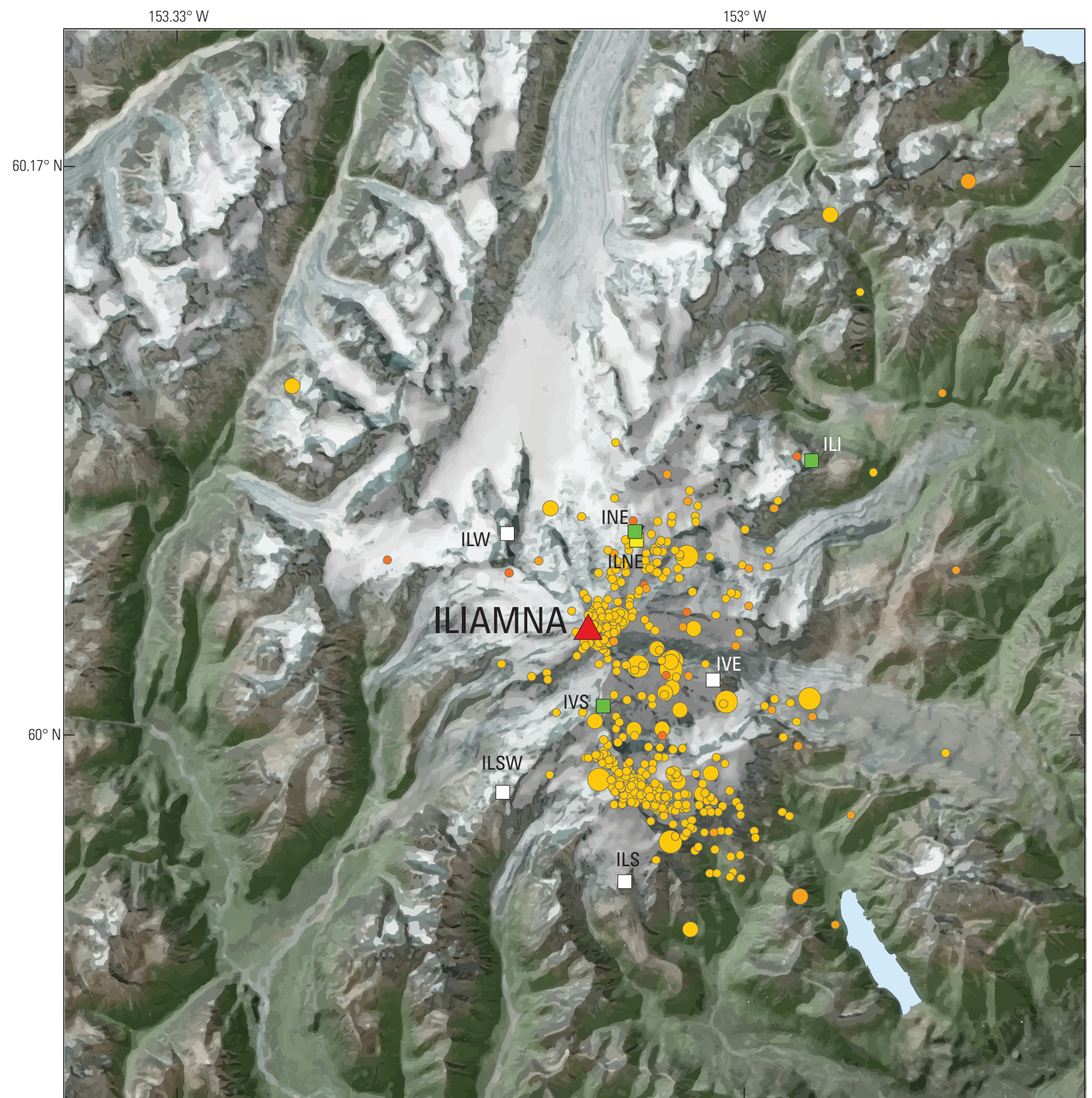

Base from ESRI, DigitalGlobe, GeoEye, Earthstar Geographics, CNES/Airbus DS, USDA, USGS, AeroGRID, IGN, and the GIS User Community, 2018

\section{EXPLANATION}

\section{Iliamna subnetwork}

Seismic stations

$\square \quad$ Single-component short period

$\square \quad$ Three-component broadband

$\square \quad$ Three-component short period

- Pressure sensor

$\triangle$ Volcano

Magnitude

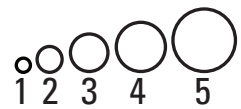

Depth, in

kilometers

$0-5$

5-10

$10-15$

$15-20$

20-25

25-30

30-35

35-40

$40-45$ $>45$
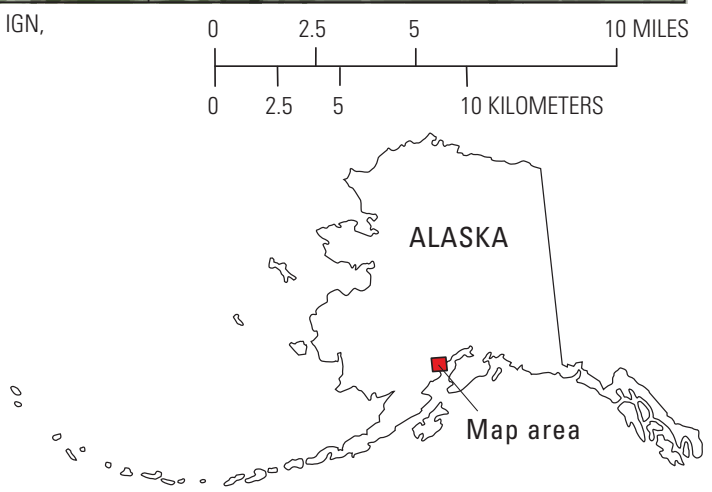

Figure 1.5. Map showing summary plot of earthquakes located by the Alaska Volcano Observatory with the seismic-monitoring subnetwork at lliamna Volcano in 2013-17. 


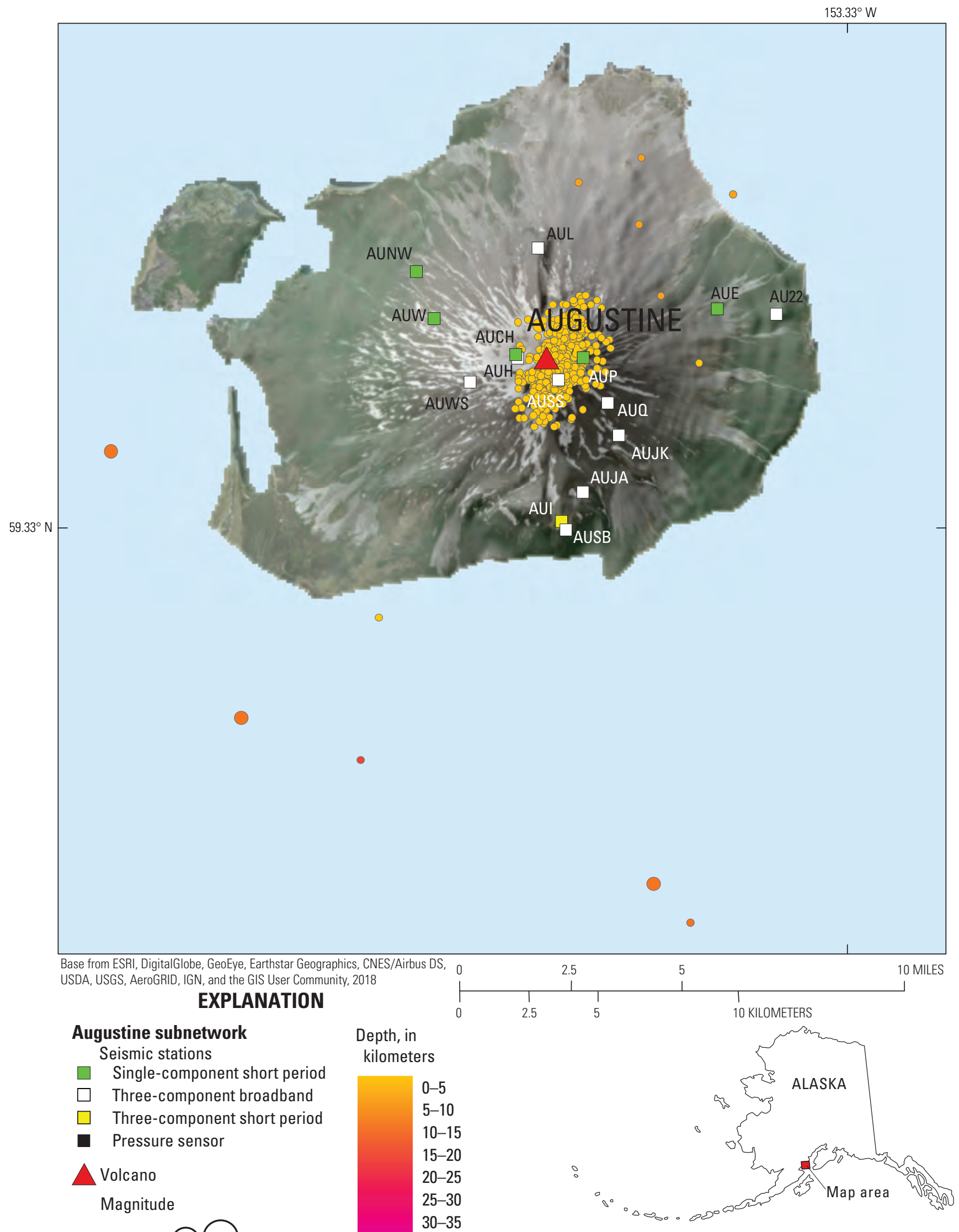

Figure 1.6. Map showing summary plot of earthquakes located by the Alaska Volcano Observatory with the seismic-monitoring subnetwork at Augustine Volcano in 2013-17. 


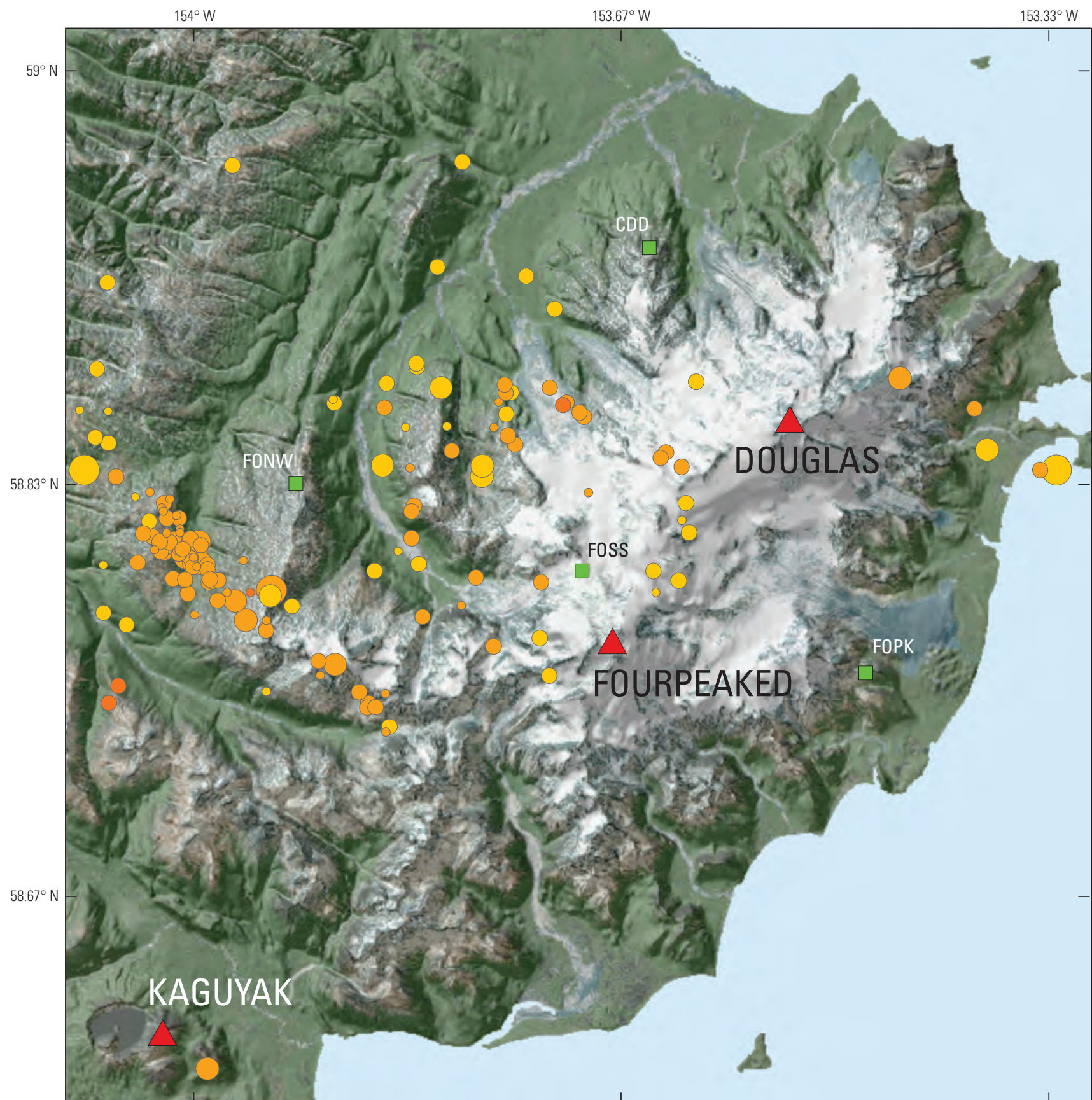

Base from ESRI, DigitalGlobe, GeoEye, Earthstar Geographics, CNES/Airbus DS, USDA, USGS, AeroGRID, IGN and the GIS User Community, 2018

\section{EXPLANATION}

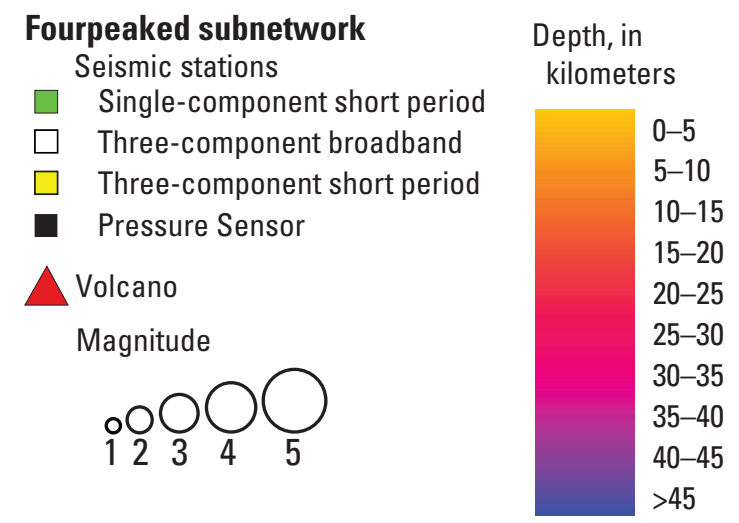

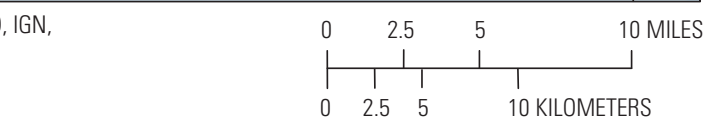




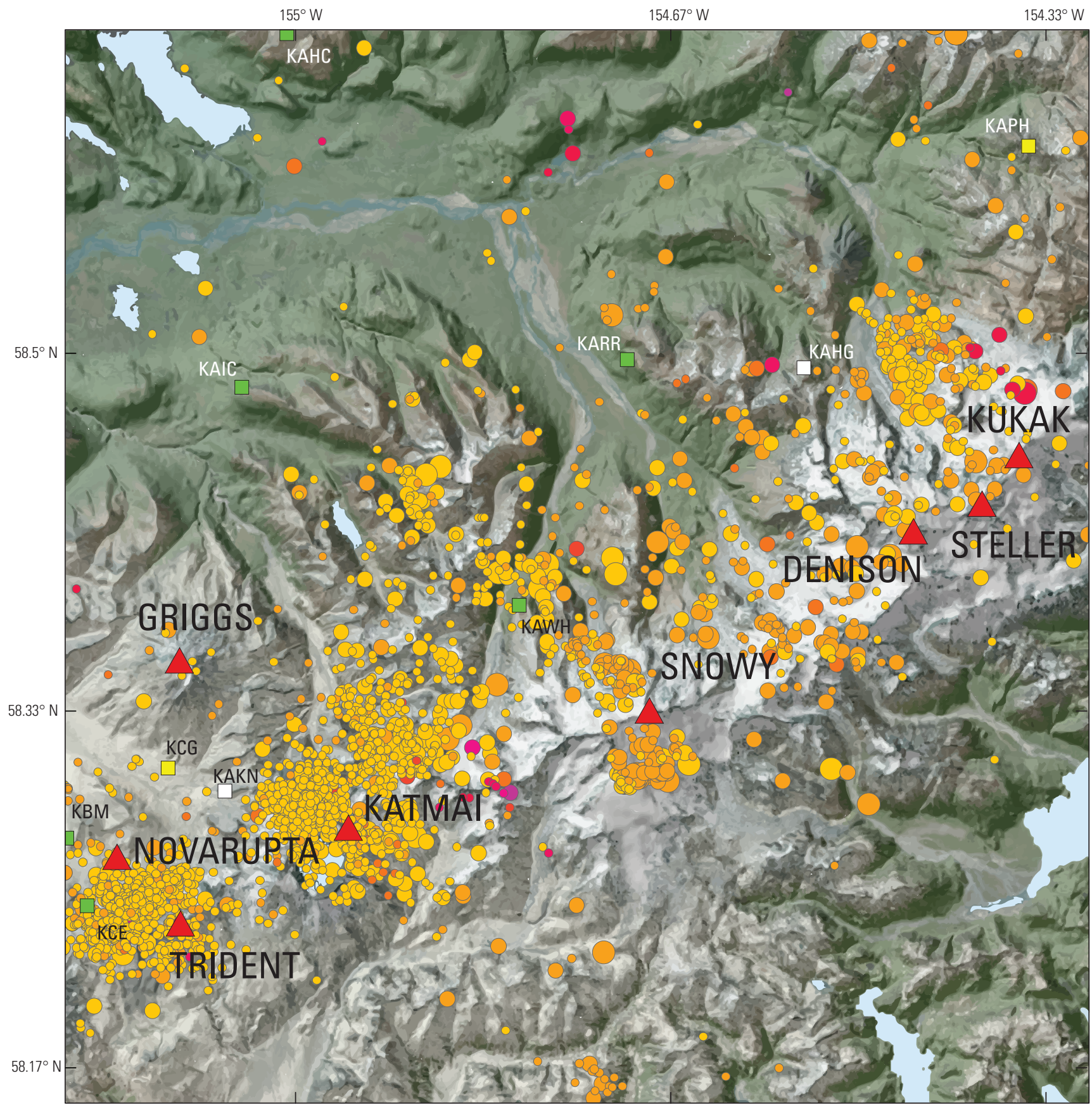

Base from ESRI, DigitalGlobe, GeoEye, Earthstar Geographics, CNES/Airbus DS, USDA, USGS, AeroGRID, IGN, and the GIS User Community, 2018

\section{EXPLANATION}

\section{Northern part of Katmai subnetwork}

Seismic stations

$\square \quad$ Single-component short period

$\square \quad$ Three-component broadband

$\square \quad$ Three-component short period

- Pressure sensor

Volcano

Magnitude

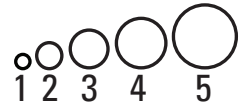

Depth, in

kilometers

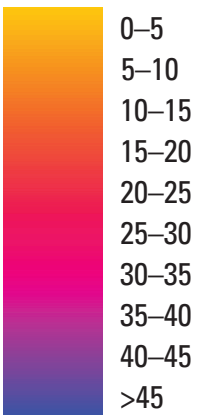

10 MILES
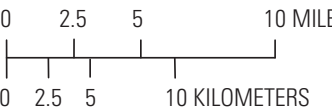

$25 \quad 10$ KILOMETERS

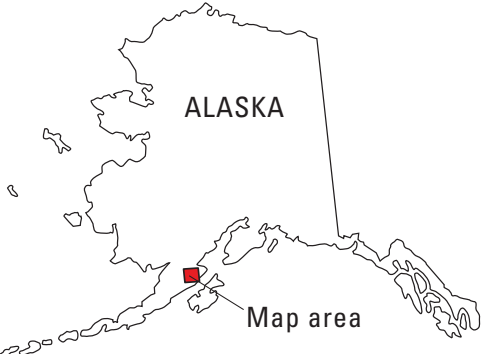

Figure 1.8. Map showing summary plot of earthquakes located by the Alaska Volcano Observatory with the seismic-monitoring subnetwork for the northern part of the Katmai volcanic cluster in 2013-17. 


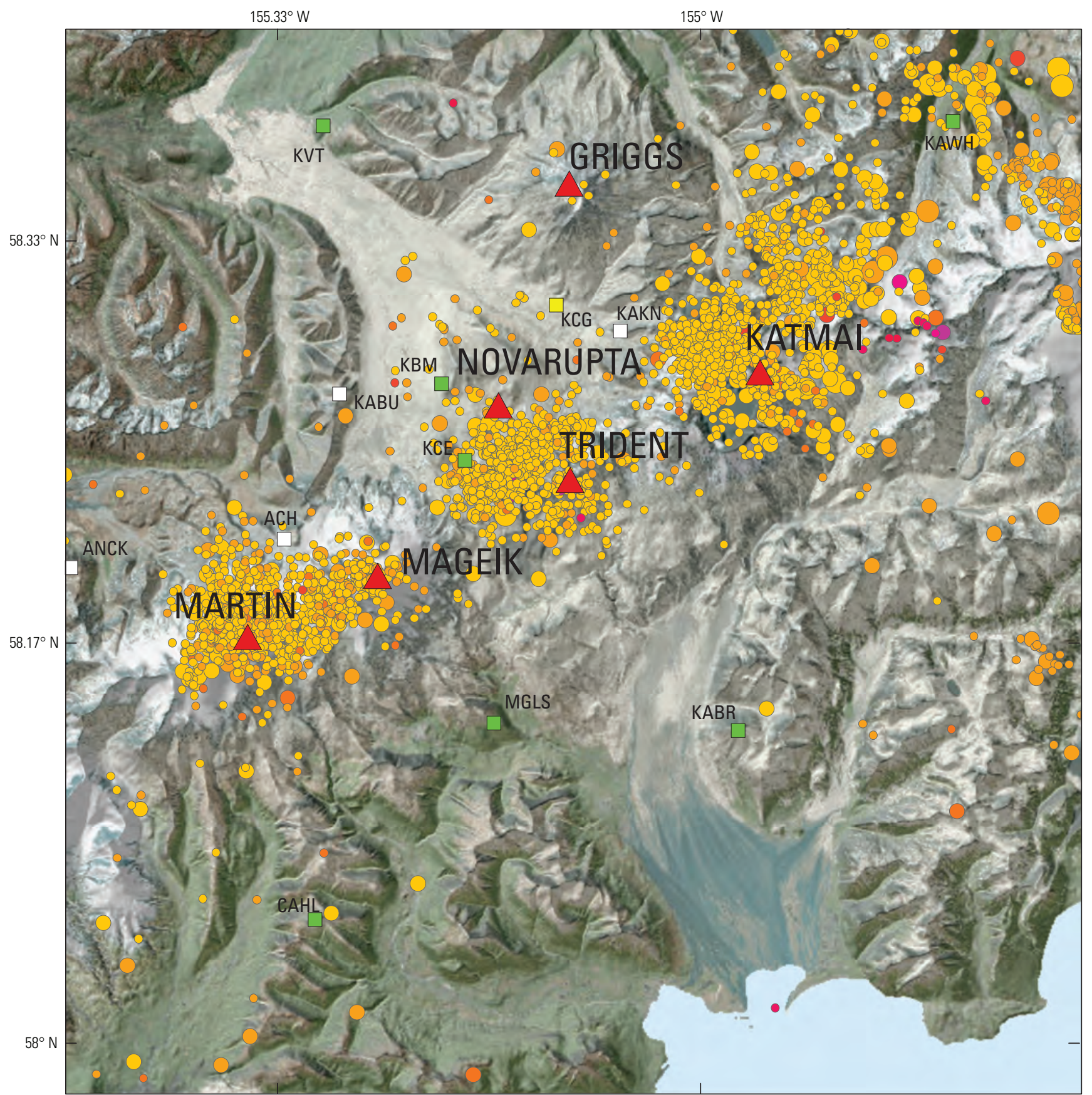

Base from ESRI, DigitalGlobe, GeoEye, Earthstar Geographics, CNES/Airbus DS, USDA, USGS, AeroGRID, IGN, and the GIS User Community, 2018

\section{EXPLANATION}

\section{Southern part of Katmai subnetwork} Seismic stations

$\square \quad$ Single-component short period

$\square \quad$ Three-component broadband

$\square \quad$ Three-component short period

- Pressure sensor

Volcano

Magnitude

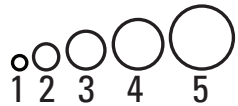

Depth, in kilometers

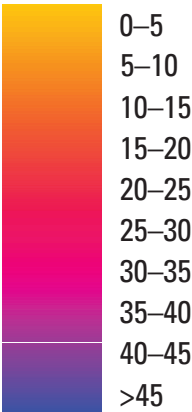

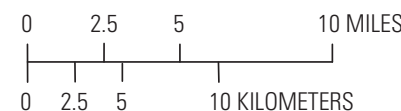

$\begin{array}{llll}0 & 25 & 5 & 10 \text { KILOMETERS }\end{array}$

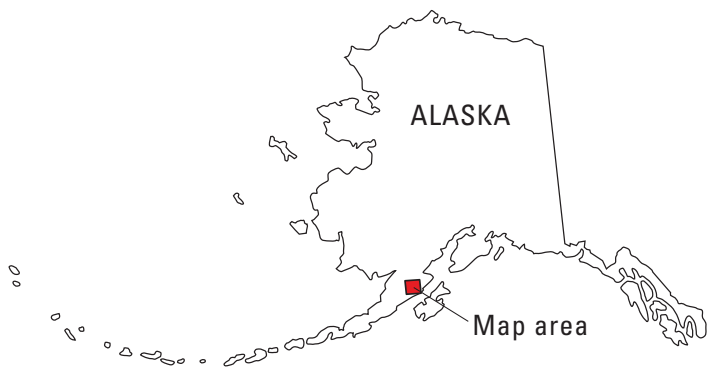

Figure 1.9. Map showing summary plot of earthquakes located by the Alaska Volcano Observatory with the seismic-monitoring subnetwork for the southern part of the Katmai volcanic cluster in 2013-17. 

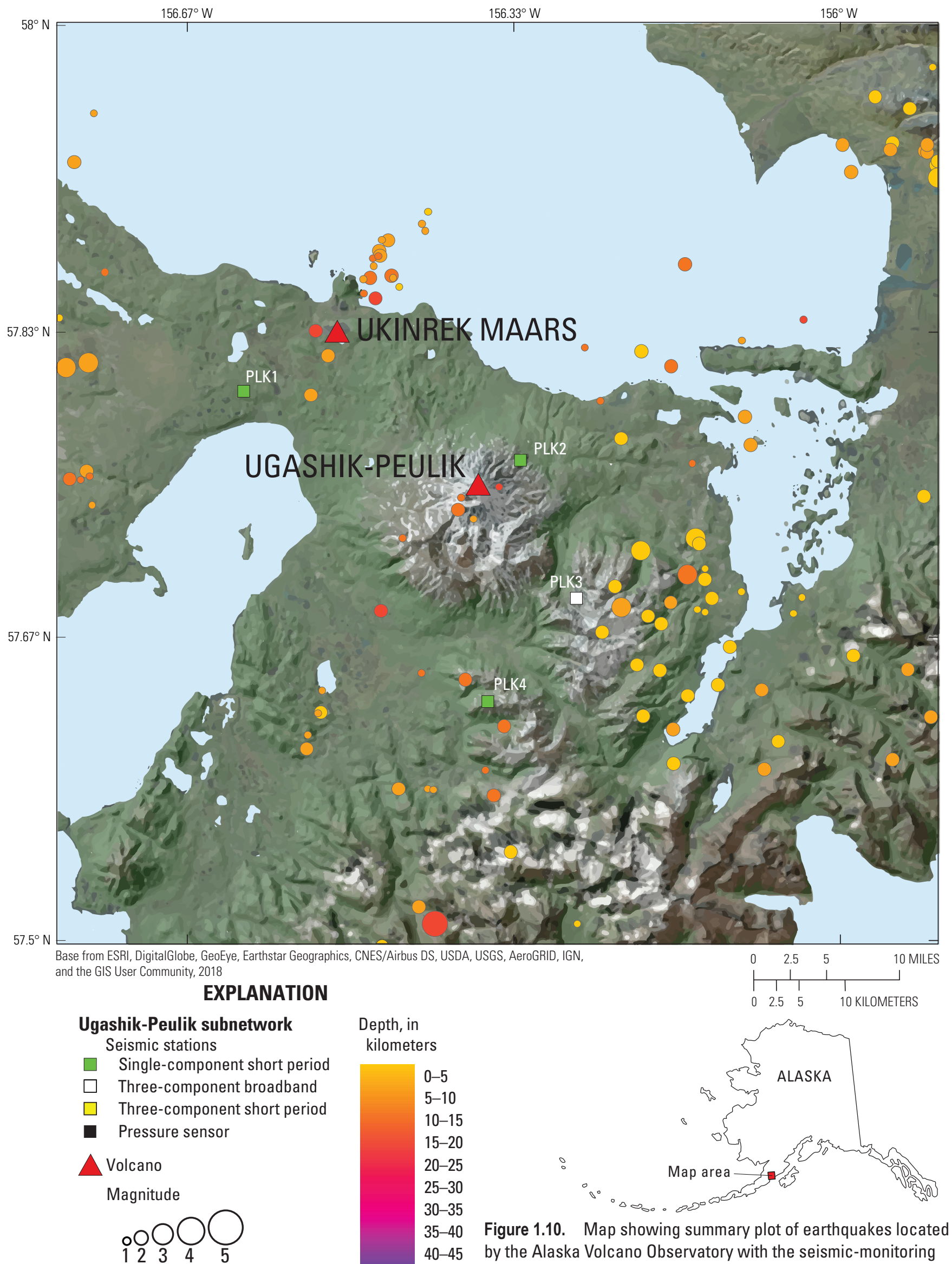

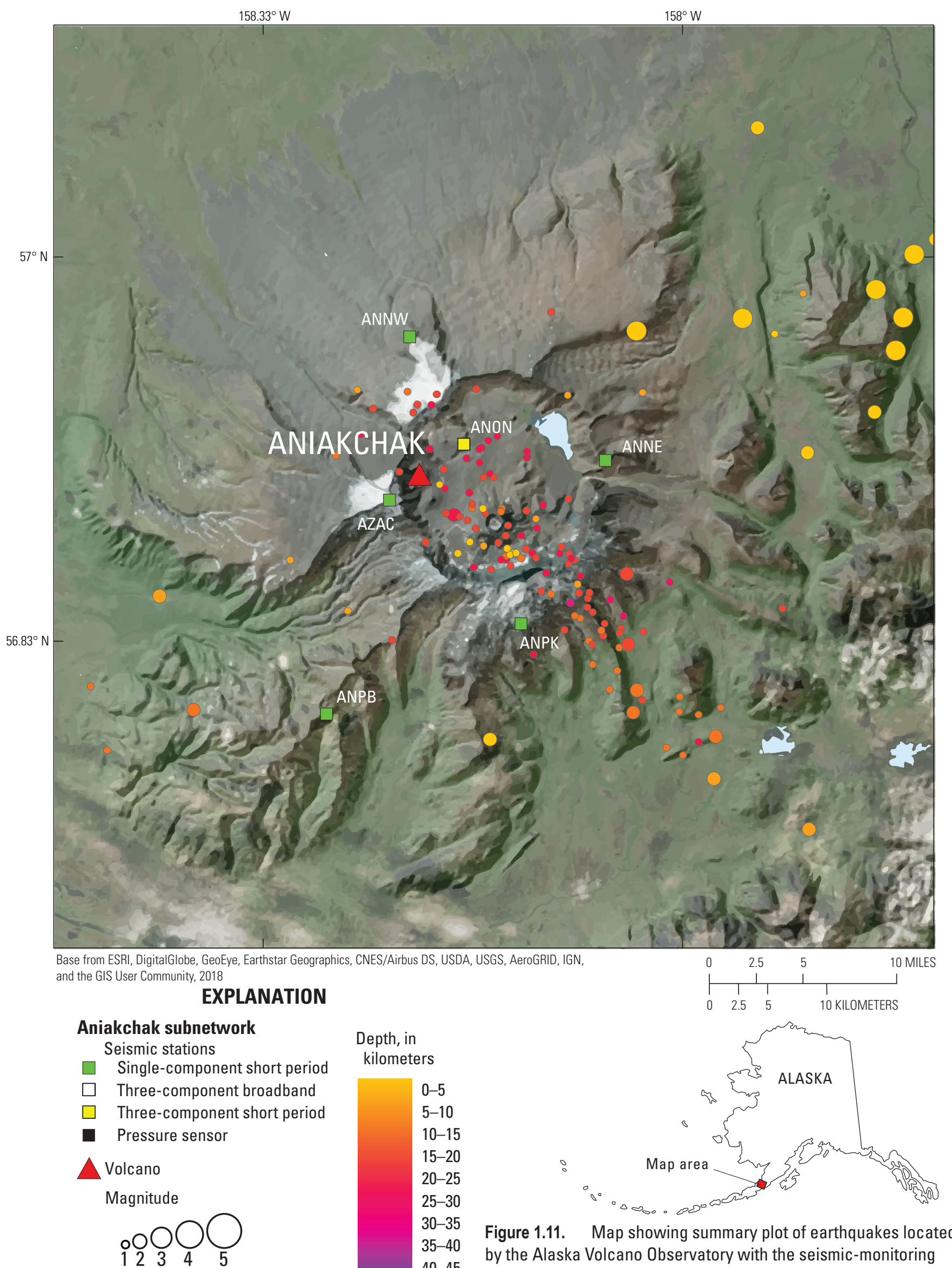

30-35

35-40

40-45

Figure 1.11. Map showing summary plot of earthquakes located by the Alaska Volcano Observatory with the seismic-monitoring subnetwork at Aniakchak Crater in 2013-17. 


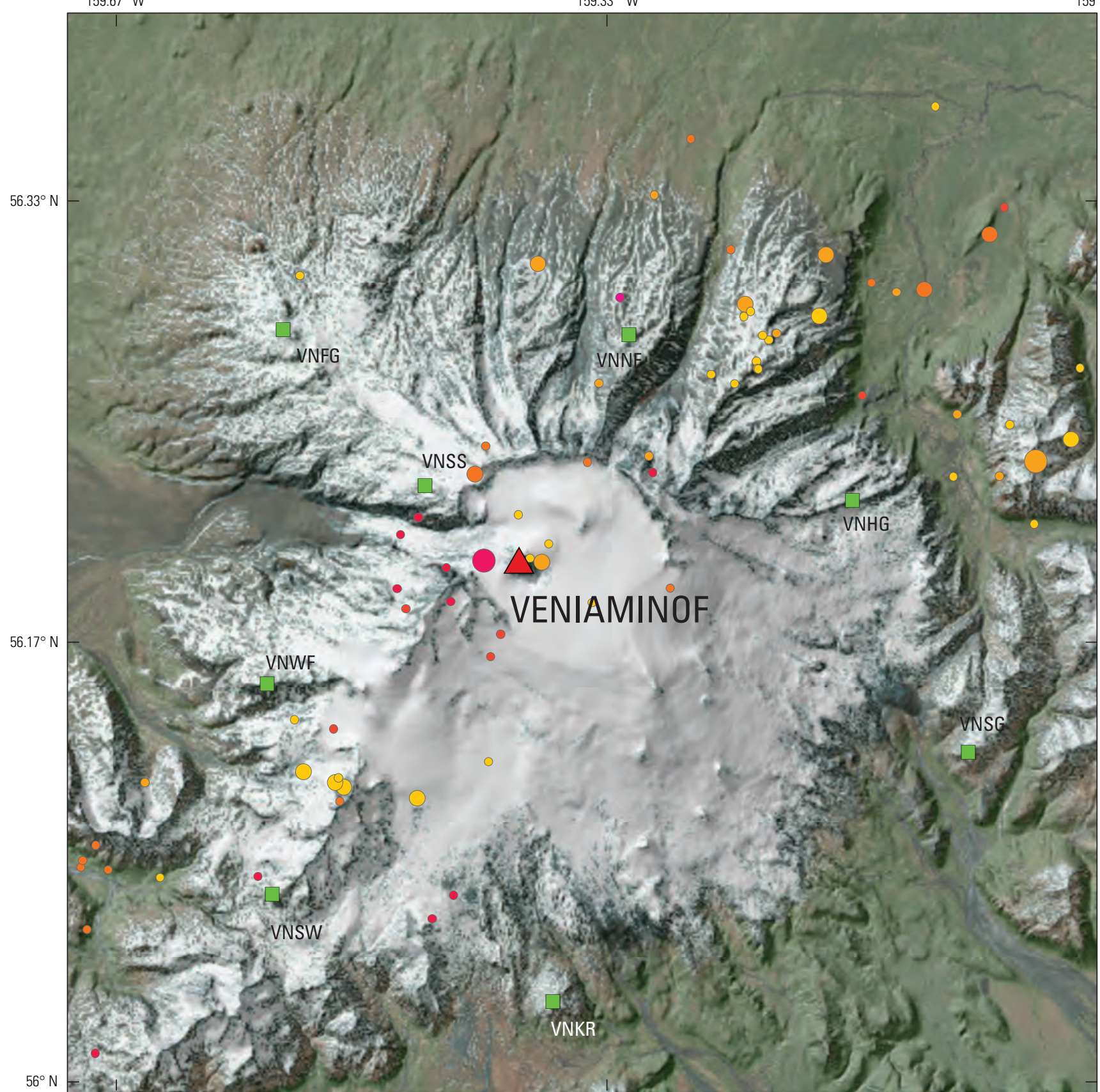

Base from ESRI, DigitalGlobe, GeoEye, Earthstar Geographics, CNES/Airbus DS, USDA, USGS, AeroGRID, IGN and the GIS User Community, 2018

\section{EXPLANATION}

\section{Veniaminof subnetwork}

Seismic stations

Single-component short period

$\square \quad$ Three-component broadband

$\square \quad$ Three-component short period

- Pressure sensor

Volcano

Magnitude

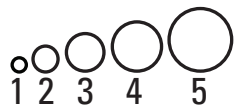

Depth, in

kilometers

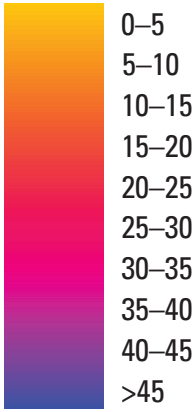

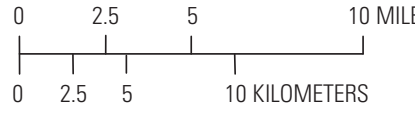

10 MILES

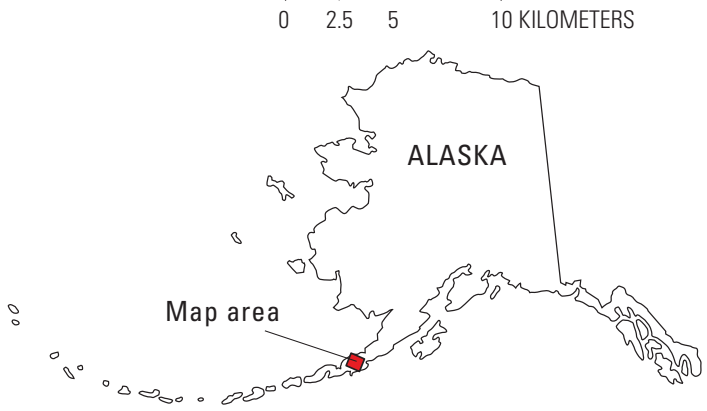

Figure 1.12. Map showing summary plot of earthquakes located by the Alaska Volcano Observatory with the seismic-monitoring subnetwork at Mount Veniaminof in 2013-17. 


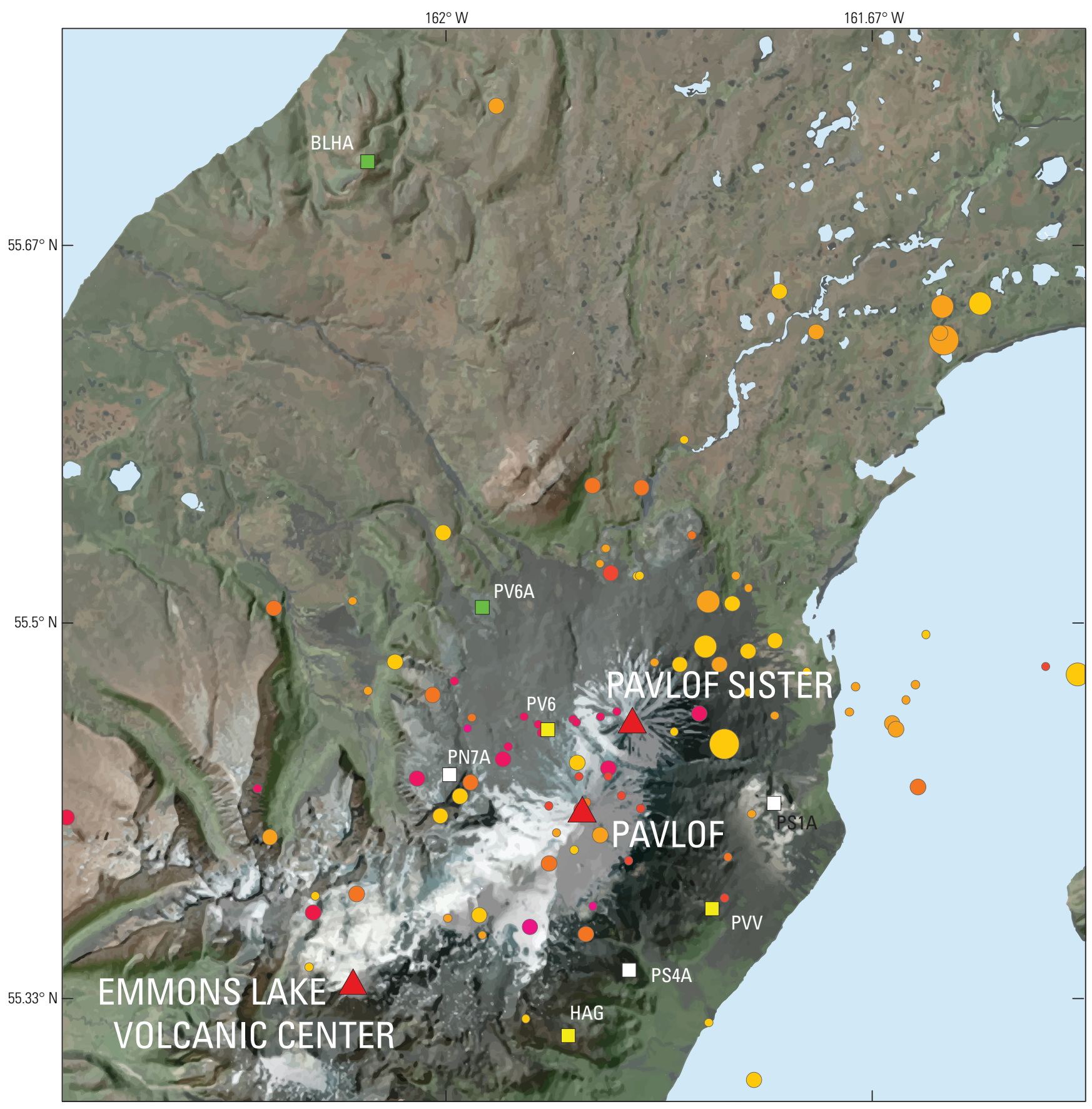

Base from ESRI, DigitalGlobe, GeoEye, Earthstar Geographics, CNES/Airbus DS, USDA, USGS, AeroGRID, IGN and the GIS User Community, 2018

\section{EXPLANATION}

\section{Pavlof subnetwork}

Seismic stations

$\square \quad$ Single-component short period

$\square \quad$ Three-component broadband

$\square \quad$ Three-component short period

- Pressure sensor

$\triangle$ Volcano

Magnitude

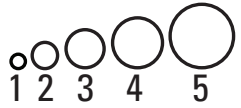

Depth, in

kilometers

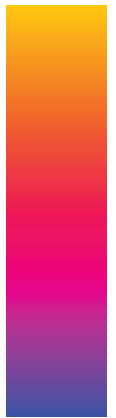

$0-5$

$5-10$

$10-15$

$15-20$

20-25

$25-30$

$30-35$

$35-40$

$40-45$

$>45$
10 MILES
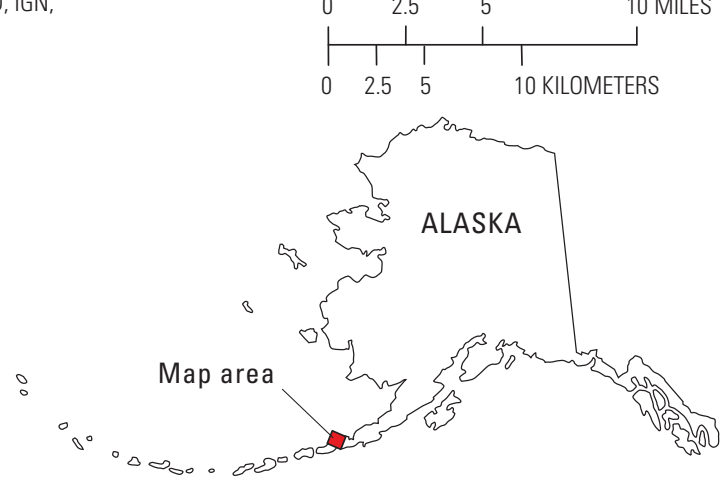

Figure 1.13. Map showing summary plot of earthquakes located by the Alaska Volcano Observatory with the seismic-monitoring subnetwork at Pavlof Volcano in 2013-17. 

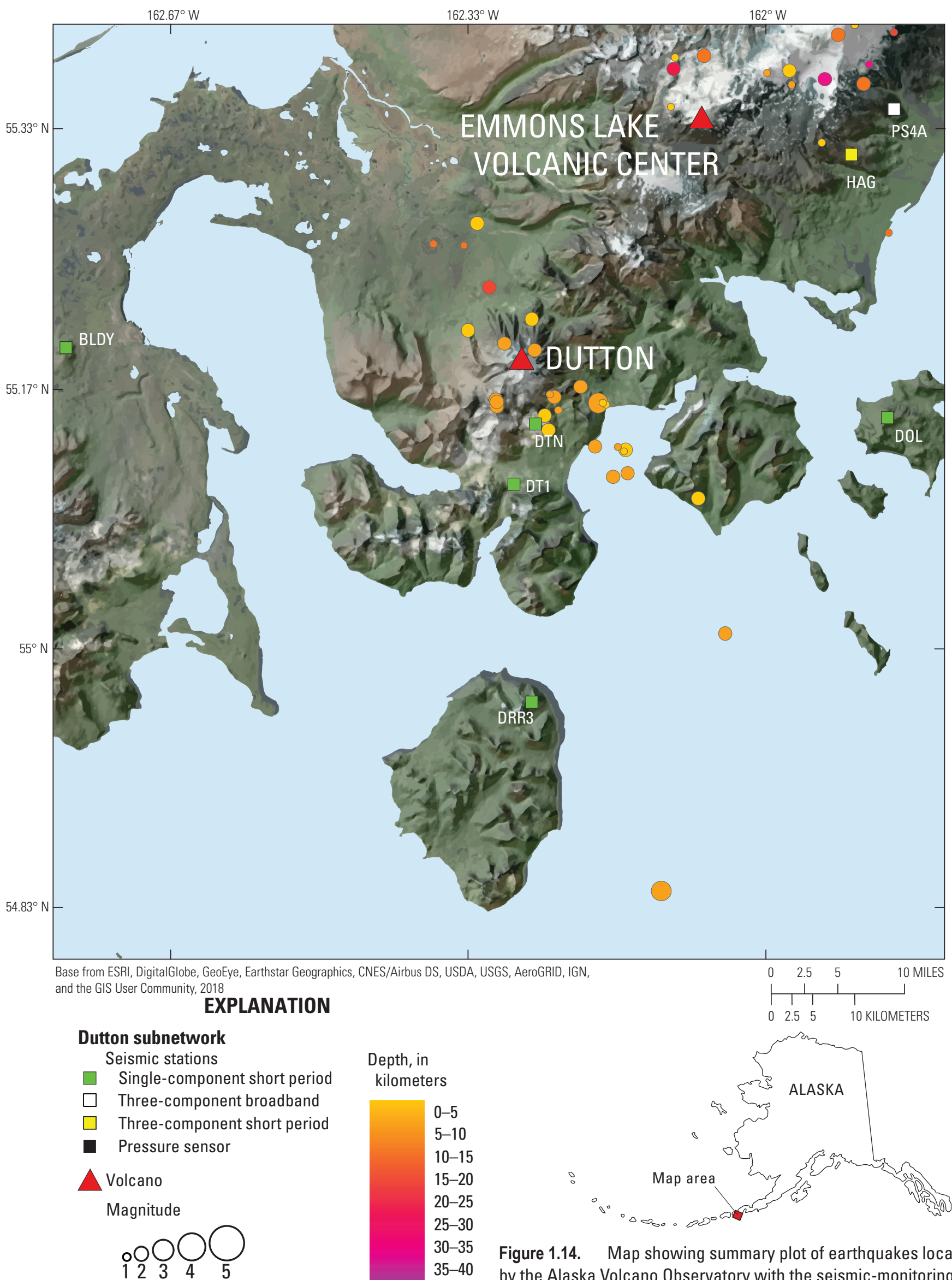

$30-35$ by the Alaska Volcano Observatory with the seismic-monitoring 40-45 subnetwork at Mount Dutton in 2013-17. 


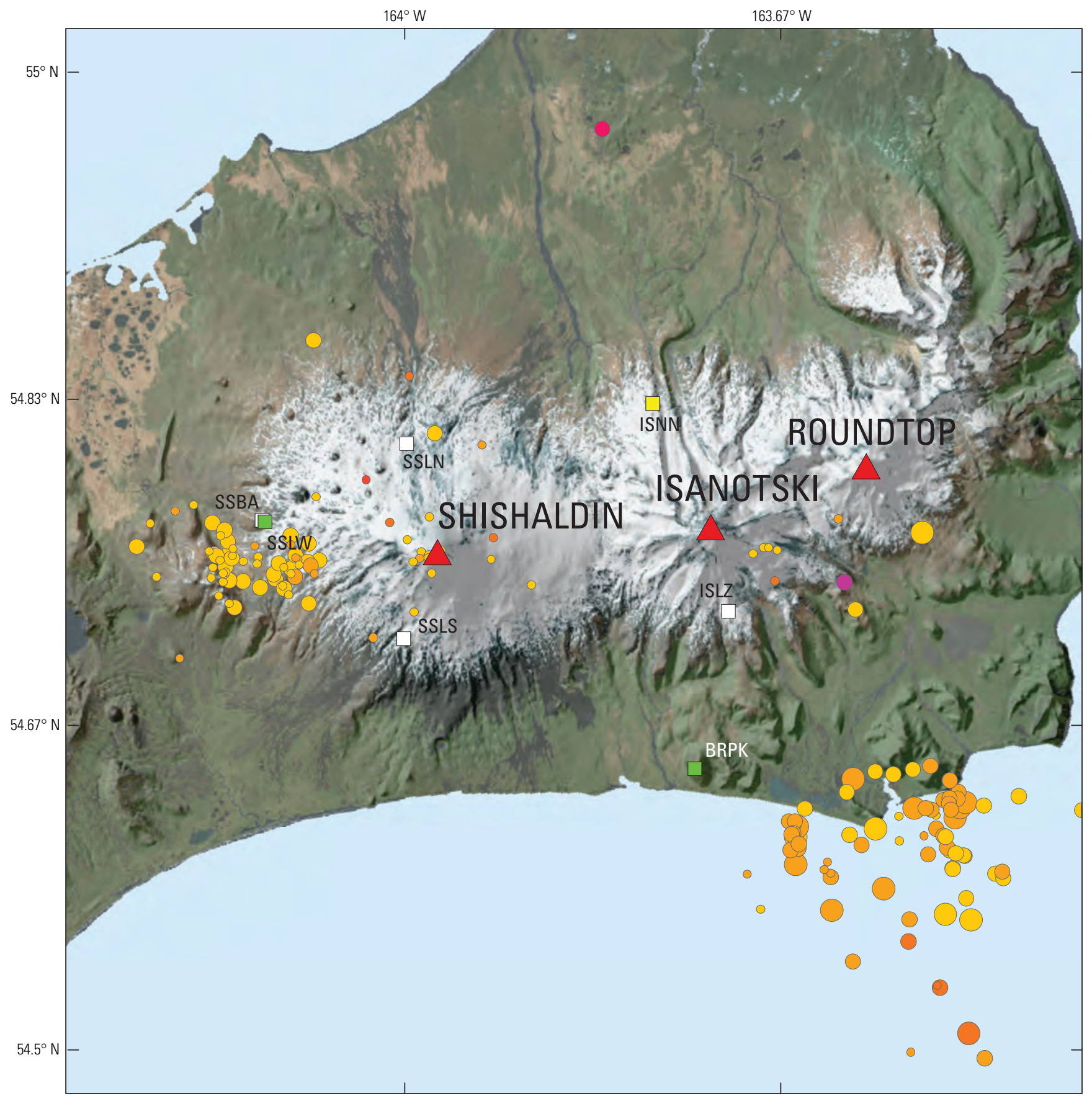

Base from ESRI, DigitalGlobe, GeoEye, Earthstar Geographics, CNES/Airbus DS, USDA, USGS, AeroGRID, IGN, and the GIS User Community, 2018

\section{EXPLANATION}

\section{Shishaldin subnetwork}

Seismic stations

Single-component short period

$\square \quad$ Three-component broadband

$\square \quad$ Three-component short period

- Pressure sensor

$\triangle$ Volcano

Magnitude

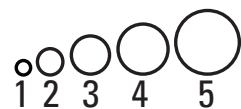

Depth, in

kilometers

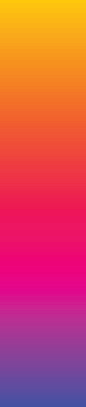

$0-5$

$5-10$

$10-15$

$15-20$

$20-25$

$25-30$

$30-35$

$35-40$

$40-45$ $>45$
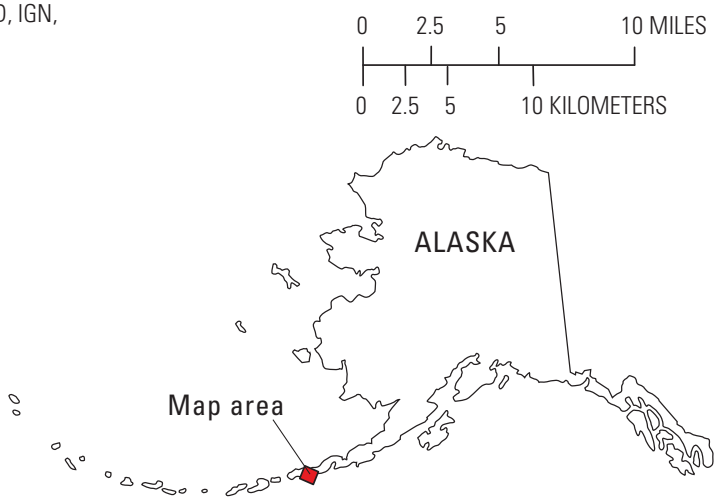

Figure 1.15. Map showing summary plot of earthquakes located by the Alaska Volcano Observatory with the seismic-monitoring subnetwork at Shishaldin Volcano in 2013-17. 

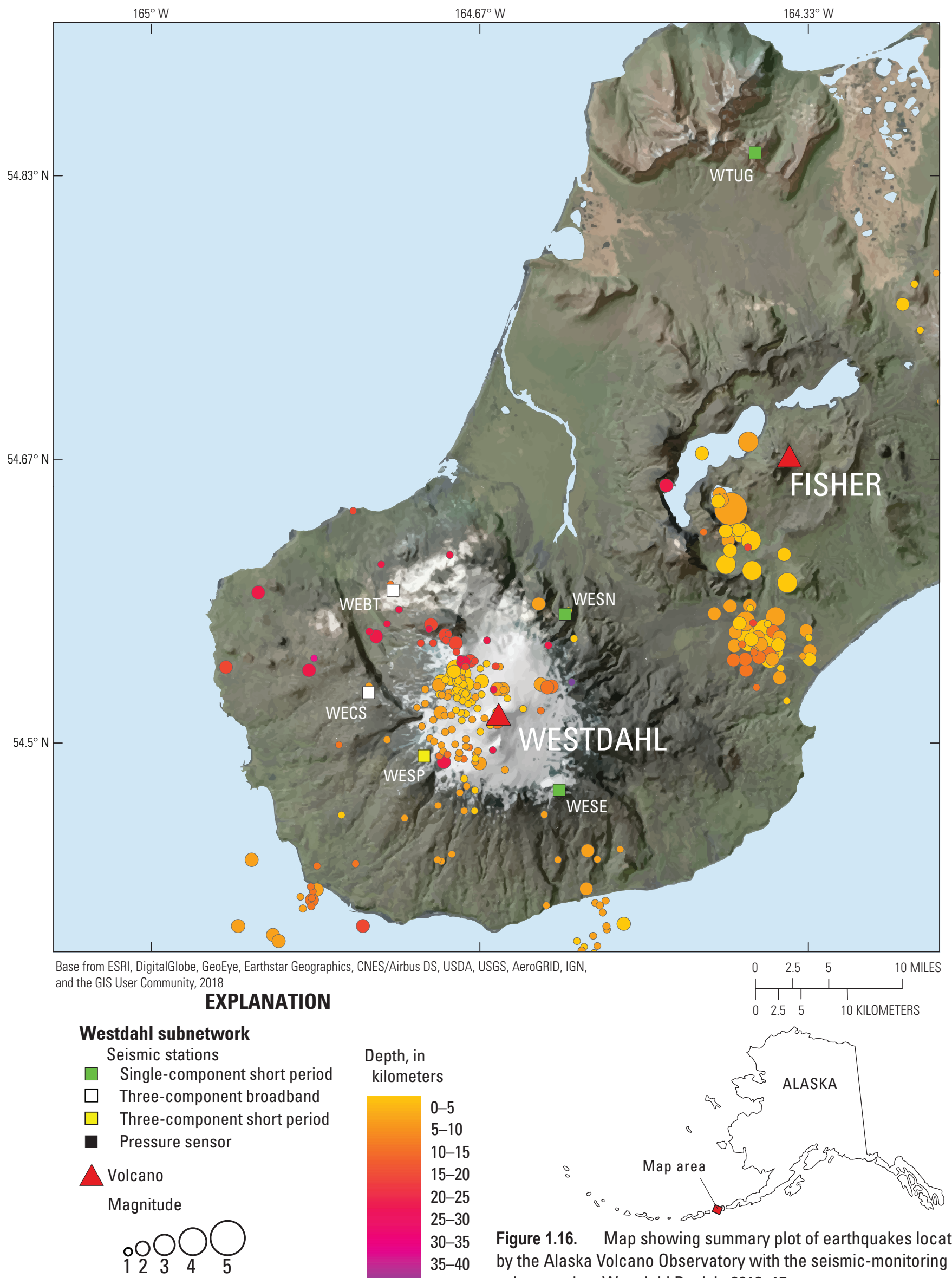

30-35 Figure 1.16. Map showing summary plot of earthquakes located 35-40 by the Alaska Volcano Observatory with the seismic-monitoring 40-45 subnetwork at Westdahl Peak in 2013-17. 


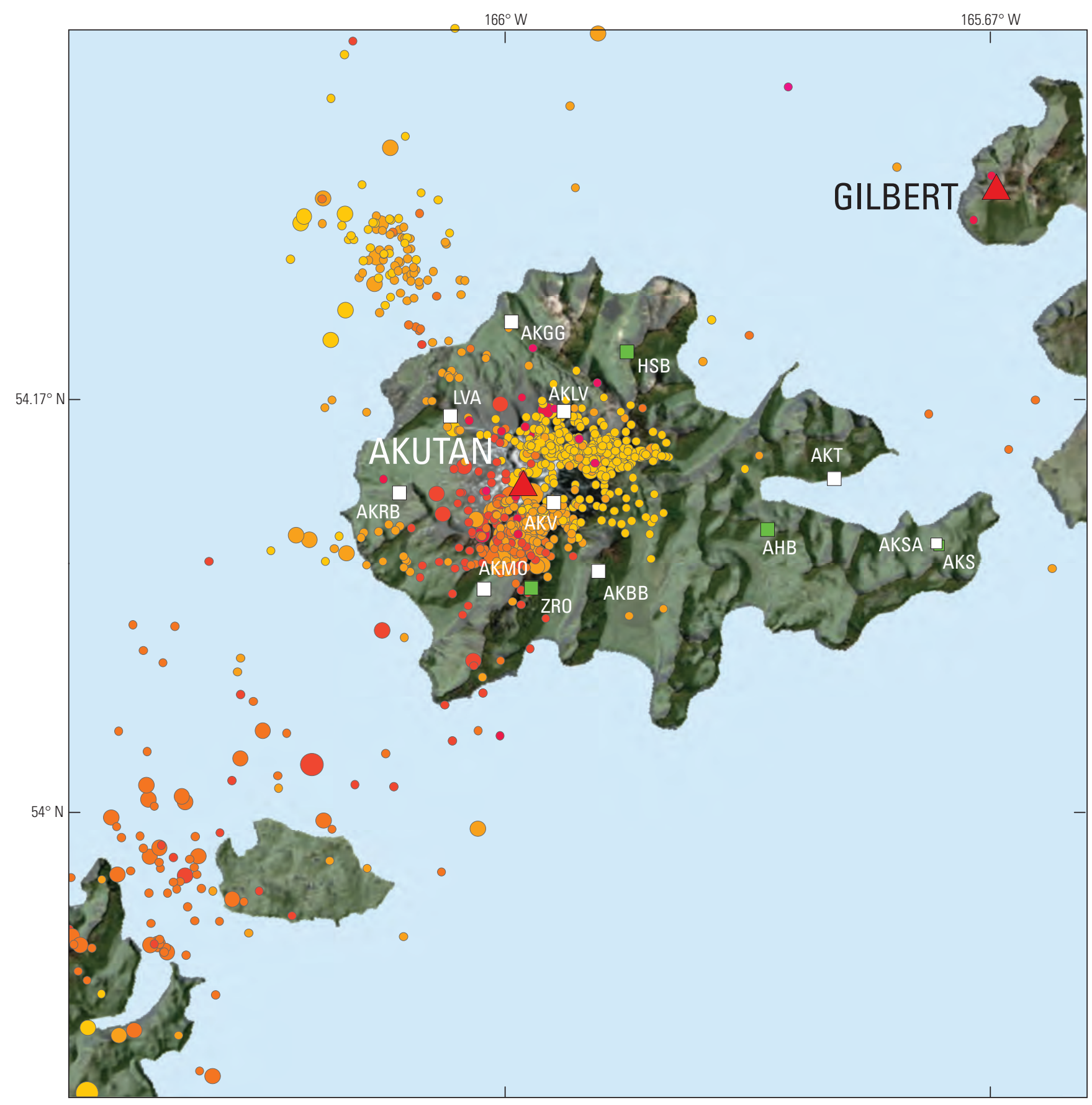

Base from ESRI, DigitalGlobe, GeoEye, Earthstar Geographics, CNES/Airbus DS, USDA, USGS, AeroGRID, IGN, and the GIS User Community, 2018

\section{EXPLANATION}

\section{Akutan subnetwork}

Seismic stations

$\square \quad$ Single-component short period

$\square \quad$ Three-component broadband

$\square \quad$ Three-component short period

- Pressure sensor

$\triangle$ Volcano

Magnitude

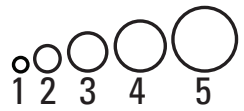

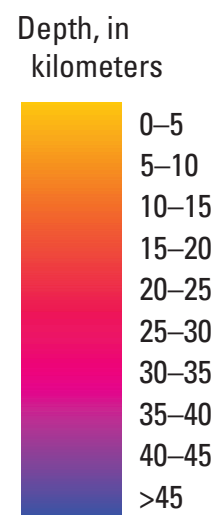
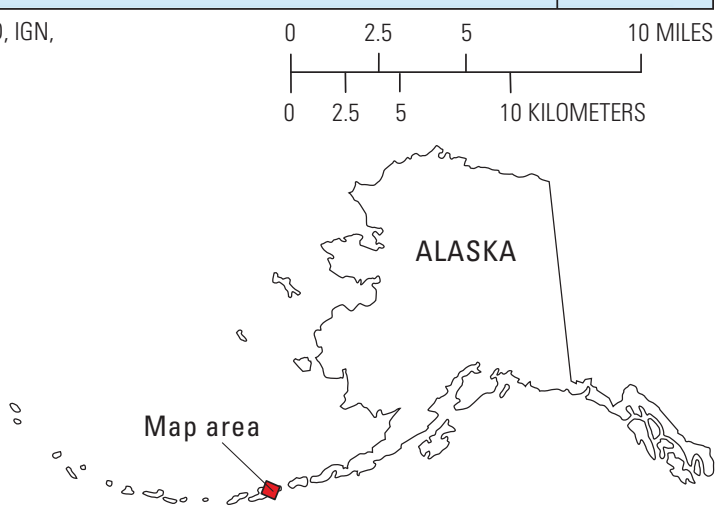

Figure 1.17. Map showing summary plot of earthquakes located by the Alaska Volcano Observatory with the seismic-monitoring subnetwork at Akutan Peak in 2013-17. 


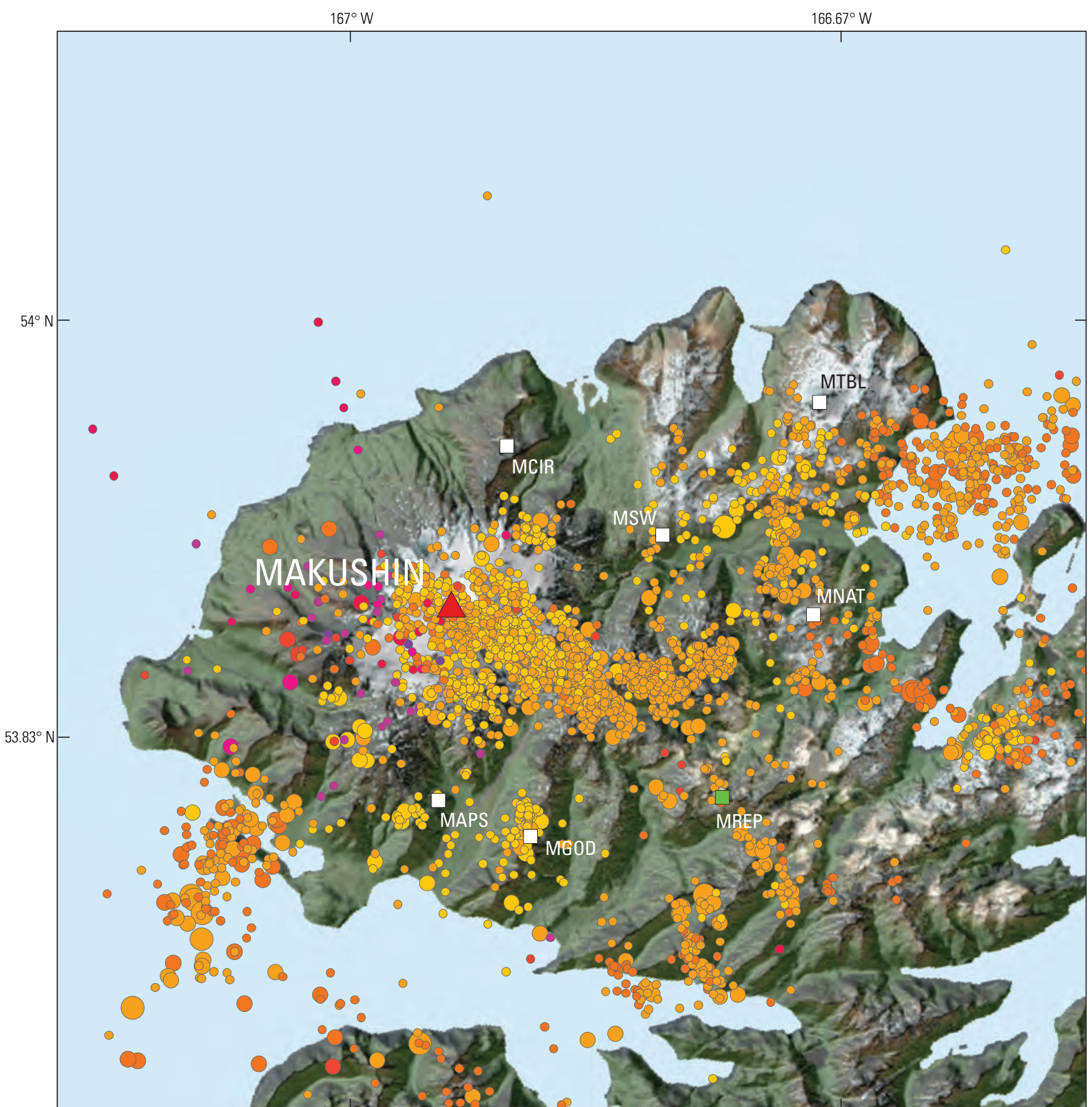

Base from ESRI, DigitalGlobe, GeoEye, Earthstar Geographics, CNES/Airbus DS, USDA, USGS, AeroGRID, IGN, and the GIS User Community, 2018

\section{EXPLANATION}

\section{Makushin subnetwork}

Seismic stations

$\square \quad$ Single-component short period

$\square \quad$ Three-component broadband

$\square \quad$ Three-component short period

- Pressure sensor

$\triangle$ Volcano

Magnitude

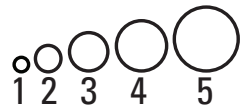

Depth, in

kilometers

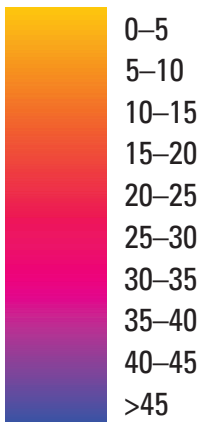

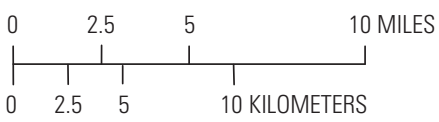

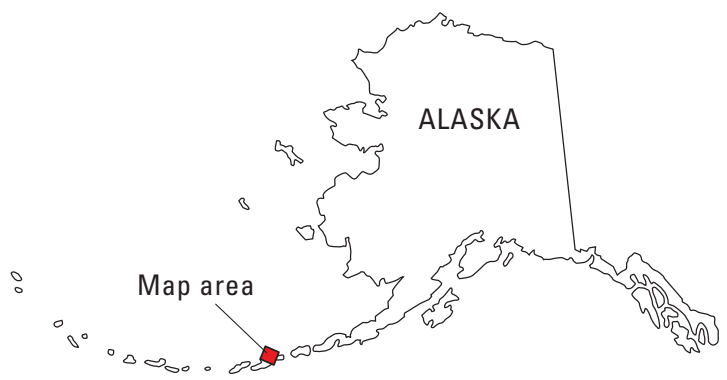

Figure 1.18. Map showing summary plot of earthquakes located by the Alaska Volcano Observatory with the seismic-monitoring subnetwork at Makushin Volcano in 2013-17. 

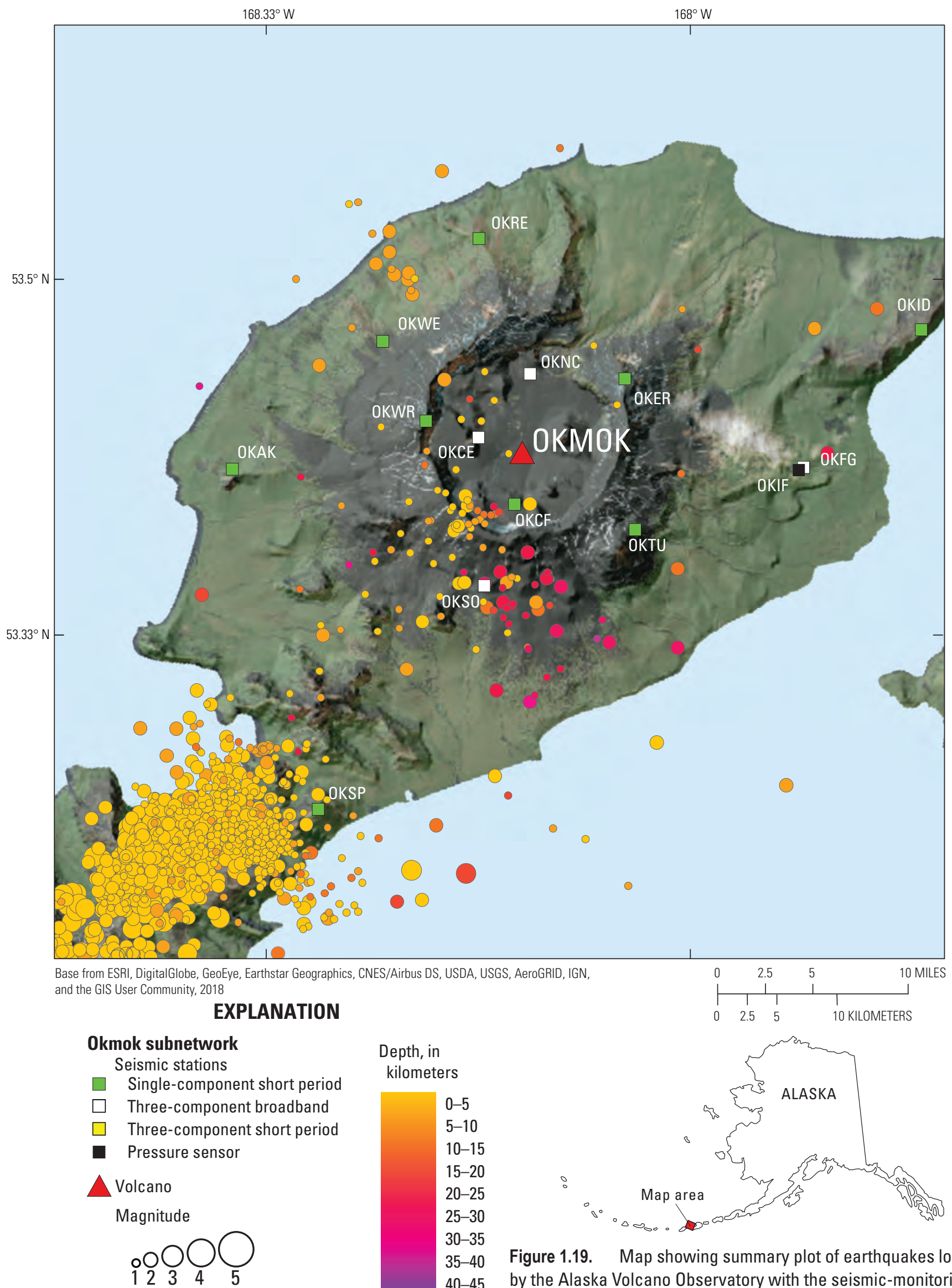

$30-35$

$35-40$

$40-45$

Figure 1.19. Map showing summary plot of earthquakes located by the Alaska Volcano Observatory with the seismic-monitoring $>45$ subnetwork at Okmok Caldera in 2013-17. 

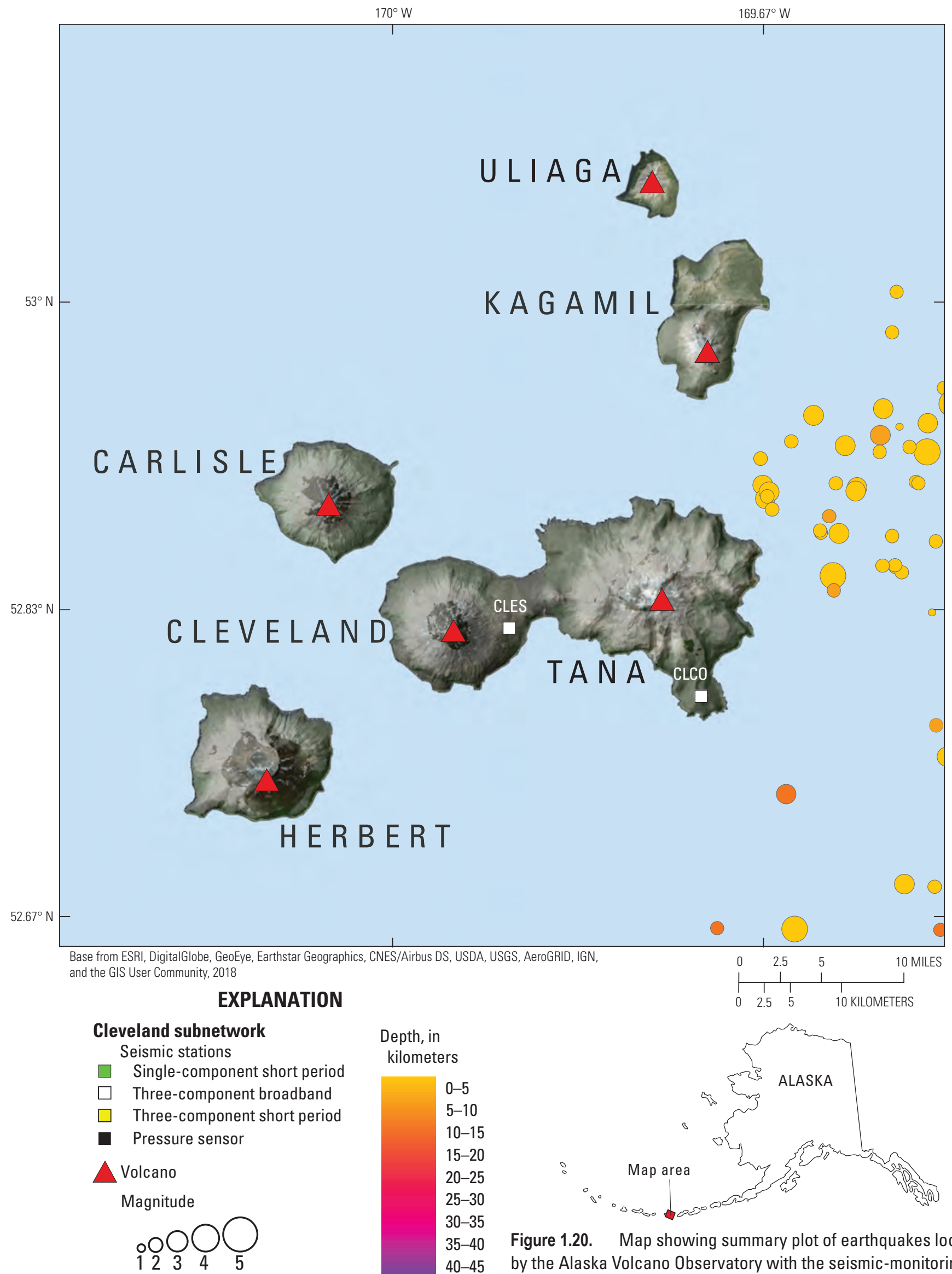

35-40 Figure 1.20. Map showing summary plot of earthquakes located 40-45 by the Alaska Volcano Observatory with the seismic-monitoring $>45$ subnetwork at Mount Cleveland in 2013-17. 

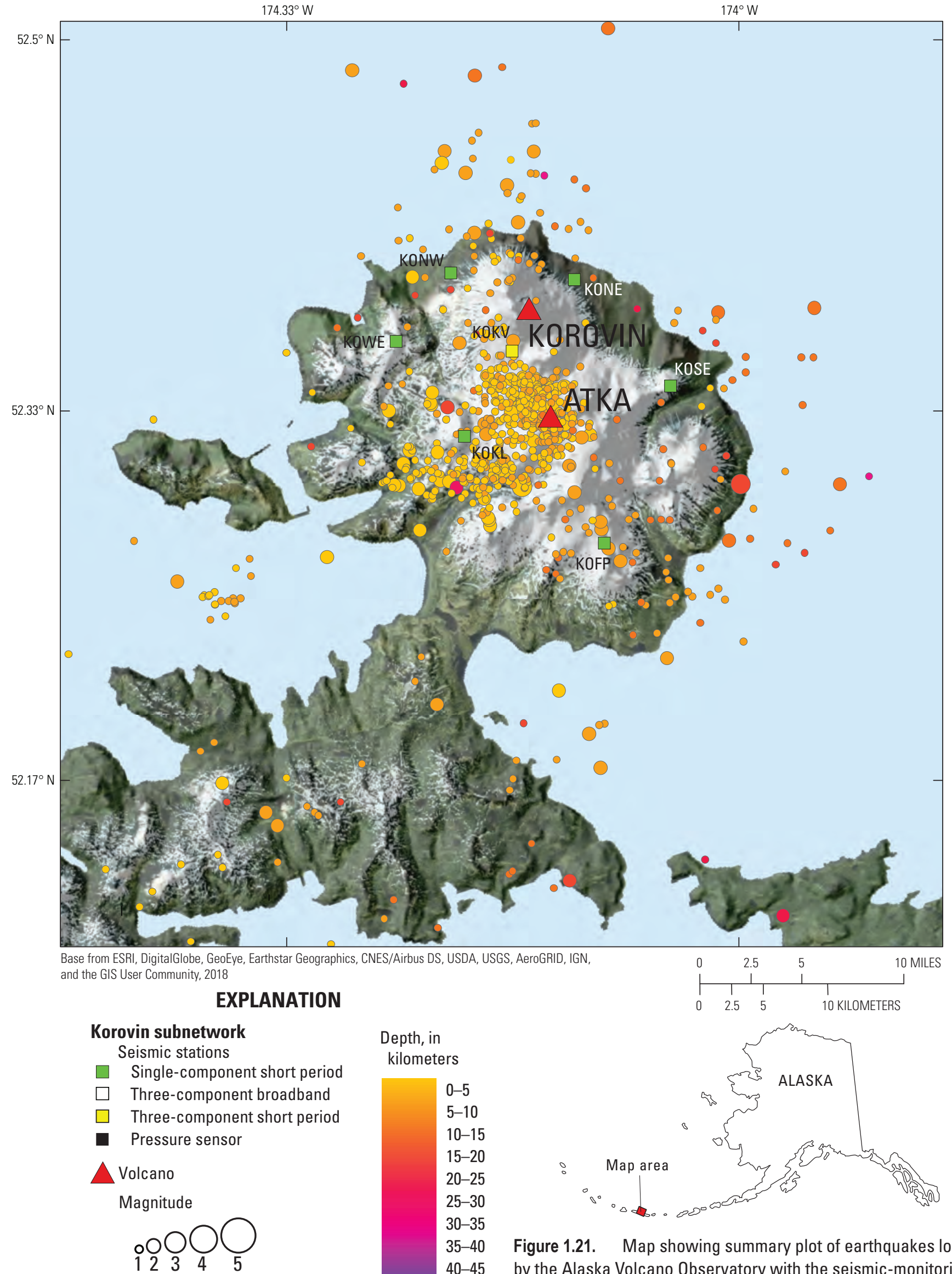

35-40 Figure 1.21. Map showing summary plot of earthquakes located 40-45 by the Alaska Volcano Observatory with the seismic-monitoring $>45$ subnetwork at Korovin Volcano in 2013-17. 


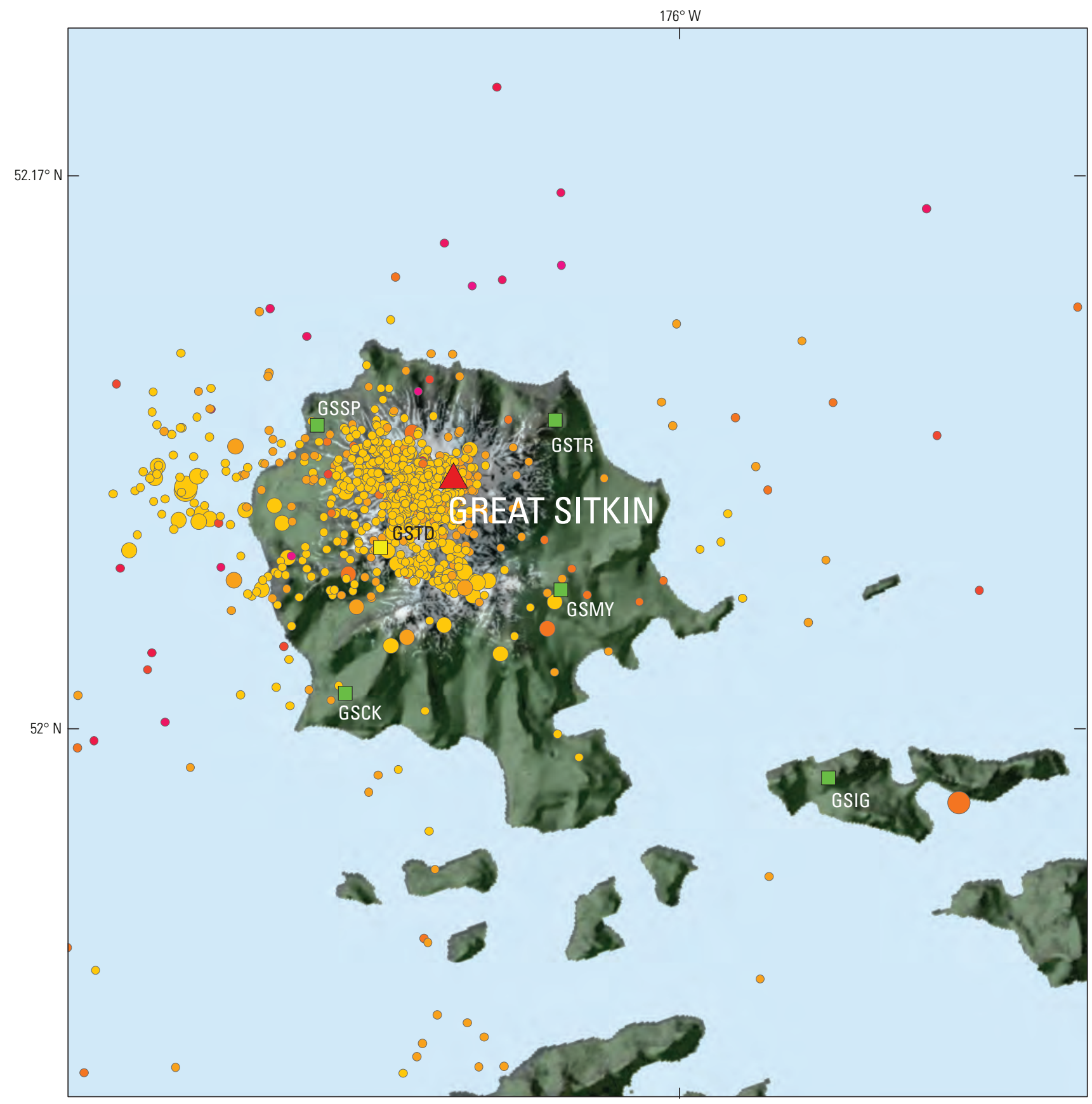

Base from ESRI, DigitalGlobe, GeoEye, Earthstar Geographics, CNES/Airbus DS, USDA, USGS, AeroGRID, IGN, and the GIS User Community, 2018

\section{EXPLANATION}

\section{Great Sitkin subnetwork} Seismic stations

Single-component short period

Three-component broadband

$\square \quad$ Three-component short period

- Pressure sensor

Volcano

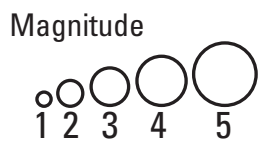

Depth, in kilometers

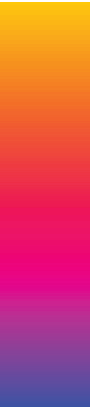
$5-10$ $10-15$ $15-20$ $20-25$ 25-30 30-35 35-40 $40-45$ $>45$
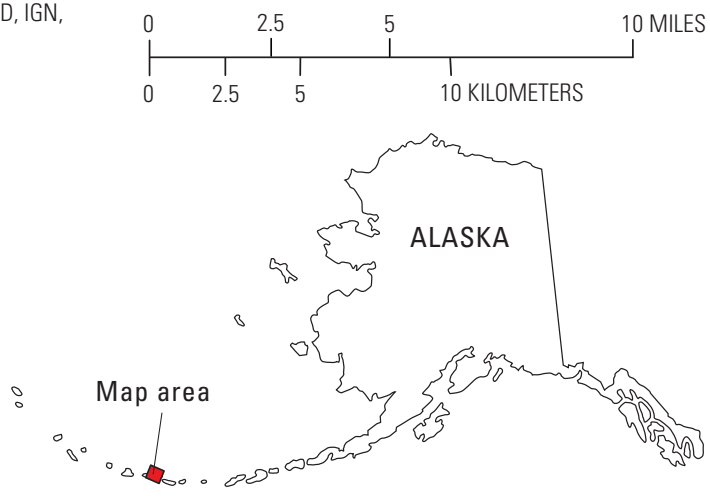

Figure 1.22. Map showing summary plot of earthquakes located by the Alaska Volcano Observatory with the seismic-monitoring subnetwork at Great Sitkin Volcano in 2013-17. 

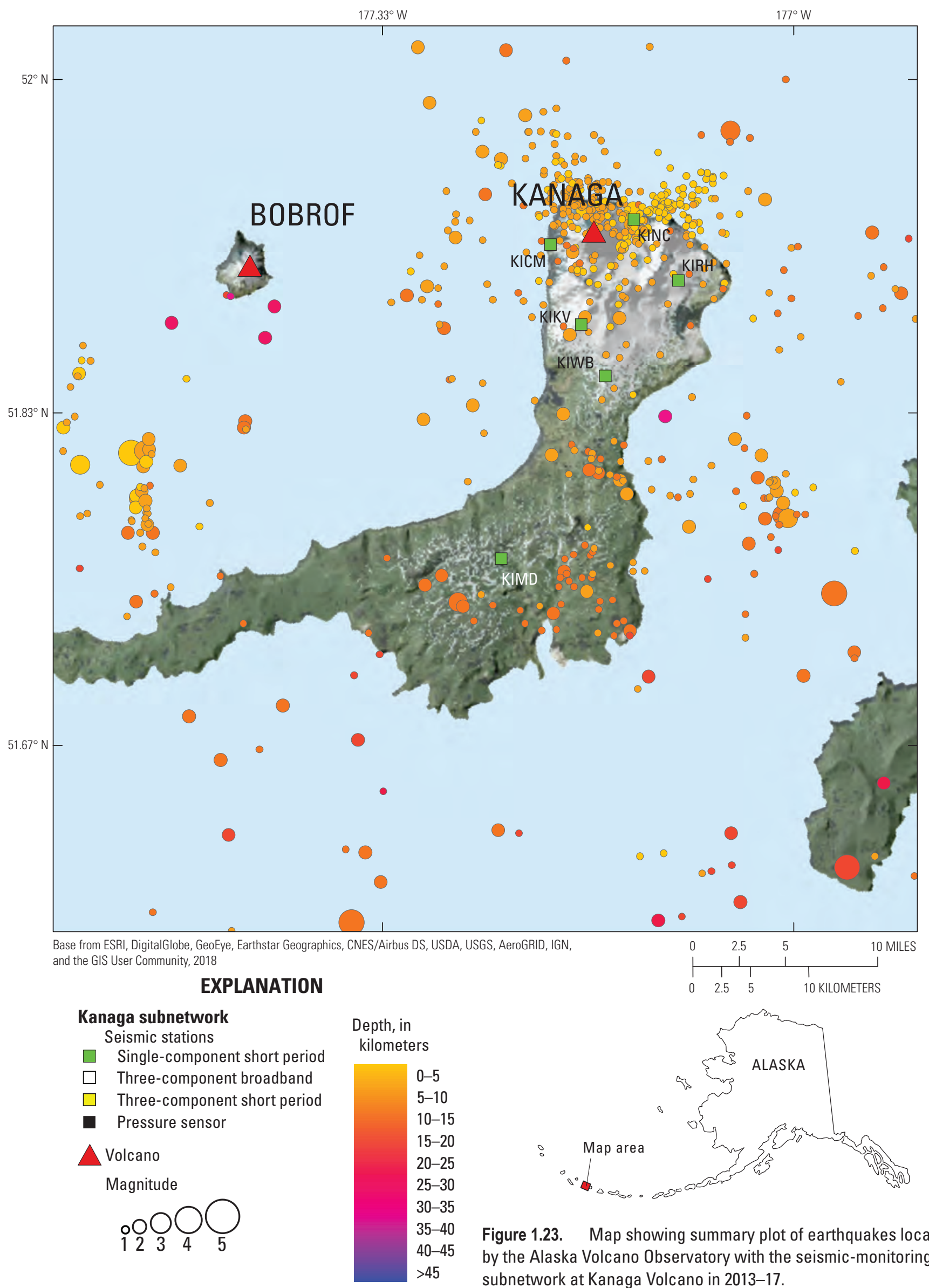

Figure 1.23. Map showing summary plot of earthquakes located by the Alaska Volcano Observatory with the seismic-monitoring subnetwork at Kanaga Volcano in 2013-17. 


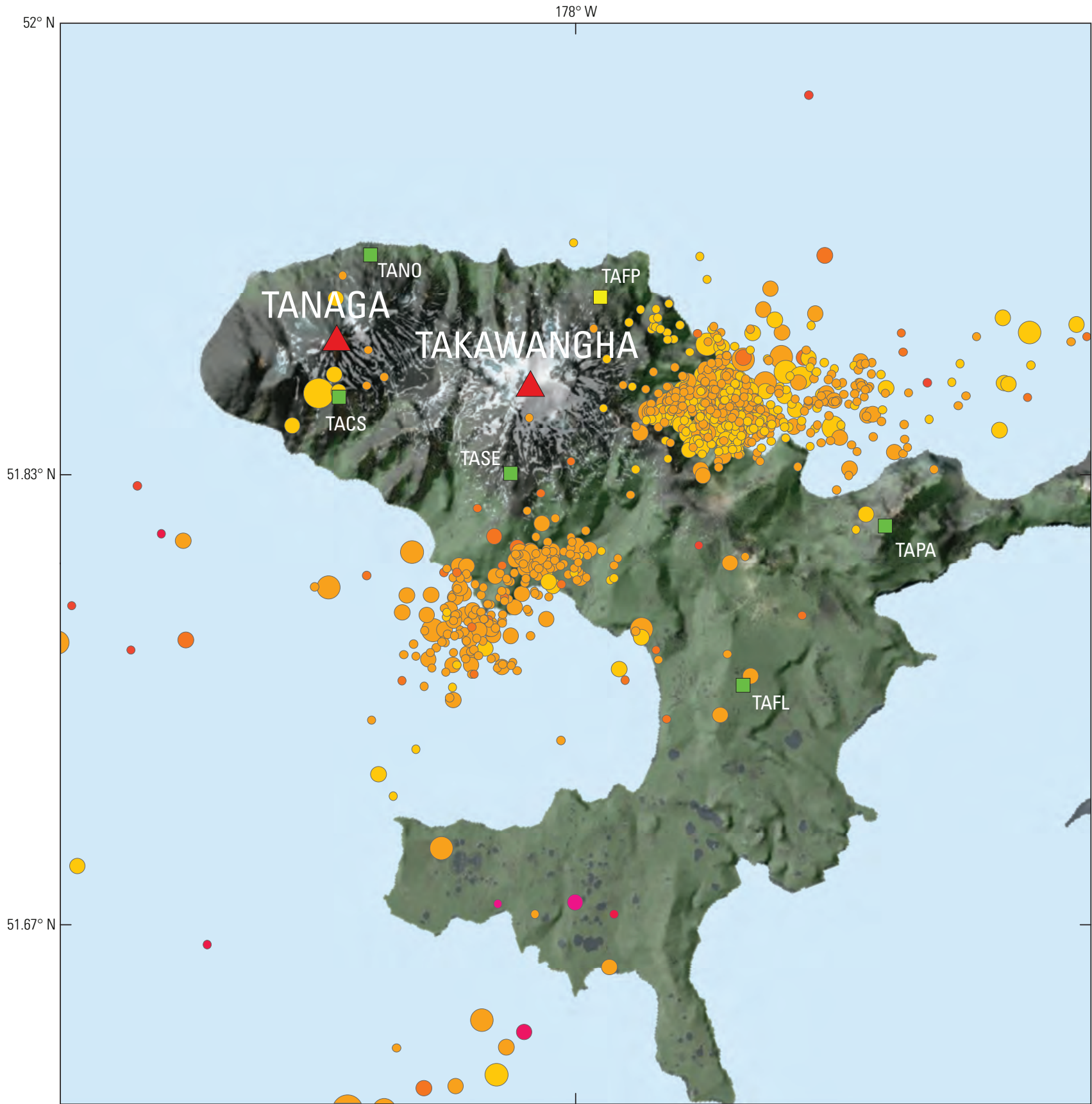

Base from ESRI, DigitalGlobe, GeoEye, Earthstar Geographics, CNES/Airbus DS, USDA, USGS, AeroGRID, IGN, and the GIS User Community, 2018

\section{EXPLANATION}

Tanaga subnetwork

Seismic stations

$\square$ Single-component short period

$\square \quad$ Three-component broadband

$\square \quad$ Three-component short period

- Pressure sensor

$\triangle$ Volcano

Magnitude

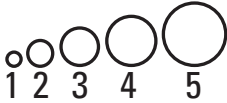

Depth, in

kilometers

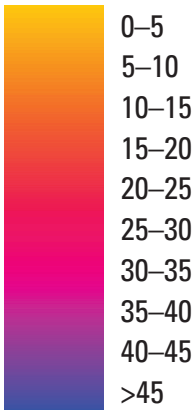

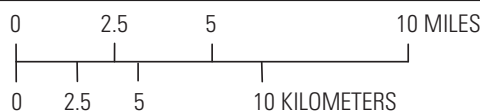

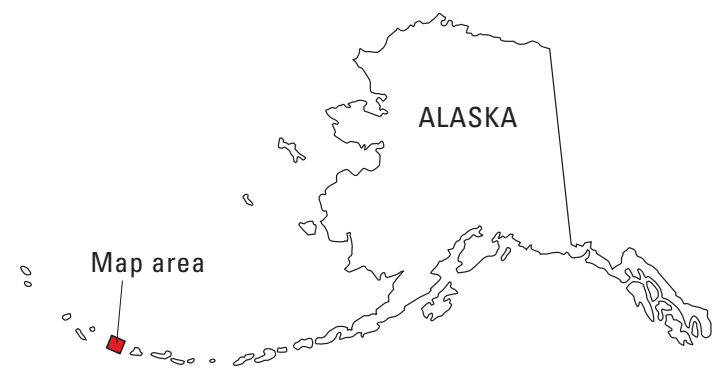

Figure 1.24. Map showing summary plot of earthquakes located by the Alaska Volcano Observatory with the seismic-monitoring subnetwork at Tanaga Volcano in 2013-17. 


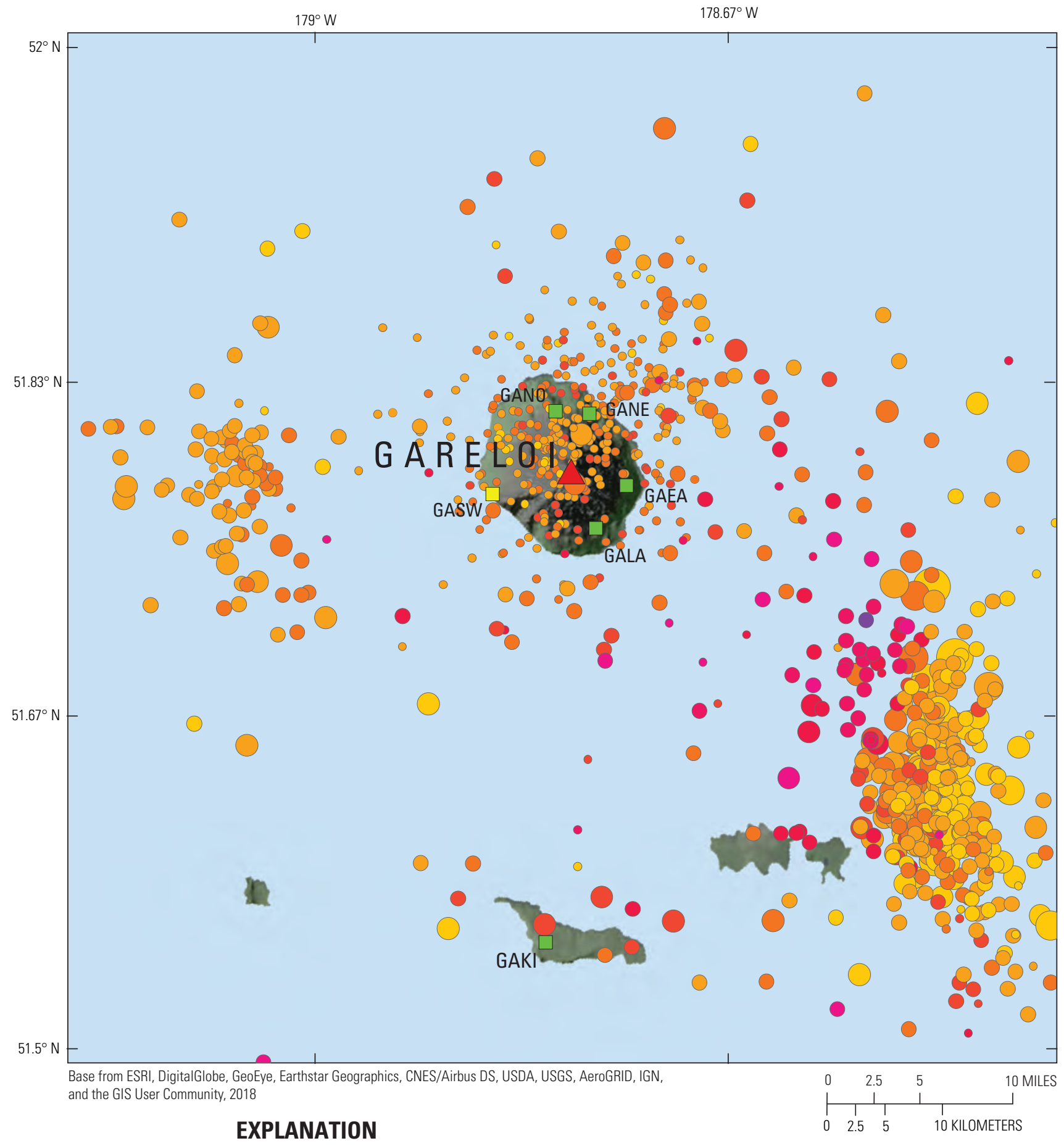

\section{Gareloi subnetwork}

Seismic stations

$\square \quad$ Single-component short period

$\square \quad$ Three-component broadband

$\square \quad$ Three-component short period

- Pressure sensor

Volcano

Magnitude

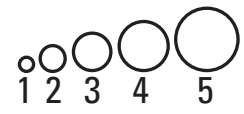

Depth, in

kilometers

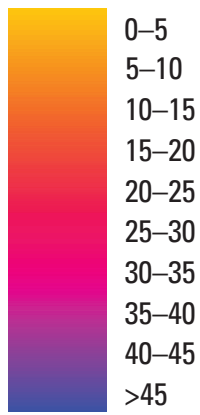

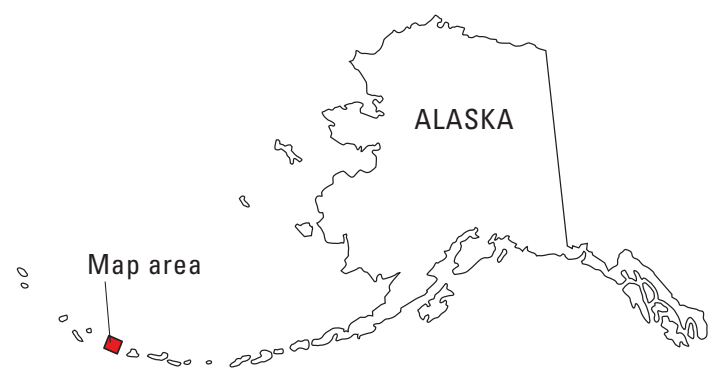

Figure 1.25. Map showing summary plot of earthquakes located by the Alaska Volcano Observatory with the seismic-monitoring subnetwork at Mount Gareloi in 2013-17. 


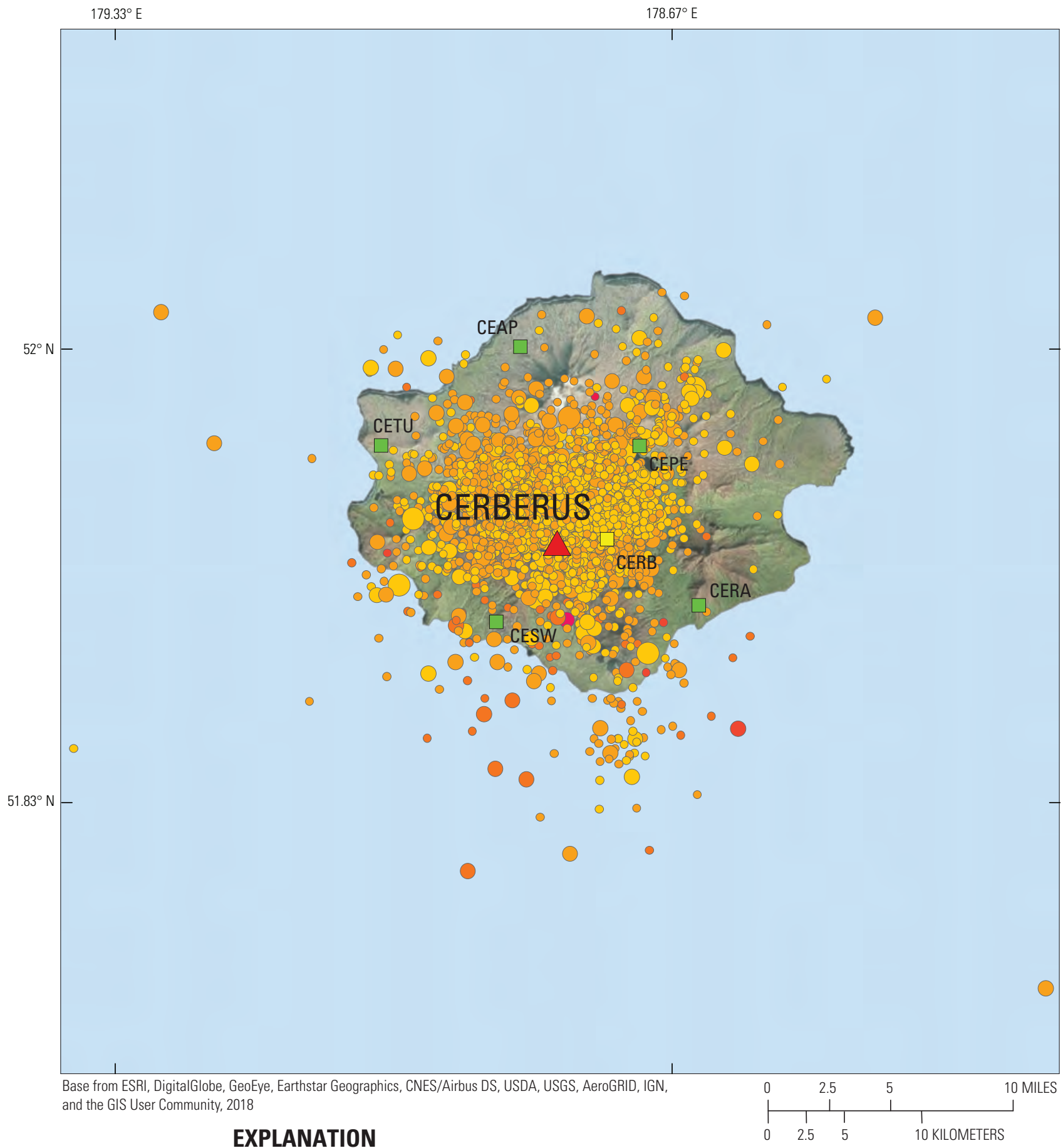

\section{Cerberus subnetwork}

Seismic stations

Single-component short period

$\square \quad$ Three-component broadband

$\square \quad$ Three-component short period

- Pressure sensor

Volcano

Magnitude

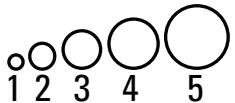

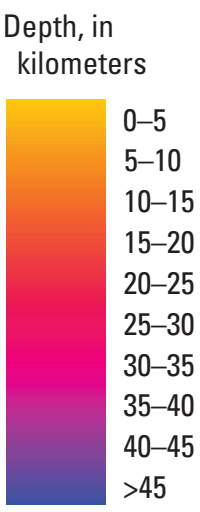

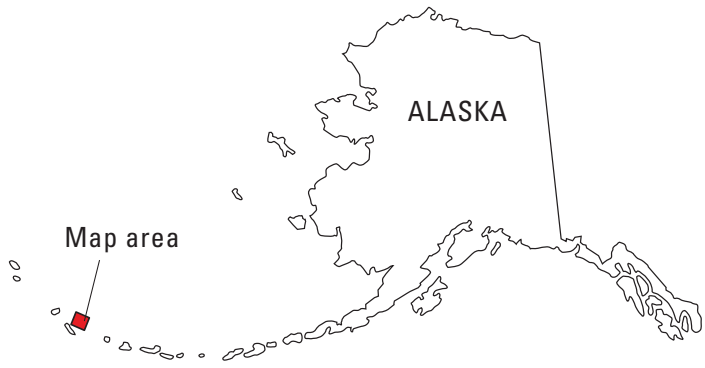

Figure 1.26. Map showing summary plot of earthquakes located by the Alaska Volcano Observatory with the seismic-monitoring subnetwork at Mount Cerberus in 2013-17. 


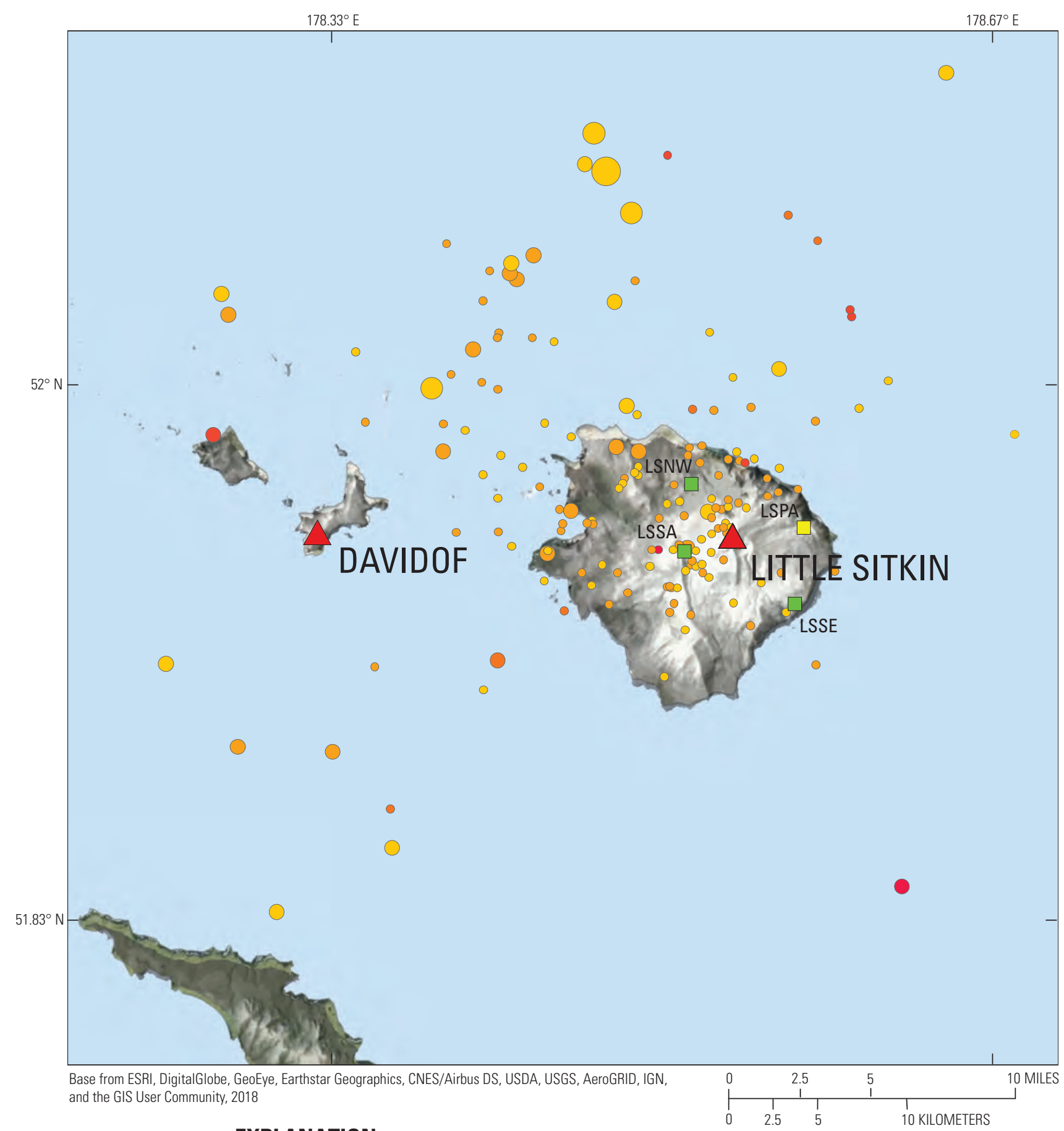

\section{EXPLANATION}

\section{Little Sitkin subnetwork}

Seismic stations

Single-component short period

$\square$ Three-component broadband

$\square \quad$ Three-component short period

- Pressure sensor

$\Delta$ Volcano

Magnitude

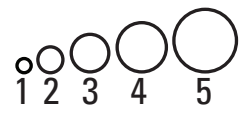

Depth, in

kilometers

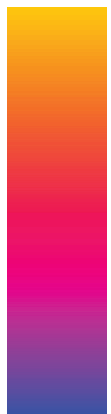

$0-5$

$5-10$

10-15

$15-20$

$20-25$

25-30

$30-35$

$35-40$

$40-45$

$>45$

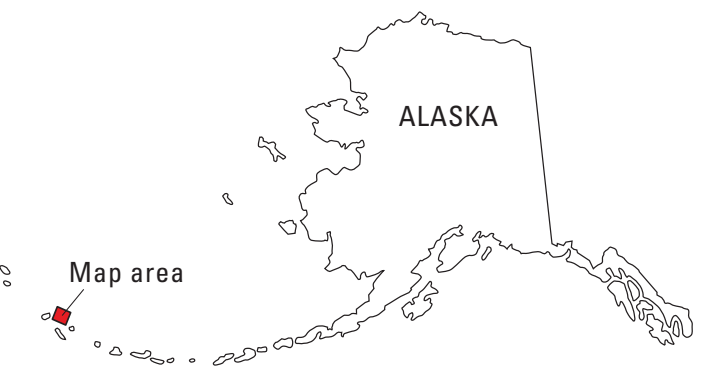

Figure 1.27. Map showing summary plot of earthquakes located by the Alaska Volcano Observatory with the seismic-monitoring subnetwork at Little Sitkin Volcano in 2013-17. 


\section{Appendix 2. Alaska Volcano Observatory Seismograph and Infrasound Stations in 2013-17}

This list includes station parameters for seismograph and infrasound stations operated by the Alaska Volcano Observatory. Metadata for all stations is included with this report. The open date is the date that data were first recorded, and the close date is the date that recording was stopped. Discounting temporary data outages, data are available for each listed station between the open and close date. Stations still in operation are indicated by a dash in the close date column. Unless noted, stations are single-component short-period seismograph stations. If a station has multiple elements, the location code is added to the station name-for example, AKS_01. Station locations in relation to volcanic centers are shown in appendix 1. 
Table 2.1. Seismograph and infrasound stations of the Akutan Peak subnetwork, operated by the Alaska Volcano Observatory.

[Date format is year/two-digit month/two-digit day; -, station is still in operation]

\begin{tabular}{|c|c|c|c|c|c|c|}
\hline Station ${ }^{1}$ & Latitude & Longitude & Elevation, in meters & Sensor $^{2}$ & Open date & Close date \\
\hline AHB & 54.1144 & -165.8177 & 447 & L-4 & $1996 / 07 / 24$ & - \\
\hline $\mathrm{AKBB}^{\mathrm{B}}$ & 54.0975 & -165.9338 & 310 & CMG-6T & $2005 / 07 / 05$ & - \\
\hline $\mathrm{AKGG}^{\mathrm{B}}$ & 54.1979 & -165.9936 & 326 & CMG-6T & $2003 / 06 / 27$ & - \\
\hline $\mathrm{AKLV}^{\mathrm{B}}$ & 54.1618 & -165.9576 & 551 & CMG-6T & $2003 / 07 / 02$ & - \\
\hline $\mathrm{AKMO}^{\mathrm{B}}$ & 54.0903 & -166.0126 & 277 & CMG-6T & $2003 / 06 / 25$ & - \\
\hline $\mathrm{AKRB}^{\mathrm{B}}$ & 54.1292 & -166.0708 & 334 & CMG-6T & $2003 / 06 / 29$ & - \\
\hline $\mathrm{AKS}^{3}$ & 54.1095 & -165.6987 & 213 & L-22 & $1996 / 07 / 24$ & - \\
\hline AKS_01 ${ }^{I}$ & 54.1105 & -165.6977 & 22 & Chap-M21/25 & $2011 / 07 / 14$ & - \\
\hline AKS_02 ${ }^{\mathrm{I}}$ & 54.1103 & -165.6962 & 224 & Chap-M21/25 & $2011 / 07 / 14$ & - \\
\hline AKS_03 ${ }^{1}$ & 54.1110 & -165.6970 & 218 & Chap-M21/25 & $2011 / 07 / 14$ & - \\
\hline AKS_04 ${ }^{\mathrm{I}}$ & 54.1105 & -165.6968 & 219 & Chap-M21/25 & $2011 / 07 / 14$ & - \\
\hline $\mathrm{AKSA}^{\mathrm{B}}$ & 54.1095 & -165.6987 & 213 & CMG-6T & $2011 / 07 / 14$ & - \\
\hline $\mathrm{AKT}^{\mathrm{B}}$ & 54.1349 & -165.7720 & 12 & CMG-40T & $1996 / 03 / 18$ & - \\
\hline AKV & 54.1253 & -165.9647 & 863 & L-4 & $1996 / 07 / 24$ & $2016 / 08 / 08$ \\
\hline$A K V^{B}$ & 54.1253 & -165.9647 & 863 & $\mathrm{TC} 120$ & $2016 / 08 / 08$ & - \\
\hline HSB & 54.1859 & -165.9144 & 497 & L-4 & $1996 / 07 / 24$ & - \\
\hline LVA & 54.1600 & -166.0358 & 457 & L-4 & $1996 / 07 / 24$ & $2016 / 08 / 08$ \\
\hline $\mathrm{LVA}^{\mathrm{B}}$ & 54.1600 & -166.0358 & 457 & $\mathrm{TC} 120$ & $2016 / 08 / 08$ & - \\
\hline ZRO & 54.0907 & -165.9800 & 446 & L-4 & $1996 / 07 / 24$ & - \\
\hline
\end{tabular}

${ }^{1}$ Station codes:

${ }^{3}$ Three-component short-period seismograph station.

${ }^{\mathrm{B}}$ Three-component broadband seismograph station.

IInfrasound station array element.

${ }^{L}$ Low-gain component of the seismograph station.

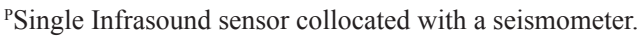

${ }^{\mathrm{R}}$ Station removed in 2013-17.

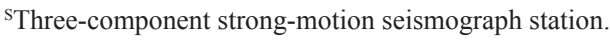

${ }^{\text {TA }}$ Seismograph station collocated with an U.S. Transportable Array station.

${ }^{2}$ Sensor codes:

Chap-M2: Chaparral Physics Model 2 infrasound sensors.

Chap-M21/25: Chaparral Physics Model 21/25 infrasound sensor.

Chap-M60/64: Chaparral Physics Model 60/64 infrasound sensor.

${ }^{\mathrm{C}} \mathrm{MG}-40 \mathrm{~T}$ : Güralp CMG-40T three-component broadband seismometer.

'MG-6T: Güralp CMG-6TD three-component broadband seismometer.

${ }^{E} \mathrm{~S}-\mathrm{T}$ : Kinemetrics Episensor ES-T strong-motion seismometer.

L-4: Sercel L-4 single-component vertical short-period seismometer (1 hertz).

L-4-3D: Sercel L-4 three component short-period seismometers (1 hertz).

L-22: Sercel L-22 three-component short-period seismometer (2 hertz).

s-13: Teledyne Geotech S-13 single-component vertical short-period seismometer (1 hertz).

${ }^{\mathrm{T}} \mathrm{C} 120-\mathrm{PH} 2$ : Nanometrics Trillium Compact three-component posthole broadband sensor.

${ }^{\mathrm{T}} \mathrm{C} 120$ : Nanometrics Trillium Compact three-component broadband seismometer.

T-40: Nanometrics Trillium 40 three-component broadband seismometer.

${ }^{V}$ DP-5: U.S. Geological Survey Cascades Volcano Observatory VDP5 infrasound sensor.

VDP-10: U.S. Geological Survey Cascades Volcano Observatory VDP10 infrasound sensor. 
Table 2.2. Seismograph stations of the Aniakchak Crater subnetwork, operated by the Alaska Volcano Observatory.

[See table 2.1 for explanation of superscripted footnotes. Date format is year/two-digit month/two-digit day; -, station is still in operation.]

\begin{tabular}{lcccccc}
\hline Station $^{1}$ & Latitude & Longitude & Elevation, in meters & Sensor $^{2}$ & Open date & Close date $^{2}$ \\
\hline ANNE & 56.9119 & -158.0610 & 705 & L-4 & $1997 / 07 / 18$ & - \\
ANNW & 56.9656 & -158.2170 & 816 & L-4 & $1997 / 07 / 18$ & - \\
ANON $^{3}$ & 56.9190 & -158.1737 & 445 & L-22 & $2000 / 07 / 09$ & $2017 / 07 / 05$ \\
ANON & 56.9190 & -158.1737 & 445 & L-4 & $2017 / 07 / 05$ & - \\
ANPB & 56.8016 & -158.2829 & 658 & L-4 & $1997 / 07 / 18$ & - \\
ANPK & 56.8409 & -158.1283 & 972 & L-4 & $1997 / 07 / 18$ & - \\
AZAC & 56.8947 & -158.2328 & 1,057 & L-4 & $2003 / 07 / 12$ & - \\
\hline
\end{tabular}

Table 2.3. Seismograph stations of the Augustine Volcano subnetwork, operated by the Alaska Volcano Observatory.

[See table 2.1 for explanation of superscripted footnotes. Date format is year/two-digit month/two-digit day; -, station is still in operation]

\begin{tabular}{lcccccc}
\hline Station $^{1}$ & Latitude & Longitude & Elevation, in meters & Sensor $^{2}$ & Open date & Close date \\
\hline AU22 $^{\text {SB }}$ & 59.3702 & -153.3573 & 105 & CMG-6T,ES-T & $2007 / 09 / 01$ & - \\
AUCH $^{\text {B }}$ & 59.3626 & -153.4447 & 916 & CMG-6T & $2014 / 08 / 20$ & - \\
AUE $^{\text {LP }}$ & 59.3711 & -153.3773 & 168 & S-13, Chap-M2 & $1980 / 10 / 29$ & - \\
AUH & 59.3632 & -153.4454 & 890 & S-13 & $1978 / 12 / 01$ & - \\
AUI $^{3}$ & 59.3345 & -153.4299 & 293 & S-13 & $1978 / 04 / 06$ & - \\
AUJA $^{\text {B }}$ & 59.3395 & -153.4227 & 376 & CMG-6T & $2013 / 08 / 20$ & - \\
AUJK & 59.3493 & -153.4106 & 377 & L-4 & $2011 / 08 / 16$ & - \\
AUL & 59.3816 & -153.4379 & 360 & S-13 & $1978 / 08 / 27$ & - \\
AUL & 59.3816 & -153.4379 & 360 & CMG-6T & $1997 / 08 / 27$ & - \\
AUNW & 59.3775 & -153.4790 & 160 & L-4 & $2006 / 03 / 15$ & - \\
AUP & 59.3627 & -153.4226 & 1,033 & L-4 & $1977 / 09 / 22$ & - \\
AUQ & 59.3549 & -153.4143 & 647 & CMG-6T & $2013 / 08 / 20$ & - \\
AUSB & 59.3330 & -153.4284 & 230 & CMG-6T & $2015 / 08 / 29$ & - \\
AUSS & 59.3539 & -153.4309 & 1,235 & CMG-6T & $2015 / 06 / 14$ & - \\
AUW & 59.3694 & -153.4730 & 276 & S-13 & $1986 / 10 / 17$ & - \\
AUWS $^{\text {B }}$ & 59.3585 & -153.4609 & 487 & CMG-6T & $2015 / 06 / 14$ & - \\
\hline
\end{tabular}

Table 2.4. Seismograph stations of the Mount Cerberus subnetwork, operated by the Alaska Volcano Observatory.

[See table 2.1 for explanation of superscripted footnotes. Date format is year/two-digit month/two-digit day; -, station is still in operation]

\begin{tabular}{lllcccc}
\hline Station $^{1}$ & Latitude & Longitude & Elevation, in meters & Sensor $^{2}$ & Open date & Close date $^{2}$ \\
\hline CEAP & 52.0012 & 179.5758 & 244 & L-4 & $2005 / 09 / 17$ & - \\
CEPE & 51.9646 & 179.6472 & 335 & L-4 & $2005 / 09 / 17$ & - \\
CERA & 51.9058 & 179.6826 & 305 & L-4 & $2005 / 09 / 26$ & - \\
CERB & 51.9302 & 179.6277 & 305 & L-22 & $2005 / 09 / 18$ & - \\
CESW & 51.8998 & 179.5613 & 238 & L-4 & $2005 / 09 / 18$ & - \\
CETU & 51.9649 & 179.4922 & 335 & L-4 & $2005 / 09 / 22$ & - \\
\hline
\end{tabular}


Table 2.5. Seismograph stations of the Mount Cleveland subnetwork, operated by the Alaska Volcano Observatory.

[See table 2.1 for explanation of superscripted footnotes. Date format is year/two-digit month/two-digit day; -, station is still in operation]

\begin{tabular}{|c|c|c|c|c|c|c|}
\hline Station $^{1}$ & Latitude & Longitude & Elevation, in meters & Sensor ${ }^{2}$ & Open date & Close date \\
\hline $\mathrm{CLCO}^{\mathrm{I}}$ & 52.7866 & -169.7229 & 137 & L-4 & $2014 / 08 / 09$ & - \\
\hline $\mathrm{CLCO}^{\mathrm{B}}$ & 52.7866 & -169.7229 & 137 & CMG-6T & $2014 / 08 / 09$ & - \\
\hline CLCO_02 ${ }^{\mathrm{I}}$ & 52.7871 & -169.7244 & 125 & VDP-5 & $2014 / 08 / 09$ & - \\
\hline CLCO_03' & 52.7875 & -169.7210 & 107 & VDP-5 & $2014 / 08 / 09$ & - \\
\hline CLCO_05 ${ }^{\mathrm{I}}$ & 52.7851 & -169.7250 & 113 & VDP-5 & $2014 / 08 / 09$ & - \\
\hline CLES $^{P}$ & 52.8235 & -169.8951 & 146 & $\begin{array}{c}\text { L-4, Chap-M21/25, } \\
\text { Chap-M60/64 }\end{array}$ & $2014 / 08 / 09$ & - \\
\hline CLES $^{\mathrm{B}}$ & 52.8235 & -169.8951 & 146 & TC120 & $2014 / 08 / 09$ & - \\
\hline
\end{tabular}

Table 2.6. Seismograph stations of the Mount Dutton subnetwork, operated by the Alaska Volcano Observatory.

[See table 2.1 for explanation of superscripted footnotes. Date format is year/two-digit month/two-digit day; -, station is still in operation]

\begin{tabular}{|c|c|c|c|c|c|c|}
\hline Station ${ }^{1}$ & Latitude & Longitude & Elevation, in meters & Sensor ${ }^{2}$ & Open date & Close date \\
\hline BLDY & 55.1936 & -162.7856 & 259 & L-4 & $1996 / 07 / 11$ & - \\
\hline DOL & 55.1488 & -161.8638 & 439 & L-4 & $1996 / 07 / 11$ & - \\
\hline DRR3 & 54.9660 & -162.2631 & 457 & L-4 & $1996 / 07 / 11$ & - \\
\hline DT1 & 55.1062 & -162.2830 & 198 & L-4 & $1991 / 06 / 21$ & - \\
\hline DTN & 55.1448 & -162.2590 & 396 & S-13 & $1988 / 07 / 16$ & - \\
\hline
\end{tabular}

Table 2.7. Seismograph stations of the Fourpeaked Mountain subnetwork, operated by the Alaska Volcano Observatory.

[See table 2.1 for explanation of superscripted footnotes. Date format is year/two-digit month/two-digit day; -, station is still in operation]

\begin{tabular}{|c|c|c|c|c|c|c|}
\hline Station ${ }^{1}$ & Latitude & Longitude & Elevation, in meters & Sensor ${ }^{2}$ & Open date & Close date \\
\hline $\mathrm{CDD}^{\mathrm{TA}}$ & 58.9289 & -153.6449 & 622 & S-13 & $1981 / 08 / 17$ & - \\
\hline FONWL & 58.8341 & -153.9204 & 905 & L-4, Chap-M2 & $2006 / 10 / 19$ & - \\
\hline FOSS $^{\mathrm{LP}}$ & 58.7987 & -153.6971 & 1,268 & L-4, Chap-M2 & $2006 / 10 / 19$ & - \\
\hline
\end{tabular}

Table 2.8. Seismograph stations of the Mount Gareloi subnetwork, operated by the Alaska Volcano Observatory.

[See table 2.1 for explanation of superscripted footnotes. Date format is year/two-digit month/two-digit day; -, station is still in operation]

\begin{tabular}{|c|c|c|c|c|c|c|}
\hline Station $^{1}$ & Latitude & Longitude & Elevation, in meters & Sensor $^{2}$ & Open date & Close date \\
\hline GAEA & 51.7819 & -178.7488 & 326 & L-4 & $2003 / 08 / 30$ & - \\
\hline GAKI & 51.5534 & -178.8140 & 99 & L-4 & $2003 / 09 / 01$ & - \\
\hline GANE & 51.8178 & -178.7787 & 325 & L-4 & $2003 / 09 / 02$ & - \\
\hline GANO & 51.8192 & -178.8058 & 451 & L-4 & $2003 / 09 / 02$ & - \\
\hline
\end{tabular}


Table 2.9. Seismograph stations of the Great Sitkin Volcano subnetwork, operated by the Alaska Volcano Observatory.

[See table 2.1 for explanation of superscripted footnotes. Date format is year/two-digit month/two-digit day; -, station is still in operation]

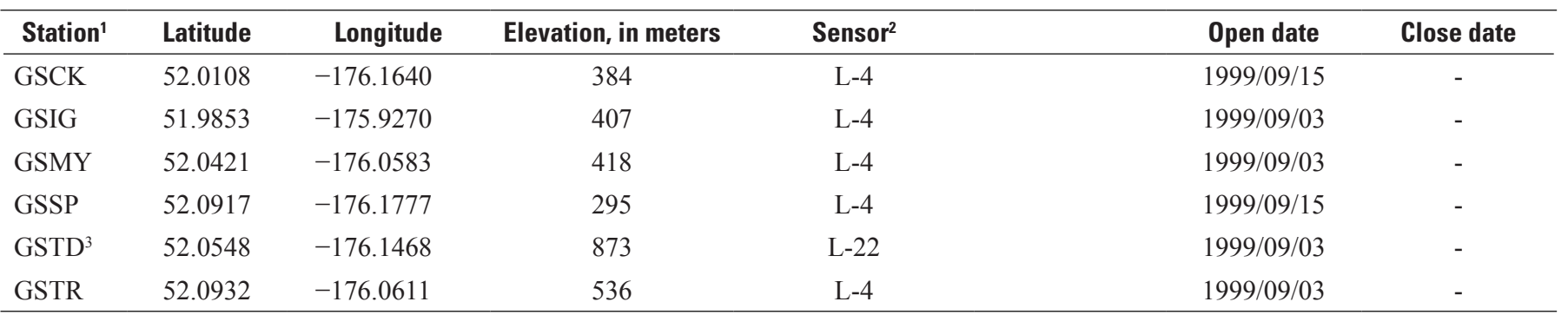

Table 2.10. Seismograph stations of the lliamna Volcano subnetwork, operated by the Alaska Volcano Observatory.

[See table 2.1 for explanation of superscripted footnotes. Date format is year/two-digit month/two-digit day; -, station is still in operation]

\begin{tabular}{|c|c|c|c|c|c|c|}
\hline Station ${ }^{1}$ & Latitude & Longitude & Elevation, in meters & Sensor $^{2}$ & Open date & Close date \\
\hline ILI & 60.0807 & -152.9606 & 771 & L-4 & $1987 / 09 / 15$ & - \\
\hline ILNE $^{3}$ & 60.0573 & -153.0635 & 1,614 & L-22 & $2016 / 09 / 27$ & \\
\hline $\mathrm{ILS}^{3}$ & 59.9570 & -153.0703 & 1,125 & S-13 & $1996 / 08 / 28$ & - \\
\hline ILS $^{\text {в }}$ & 59.9570 & -153.0703 & 1,125 & CMG-6T & $2015 / 09 / 01$ & $2017 / 08 / 22$ \\
\hline ILS $^{\mathrm{B}}$ & 59.9570 & -153.0703 & 1,125 & TC120-PH2 & $2017 / 08 / 22$ & - \\
\hline ILSW $^{\text {B }}$ & 59.9832 & -153.1420 & 1,318 & TC120 & $2015 / 09 / 10$ & \\
\hline ILW & 60.0592 & -153.1392 & 1,646 & S-13 & $1994 / 09 / 09$ & - \\
\hline $\mathrm{ILW}^{\mathrm{B}}$ & 60.0592 & -153.1392 & 1,646 & CMG-6T & $2013 / 08 / 20$ & $2016 / 09 / 27$ \\
\hline ILW $^{3}$ & 60.0592 & -153.1392 & 1,646 & L-22 & $2016 / 09 / 27$ & - \\
\hline INE & 60.0599 & -153.0644 & 1,634 & S-13 & $1990 / 08 / 29$ & $2016 / 08 / 31$ \\
\hline $\mathrm{IVE}^{3}$ & 60.0163 & -153.0185 & 1,173 & S-13, L-22 & $1996 / 08 / 29$ & - \\
\hline $\mathrm{IVE}^{\mathrm{B}}$ & 60.0163 & -153.0185 & 1,173 & CMG-6T & $2013 / 08 / 20$ & \\
\hline IVS & 60.0086 & -153.0830 & 2,332 & S-13 & $1990 / 08 / 29$ & - \\
\hline
\end{tabular}

Table 2.11. Seismograph stations of the Kanaga Volcano subnetwork, operated by the Alaska Volcano Observatory.

[See table 2.1 for explanation of superscripted footnotes. Date format is year/two-digit month/two-digit day; -, station is still in operation]

\begin{tabular}{lcccccc}
\hline Station $^{1}$ & Latitude & Longitude & Elevation, in meters & Sensor $^{2}$ & Open date & Close date $^{2}$ \\
\hline KICM & 51.9178 & -177.1973 & 183 & L-4 & $1999 / 09 / 15$ & - \\
KIKV & 51.8777 & -177.1724 & 411 & L-4 & $1999 / 09 / 15$ & - \\
KIMD & 51.7605 & -177.2369 & 183 & L-4 & $1999 / 09 / 15$ & - \\
KINC & 51.9303 & -177.1296 & 198 & L-4 & $1999 / 09 / 15$ & - \\
KIRH & 51.8985 & -177.0955 & 309 & L-4 & $1999 / 09 / 03$ & - \\
KIWB & 51.8520 & -177.1528 & 244 & L-4 & $1999 / 09 / 03$ & - \\
\hline
\end{tabular}


Table 2.12. Seismograph stations of the Katmai volcanic cluster subnetwork, operated by the Alaska Volcano Observatory.

[See table 2.1 for explanation of superscripted footnotes. Date format is year/two-digit month/two-digit day; -, station is still in operation]

\begin{tabular}{|c|c|c|c|c|c|c|}
\hline Station $^{1}$ & Latitude & Longitude & Elevation, in meters & Sensor $^{2}$ & Open date & Close date \\
\hline $\mathrm{ACH}^{3}$ & 58.2100 & -155.3281 & 960 & $\mathrm{~L}-22$ & $1996 / 07 / 25$ & $2017 / 08 / 18$ \\
\hline $\mathrm{ACH}^{\mathrm{B}}$ & 58.2100 & -155.3281 & 960 & TC120-PH2 & $2017 / 08 / 21$ & - \\
\hline ANCK & 58.1981 & -155.4961 & 869 & L-4 & $1996 / 07 / 25$ & $2016 / 08 / 16$ \\
\hline $\mathrm{ANCK}^{\mathrm{B}}$ & 58.1981 & -155.4961 & 869 & $\mathrm{TC} 120$ & $2016 / 07 / 16$ & - \\
\hline CAHL & 58.0518 & -155.3036 & 807 & L-4 & $1996 / 07 / 25$ & - \\
\hline $\mathrm{CNTC}^{\mathrm{TA}}$ & 58.2638 & -155.8858 & 1,158 & L-4 & $1996 / 07 / 25$ & - \\
\hline KABR & 58.1304 & -154.9716 & 940 & L-4 & $1998 / 08 / 12$ & - \\
\hline $\mathrm{KABU}^{\mathrm{B}}$ & 58.2702 & -155.2843 & 1,065 & CMT-6T & $2004 / 08 / 01$ & $2017 / 08 / 17$ \\
\hline $\mathrm{KABU}^{\mathrm{B}}$ & 58.2702 & -155.2843 & 1,065 & TC120-PH2 & $2017 / 08 / 17$ & - \\
\hline $\mathrm{KAHC}^{\mathrm{TA}}$ & 58.6483 & -155.0081 & 1,250 & L-4 & $1998 / 10 / 12$ & - \\
\hline KAHG & 58.4933 & -154.5484 & 923 & L-4 & $1998 / 10 / 12$ & $2017 / 08 / 21$ \\
\hline $\mathrm{KAHG}^{\mathrm{B}}$ & 58.4933 & -154.5484 & 923 & TC120-PH2 & $2017 / 08 / 21$ & - \\
\hline KAIC & 58.4843 & -155.0479 & 734 & L-4 & $1998 / 10 / 12$ & - \\
\hline $\mathrm{KAKN}^{\mathrm{B}}$ & 58.2963 & -155.0623 & 1,049 & CMG-6T & $2004 / 08 / 01$ & $2017 / 08 / 23$ \\
\hline $\mathrm{KAKN}^{\mathrm{B}}$ & 58.2963 & -155.0623 & 1,049 & TC120-PH2 & $2017 / 08 / 23$ & - \\
\hline $\mathrm{KAPH}^{3}$ & 58.5961 & -154.3489 & 907 & L-22 & $1998 / 10 / 12$ & - \\
\hline KARR & 58.4971 & -154.7054 & 610 & L-4 & 1998/10/12 & - \\
\hline KAWH & 58.3830 & -154.8013 & 777 & L-4 & $1998 / 10 / 12$ & - \\
\hline KBM & 58.2743 & -155.2038 & 732 & L-4 & $1991 / 07 / 22$ & - \\
\hline KCE & 58.2426 & -155.1854 & 777 & L-4 & $1991 / 07 / 22$ & - \\
\hline $\mathrm{KCG}^{3}$ & 58.3069 & -155.1135 & 762 & L-22 & $1988 / 08 / 01$ & - \\
\hline KEL & 58.4393 & -155.7428 & 975 & L-4 & $1988 / 08 / 01$ & - \\
\hline KJL & 58.0533 & -155.5753 & 792 & L-4 & $1996 / 07 / 25$ & - \\
\hline KVT & 58.3810 & -155.2971 & 457 & L-4 & $1988 / 08 / 01$ & - \\
\hline MGLS & 58.1336 & -155.1629 & 472 & L-4 & $1996 / 07 / 25$ & - \\
\hline
\end{tabular}

Table 2.13. Seismograph stations of the Korovin Volcano subnetwork, operated by the Alaska Volcano Observatory.

[See table 2.1 for explanation of superscripted footnotes. Date format is year/two-digit month/two-digit day; -, station is still in operation]

\begin{tabular}{lcccccc}
\hline \multicolumn{1}{c}{ Station $^{1}$} & Latitude & Longitude & Elevation, in meters & Sensor $^{2 *}$ & Open date & Close date $^{*}$ \\
\hline KOFP & 52.2740 & -174.0992 & 662 & L-4 & $2004 / 07 / 02$ & - \\
KOKL & 52.3221 & -174.2022 & 758 & L-4 & $2004 / 07 / 05$ & - \\
KOKV $^{3}$ & 52.3603 & -174.1673 & 776 & L-22 & $2004 / 07 / 05$ & - \\
KONE & 52.3925 & -174.1213 & 253 & L-4 & $2004 / 07 / 10$ & - \\
KONW & 52.3954 & -174.2125 & 334 & L-4 & $2004 / 07 / 04$ & - \\
KOSE & 52.3447 & -174.0505 & 625 & L-4 & $2004 / 07 / 07$ & - \\
KOWE & 52.3646 & -174.2527 & 527 & L-4 & $2004 / 07 / 06$ & - \\
\hline
\end{tabular}


Table 2.14. Seismograph stations of the Little Sitkin Volcano subnetwork, operated by the Alaska Volcano Observatory.

[See table 2.1 for explanation of superscripted footnotes. Date format is year/two-digit month/two-digit day; -, station is still in operation]

\begin{tabular}{lcccccc}
\hline Station $^{1}$ & Latitude & Longitude & Elevation, in meters & Sensor $^{2}$ & Open date & Close date \\
\hline LSNW & 51.9693 & 178.5148 & 290 & L-4 & $2005 / 09 / 30$ & - \\
LSPA $^{3}$ & 51.9557 & 178.5714 & 335 & L-22 & $2005 / 09 / 30$ & - \\
LSSA & 51.9484 & 178.5112 & 549 & L-4 & $2005 / 09 / 28$ & - \\
LSSE & 51.9320 & 178.5670 & 335 & L-4 & $2005 / 09 / 27$ & - \\
\hline
\end{tabular}

Table 2.15. Seismograph stations of the Makushin Volcano subnetwork, operated by the Alaska Volcano Observatory.

[See table 2.1 for explanation of superscripted footnotes. Date format is year/two-digit month/two-digit day; -, station is still in operation]

\begin{tabular}{|c|c|c|c|c|c|c|}
\hline Station $^{1}$ & Latitude & Longitude & Elevation, in meters & Sensor $^{2}$ & Open date & Close date \\
\hline MAPS $^{B}$ & 53.8082 & -166.9407 & 333 & CMG-6TD & $2012 / 08 / 03$ & - \\
\hline MCIR & 53.9505 & -166.8942 & 800 & L-4 & $1996 / 07 / 25$ & $2016 / 08 / 08$ \\
\hline $\mathrm{MCIR}^{\mathrm{B}}$ & 53.9505 & -166.8942 & 800 & TC120 & $2016 / 08 / 08$ & - \\
\hline MGOD & 53.7938 & -166.8780 & 650 & L-4 & $1996 / 07 / 25$ & - \\
\hline $\mathrm{MGOD}^{\mathrm{B}}$ & 53.7938 & -166.8780 & 650 & CMG-6T & $2012 / 08 / 03$ & - \\
\hline MNAT & 53.8829 & -166.6856 & 390 & L-4 & $1996 / 07 / 25$ & - \\
\hline MNAT $^{\mathrm{B}}$ & 53.8829 & -166.6856 & 390 & CMG-6T & $2012 / 08 / 03$ & - \\
\hline MREP & 53.8096 & -166.7476 & 785 & L-4 & $2002 / 01 / 01$ & - \\
\hline $\mathrm{MSW}^{3}$ & 53.9148 & -166.7880 & 423 & L-22 & $1996 / 07 / 25$ & $2016 / 08 / 07$ \\
\hline $\mathrm{MSW}^{\mathrm{B}}$ & 53.9148 & -166.7880 & 423 & CMG-6T & $2011 / 08 / 04$ & - \\
\hline $\mathrm{MSW}^{\mathrm{BP}}$ & 53.9148 & -166.7880 & 423 & $\begin{array}{l}\text { TC120, Chap- } \\
\text { M21/25 }\end{array}$ & $2016 / 08 / 07$ & - \\
\hline MTBL & 53.9680 & -166.6813 & 810 & L-4 & $1996 / 07 / 25$ & $2016 / 08 / 07$ \\
\hline MTBL $^{\mathrm{B}}$ & 53.9680 & -166.6813 & 810 & TC120 & $2016 / 07 / 07$ & - \\
\hline
\end{tabular}

Table 2.16. Seismograph and infrasound stations of the Okmok Caldera subnetwork, operated by the Alaska Volcano Observatory.

[See table 2.1 for explanation of superscripted footnotes. Date format is year/two-digit month/two-digit day; -, station is still in operation]

\begin{tabular}{|c|c|c|c|c|c|c|}
\hline Station ${ }^{1}$ & Latitude & Longitude & Elevation, in meters & Sensor ${ }^{2}$ & Open date & Close date \\
\hline OKAK & 53.4113 & -168.3600 & 165 & L-4 & $2005 / 07 / 11$ & - \\
\hline $\mathrm{OKCE}^{\mathrm{B}}$ & 53.4260 & -168.1663 & 515 & CMG-6T & 2003/01/09 & - \\
\hline $\mathrm{OKCF}$ & 53.3948 & -168.1382 & 685 & $\mathrm{~L}-4$ & 2003/01/09 & - \\
\hline OKER & 53.4536 & -168.0513 & 956 & L-4 & 2003/01/09 & - \\
\hline $\mathrm{OKFG}^{\mathrm{B}}$ & 53.4107 & -167.9115 & 201 & CMG-6T & 2003/01/09 & - \\
\hline OKID & 53.4764 & -167.8182 & 437 & L-4 & 2003/01/09 & - \\
\hline OKIF_01 ${ }^{\mathrm{I}}$ & 53.4108 & -167.9143 & 210 & Chap-M21/25 & 2010/09/01 & - \\
\hline OKIF_02 ${ }^{\mathrm{I}}$ & 53.4100 & -167.9137 & 212 & Chap-M21/25 & 2010/09/01 & - \\
\hline OKIF_03 ${ }^{\mathrm{I}}$ & 53.4100 & -167.9150 & 213 & Chap-M21/25 & 2010/09/01 & - \\
\hline OKIF_04 ${ }^{\mathrm{I}}$ & 53.4103 & -167.9144 & 215 & Chap-M21/25 & 2010/09/01 & - \\
\hline $\mathrm{OKNC}^{\mathrm{B}}$ & 53.4559 & -168.1257 & 404 & CMG-6T & 2010/09/01 & - \\
\hline OKRE & 53.5192 & -168.1661 & 422 & L-4 & 2003/01/09 & - \\
\hline $\mathrm{OKSO}^{\mathrm{B}}$ & 53.3565 & -168.1619 & 460 & CMG-6T & $2004 / 09 / 01$ & - \\
\hline OKSP & 53.2516 & -168.2925 & 608 & L-4 & 2003/01/09 & - \\
\hline OKTU & 53.3829 & -168.0431 & 646 & $\mathrm{~L}-4$ & 2003/01/09 & - \\
\hline OKWE & 53.4711 & -168.2418 & 445 & L-4 & 2003/01/09 & - \\
\hline OKWR & 53.4337 & -168.2076 & 1,017 & L-4 & $2003 / 01 / 09$ & - \\
\hline
\end{tabular}


Table 2.17. Seismograph stations of the Pavlof Volcano subnetwork, operated by the Alaska Volcano Observatory.

[See table 2.1 for explanation of superscripted footnotes. Date format is year/two-digit month/two-digit day; -, station is still in operation]

\begin{tabular}{|c|c|c|c|c|c|c|}
\hline Station ${ }^{1}$ & Latitude & Longitude & Elevation, in meters & Sensor $^{2}$ & Open date & Close date \\
\hline $\mathrm{BLHA}^{\mathrm{TA}}$ & 55.7038 & -162.0611 & 411 & L-4 & $1996 / 07 / 11$ & - \\
\hline HAG & 55.3170 & -161.9045 & 516 & L-4 & $1996 / 07 / 11$ & - \\
\hline PN7A & 55.4329 & -161.9973 & 838 & L-4 & $1996 / 07 / 11$ & $2016 / 07 / 04$ \\
\hline PN7A ${ }^{3}$ & 55.4329 & -161.9973 & 838 & L-22 & $2016 / 07 / 04$ & $2017 / 07 / 09$ \\
\hline PS1A & 55.4201 & -161.7437 & 283 & L-4 & $1996 / 07 / 11$ & - \\
\hline $\mathrm{PS} 1 \mathrm{~A}^{\mathrm{BP}}$ & 55.4201 & -161.7437 & 283 & $\begin{array}{c}\text { TC120-PH2, } \\
\text { Chap-M60/64 }\end{array}$ & $2017 / 07 / 06$ & - \\
\hline PS4A & 55.3460 & -161.8567 & 322 & L-4 & $1996 / 07 / 11$ & - \\
\hline PV6A ${ }^{3 p}$ & 55.5070 & -161.9714 & 352 & $\begin{array}{c}\text { L-22, Chap- } \\
\text { M60/64 }\end{array}$ & $2016 / 07 / 04$ & - \\
\hline PVV & 55.3732 & -161.7919 & 173 & L-4 & $1996 / 07 / 11$ & - \\
\hline $\mathrm{PVV}^{3}$ & 55.3732 & -161.7919 & 173 & L-22 & $2017 / 07 / 07$ & - \\
\hline
\end{tabular}

Table 2.18. Seismograph stations of the Redoubt Volcano subnetwork, operated by the Alaska Volcano Observatory. [See table 2.1 for explanation of superscripted footnotes. Date format is year/two-digit month/two-digit day; -, station is still in operation]

\begin{tabular}{|c|c|c|c|c|c|c|}
\hline Station $^{1}$ & Latitude & Longitude & Elevation, in meters & Sensor $^{2}$ & Open date & Close date \\
\hline $\mathrm{DFR}^{\mathrm{P}}$ & 60.5913 & -152.6882 & 1,090 & L-4, Chap-M2 & $1988 / 08 / 15$ & - \\
\hline $\mathrm{NCT}$ & 60.5615 & -152.9316 & 1,120 & L-4 & $1988 / 08 / 14$ & - \\
\hline $\mathrm{RDDF}^{\mathrm{B}}$ & 60.5912 & -152.6883 & 1,134 & CMG-6T & $2010 / 01 / 11$ & - \\
\hline RDDR & 60.5843 & -152.5887 & 905 & L-4 & 2009/07/01 & - \\
\hline $\mathrm{RDSO}^{\mathrm{B}}$ & 60.4536 & -152.7453 & 1,557 & CMG-6T & $2011 / 08 / 29$ & - \\
\hline RDT & 60.5726 & -152.4075 & 930 & L-4 & $1971 / 08 / 09$ & - \\
\hline $\mathrm{RDWB}^{\mathrm{B}}$ & 60.4875 & -152.8424 & 1,546 & CMG-6T & $2009 / 02 / 24$ & - \\
\hline $\mathrm{RED}^{3}$ & 60.4196 & -152.7742 & 1,071 & L-4 & $1990 / 08 / 30$ & $2014 / 07 / 12$ \\
\hline RSO & 60.4616 & -152.7560 & 1,921 & L-4 & 1990/03/01 & - \\
\hline
\end{tabular}


Table 2.19. Seismograph stations of the Shishaldin Volcano subnetwork, operated by the Alaska Volcano Observatory.

[See table 2.1 for explanation of superscripted footnotes. Date format is year/two-digit month/two-digit day; -, station is still in operation]

\begin{tabular}{|c|c|c|c|c|c|c|}
\hline Station ${ }^{1}$ & Latitude & Longitude & Elevation, in meters & Sensor ${ }^{2}$ & Open date & Close date \\
\hline BRPK & 54.6446 & -163.7428 & 393 & L-4 & $1997 / 07 / 27$ & - \\
\hline ISLZ & 54.7251 & -163.7130 & 631 & L-4 & $2008 / 08 / 17$ & - \\
\hline ISNN & 54.8314 & -163.7804 & 466 & L-4 & $1997 / 07 / 27$ & - \\
\hline $\mathrm{ISNN}^{3}$ & 54.8314 & -163.7804 & 466 & L-22 & $2016 / 07 / 29$ & - \\
\hline $\operatorname{SSLN}^{\mathrm{P}}$ & 54.8109 & -163.9979 & 637 & L-4, Chap-M2 & $1997 / 07 / 27$ & - \\
\hline $\operatorname{SSLN}^{\mathrm{B}}$ & 54.8109 & -163.9979 & 637 & CMG-6T & $2014 / 08 / 07$ & - \\
\hline SSLS $^{3}$ & 54.7111 & -164.0008 & 817 & L-22 & $1997 / 07 / 27$ & - \\
\hline SSLS $^{\mathrm{B}}$ & 54.7111 & -164.0008 & 817 & CMG-6T & $2014 / 08 / 07$ & - \\
\hline SSLW & 54.7709 & -164.1234 & 636 & L-4 & $1997 / 07 / 27$ & - \\
\hline
\end{tabular}

Table 2.20. Seismograph stations of the Mount Spurr subnetwork, operated by the Alaska Volcano Observatory.

[See table 2.1 for explanation of superscripted footnotes. Date format is year/two-digit month/two-digit day; -, station is still in operation]

\begin{tabular}{|c|c|c|c|c|c|c|}
\hline Station $^{1}$ & Latitude & Longitude & Elevation, in meters & Sensor ${ }^{2}$ & Open date & Close date \\
\hline BGL & 61.2663 & -152.3913 & 1,127 & L-4 & $1989 / 08 / 13$ & - \\
\hline BKG & 61.0696 & -152.2650 & 1,009 & L-4 & $1991 / 07 / 01$ & - \\
\hline CKL & 61.1958 & -152.3400 & 1,281 & L-4 & $1989 / 08 / 05$ & - \\
\hline $\mathrm{CKN}$ & 61.2234 & -152.1838 & 735 & L-4 & $1991 / 09 / 19$ & - \\
\hline $\mathrm{CP} 2$ & 61.2636 & -152.2441 & 1,981 & L-4 & $1992 / 10 / 23$ & - \\
\hline $\mathrm{CRP}^{3}$ & 61.2664 & -152.1578 & 1,622 & L-4 & $1981 / 08 / 26$ & - \\
\hline NCG & 61.4031 & -152.1590 & 1,244 & L-4 & $1989 / 08 / 06$ & - \\
\hline $\mathrm{SPBG}^{\mathrm{B}}$ & 61.2591 & -152.3722 & 1,087 & CMG-6T & $2004 / 09 / 09$ & - \\
\hline $\mathrm{SPCG}^{\mathrm{B}}$ & 61.2913 & -152.0228 & 1,329 & CMG-6T & $2004 / 09 / 08$ & - \\
\hline $\mathrm{SPNN}^{\mathrm{B}}$ & 61.3662 & -152.7012 & 1,666 & CMG-6T & $2011 / 08 / 01$ & - \\
\hline SPU & 61.1811 & -152.0566 & 800 & L-4 & $1971 / 08 / 10$ & - \\
\hline SPU $^{\mathrm{B}}$ & 61.1811 & -152.0566 & 800 & TC120-PH2 & $2017 / 08 / 10$ & - \\
\hline SPWE & 61.2728 & -152.5614 & 1,327 & L-4 & $2004 / 08 / 18$ & - \\
\hline
\end{tabular}


Table 2.21. Seismograph stations of the Tanaga Volcano subnetwork, operated by the Alaska Volcano Observatory.

[See table 2.1 for explanation of superscripted footnotes. Date format is year/two-digit month/two-digit day; -, station is still in operation]

\begin{tabular}{lcccccc}
\hline \multicolumn{1}{c}{ Station $^{1}$} & Latitude & Longitude & Elevation, in meters & Sensor $^{2}$ & Open date & Close date \\
\hline TACS & 51.8621 & -178.1414 & 918 & L-4 & $2003 / 08 / 28$ & - \\
TAFL & 51.7555 & -177.8998 & 186 & L-4 & $2003 / 08 / 28$ & - \\
TAFP $^{3}$ & 51.8990 & -177.9853 & 440 & L-22 & $2003 / 08 / 27$ & - \\
TANO & 51.9146 & -178.1228 & 269 & L-4 & $2003 / 08 / 24$ & - \\
TAPA & 51.8144 & -177.8148 & 640 & L-4 & $2003 / 08 / 27$ & - \\
TASE & 51.8339 & -178.0390 & 682 & L-4 & $2003 / 08 / 24$ & - \\
\hline
\end{tabular}

Table 2.22. Seismograph stations of the Ugashik-Peulik Volcano subnetwork, operated by the Alaska Volcano Observatory.

[See table 2.1 for explanation of superscripted footnotes. Date format is year/two-digit month/two-digit day; -, station is still in operation]

\begin{tabular}{lrccccc}
\hline \multicolumn{1}{c}{ Station $^{1}$} & Latitude & Longitude & Elevation, in meters & Sensor $^{2}$ & Open date & Close date $^{\text { }}$ \\
\hline PLBL & 57.6991 & -156.8210 & 461 & L-4 & $2004 / 08 / 01$ & - \\
PLK1 & 57.8012 & -156.6093 & 78 & L-4 & $2004 / 08 / 01$ & - \\
PLK2 & 57.7635 & -156.3264 & 401 & L-4 & $2004 / 08 / 01$ & - \\
PLK3 & 57.6880 & -156.2695 & 494 & L-22 & $2004 / 08 / 01$ & - \\
PLK4 & 57.6314 & -156.3598 & 1,031 & L-4 & $2004 / 08 / 01$ & - \\
PLK5 & 57.9970 & -156.8798 & 49 & L-4 & $2004 / 08 / 01$ & - \\
PLWL & 58.0442 & -156.3434 & 585 & L-4 & $2004 / 08 / 01$ & - \\
\hline
\end{tabular}

Table 2.23. Seismograph stations of the Mount Veniaminof subnetwork, operated by the Alaska Volcano Observatory.

[See table 2.1 for explanation of superscripted footnotes. Date format is year/two-digit month/two-digit day; -, station is still in operation]

\begin{tabular}{lrccccc}
\hline \multicolumn{1}{c}{ Station $^{1}$} & Latitude & Longitude & Elevation, in meters & Sensor $^{2}$ & Open date & Close date $^{\text {B }}$ \\
\hline BPBC & 56.5889 & -158.4547 & 584 & L-4 & $2002 / 10 / 03$ & - \\
VNFG $^{\text {TA }}$ & 56.2849 & -159.5532 & 1,068 & L-4 & $2002 / 06 / 20$ & - \\
VNHG & 56.2203 & -159.1663 & 966 & L-4 & $2002 / 02 / 06$ & - \\
VNKR & 56.0304 & -159.3699 & 620 & L-4 & $2002 / 02 / 06$ & - \\
VNNF & 56.2829 & -159.3181 & 1,153 & L-4 & $2002 / 06 / 20$ & - \\
VNSG & 56.1250 & -159.0875 & 761 & L-4 & $2002 / 02 / 06$ & - \\
VNSS & 56.2259 & -159.4569 & 1,733 & L-4 & $2002 / 02 / 06$ & - \\
VNSW & 56.0712 & -159.5606 & 716 & L-4 & $2002 / 06 / 20$ & - \\
VNWF & 56.1509 & -159.5643 & 1,095 & L-4 & $2002 / 02 / 06$ & - \\
\hline
\end{tabular}


Table 2.24. Seismograph stations of the Westdahl Peak subnetwork, operated by the Alaska Volcano Observatory.

[See table 2.1 for explanation of superscripted footnotes. Date format is year/two-digit month/two-digit day; -, station is still in operation]

\begin{tabular}{|c|c|c|c|c|c|c|}
\hline Station ${ }^{1}$ & Latitude & Longitude & Elevation, in meters & Sensor $^{2}$ & Open date & Close date \\
\hline WEBT & 54.5902 & -164.7550 & 467 & L-4 & $2008 / 08 / 02$ & - \\
\hline WEBT $^{\mathrm{B}}$ & 54.5902 & -164.7550 & 467 & TC120-PH2 & $2017 / 06 / 27$ & - \\
\hline WECS & 54.5300 & -164.7796 & 642 & L-4 & $2008 / 08 / 04$ & - \\
\hline WECS $^{\mathrm{B}}$ & 54.5300 & -164.7796 & 642 & CMG-6T & $2015 / 06 / 29$ & - \\
\hline WESE & 54.4723 & -164.5860 & 953 & L-4 & $1998 / 08 / 28$ & - \\
\hline WESN & 54.5761 & -164.5804 & 549 & L-4 & $1998 / 10 / 17$ & - \\
\hline WESP ${ }^{3}$ & 54.4926 & -164.7233 & 937 & $\mathrm{~L}-22$ & $2008 / 07 / 31$ & - \\
\hline WTUG & 54.8466 & -164.3873 & 636 & L-4 & $1998 / 10 / 17$ & - \\
\hline
\end{tabular}

Table 2.25. Seismograph stations of the Mount Wrangell subnetwork, operated by the Alaska Volcano Observatory.

[See table 2.1 for explanation of superscripted footnotes. Date format is year/two-digit month/two-digit day; -, station is still in operation]

\begin{tabular}{|c|c|c|c|c|c|c|}
\hline Station ${ }^{1}$ & Latitude & Longitude & Elevation, in meters & Sensor ${ }^{2}$ & Open date & Close date \\
\hline $\mathrm{WACK}^{3}$ & 61.9858 & -144.3305 & 2,280 & L-22 & $2000 / 07 / 31$ & $2016 / 07 / 17$ \\
\hline $\mathrm{WACK}^{\mathrm{B}}$ & 61.9858 & -144.3305 & 2,280 & $\mathrm{TC} 120$ & $2016 / 07 / 17$ & - \\
\hline WANC & 62.0027 & -144.0720 & 4,190 & L-4 & $2000 / 07 / 31$ & - \\
\hline WASW & 61.9277 & -144.1745 & 2,196 & L-4 & $2001 / 08 / 03$ & $2016 / 07 / 17$ \\
\hline WASW $^{3}$ & 61.9277 & -144.1745 & 2,196 & L-22 & $2016 / 07 / 17$ & - \\
\hline WAZA & 62.0746 & -144.1544 & 2,531 & $\mathrm{~L}-4$ & $2001 / 08 / 03$ & $2016 / 10 / 05$ \\
\hline $\mathrm{WAZA}^{\mathrm{B}}$ & 62.0746 & -144.1544 & 2,531 & $\mathrm{TC} 120$ & $2017 / 07 / 29$ & - \\
\hline
\end{tabular}




\section{Catalog of Earthquake Parameters and Description of Seismograph and Infrasound Stations at Alaskan Volcanoes}

Table 2.26. Regional seismograph and infrasound stations operated by the Alaska Volcano Observatory.

[See table 2.1 for explanation of superscripted footnotes. Date format is year/two-digit month/two-digit day; -, station is still in operation]

\begin{tabular}{|c|c|c|c|c|c|c|}
\hline Station ${ }^{1}$ & Latitude & Longitude & Elevation, in meters & Sensor $^{2}$ & Open date & Close date \\
\hline $\mathrm{ADAG}$ & 51.9791 & -176.6037 & 286 & L-4 & $1999 / 09 / 15$ & - \\
\hline $\mathrm{ADAK}^{\mathrm{P}}$ & 51.8620 & -176.6449 & 5 & Chap-M21/25 & $2012 / 06 / 25$ & $2017 / 06 / 23$ \\
\hline ADKI_01 ${ }^{I}$ & 51.8619 & -176.6439 & 5 & Chap-M21/25 & $2017 / 06 / 23$ & - \\
\hline ADKI_02 ${ }^{I}$ & 51.8632 & -176.6436 & 5 & Chap-M21/25 & $2017 / 06 / 23$ & - \\
\hline ADKI_03 ${ }^{\mathrm{I}}$ & 51.8623 & -176.6446 & 5 & Chap-M21/25 & $2017 / 06 / 23$ & - \\
\hline ADKI_04 & 51.8625 & -176.6458 & 5 & Chap-M21/25 & $2017 / 06 / 23$ & - \\
\hline ADKI_05 $05^{I}$ & 51.8633 & -176.6461 & 5 & Chap-M21/25 & $2017 / 06 / 23$ & - \\
\hline ADKI_06 ${ }^{1}$ & 51.8616 & -176.6469 & 5 & Chap-M21/25 & $2017 / 06 / 23$ & - \\
\hline $\mathrm{AMKA}^{\mathrm{B}}$ & 51.3771 & 179.3000 & 116 & $\mathrm{~T}-40$ & $2005 / 10 / 14$ & - \\
\hline BGM & 59.3920 & -155.2315 & 625 & L-4 & $1978 / 09 / 08$ & - \\
\hline BGR & 60.7569 & -152.4199 & 985 & L-4 & 1991/07/01 & - \\
\hline ETKA & 51.8608 & -176.4079 & 290 & L-4 & $1999 / 09 / 15$ & - \\
\hline MMN & 59.1845 & -154.3389 & 442 & S-13 & $1981 / 08 / 22$ & - \\
\hline $\mathrm{OPT}^{\mathrm{TA}}$ & 59.6526 & -153.2321 & 602 & S-13 & $1974 / 01 / 01$ & - \\
\hline PDB & 59.7841 & -154.1917 & 360 & L-4 & 1978/09/09 & - \\
\hline SDPI_01 ${ }^{I}$ & 55.3490 & -160.4764 & 200 & VDP-10 & $2016 / 10 / 17$ & - \\
\hline SDPI_02I & 55.3487 & -160.4768 & 200 & VDP-10 & $2016 / 10 / 17$ & - \\
\hline SDPI_03 ${ }^{1}$ & 55.3493 & -160.4773 & 200 & VDP-10 & $2016 / 10 / 17$ & - \\
\hline SDPI_04I & 55.3495 & -160.4766 & 200 & VDP-10 & $2016 / 10 / 17$ & - \\
\hline SDPI_05 & 55.3492 & -160.4765 & 200 & VDP-10 & $2016 / 10 / 17$ & - \\
\hline SDPI_06 ${ }^{\mathrm{I}}$ & 55.3492 & -160.4771 & 200 & VDP-10 & $2016 / 10 / 17$ & - \\
\hline STLK & 61.4982 & -151.8349 & 945 & L-4 & $1997 / 09 / 01$ & - \\
\hline STLK $^{3}$ & 61.4982 & -151.8349 & 945 & L-22 & $2016 / 08 / 31$ & $2017 / 08 / 14$ \\
\hline STLK $^{\mathrm{B}}$ & 61.4982 & -151.8349 & 945 & TC120-PH2 & $2017 / 08 / 14$ & - \\
\hline $\mathrm{SYI}^{\mathrm{TA}}$ & 58.6094 & -152.3935 & 149 & L-4 & $1997 / 09 / 01$ & - \\
\hline
\end{tabular}




\section{Appendix 3. Operational Status for Alaska Volcano Observatory Stations in 2013- 17}

The operational status of Alaska Volcano Observatory seismograph stations for 2013-17 is shown using the Incorporated Research Institutions for Seismology (IRIS) Gap/Overlap Analysis Tool (GOAT) (Stromme, 2000). GOAT is a web-based tool which graphically displays gaps, overlaps, and continuous time spans of time series data in the IRIS Data Management Center's database. GOAT cannot determine the quality of the data, just the presence of data on the archived channel.

In figures 3.1-3.7, the plots display a color-coded graph showing gaps in red and continuous data in green. A summary of the station availability is shown in table 3.1. 
Table 3.1. Summary of data availability for Alaska Volcano Observatory (AVO) stations in 2013-17 determined using to the Incorporated Research Institutions for Seismology Gap/Overlap Analysis Tool (Stromme, 2000).

\begin{tabular}{|c|c|}
\hline $\begin{array}{l}\text { Data availability, } \\
\text { in percent }\end{array}$ & AVO seismograph stations sorted by data availability \\
\hline 100 & $\begin{array}{l}\text { ADKI, BPBC, CKL, CKN, CKT, CP2, CRP, ISNN, KAIC, KOFP, KOKL, KOKV, KONE, KNOW, KOSE, KOWE, } \\
\text { MAPS, MREP, MSW, NCG, NCT, OKAK, OKCF, OKER, OKID, OKRE, OKSP, OKTU, OKWE, OKWR, } \\
\text { PV6A, RDT, RSO, SPU, SPWE, STLK, SYI, VNFG, VNHG, WACK. }\end{array}$ \\
\hline $90-99$ & $\begin{array}{l}\text { ADAG, AHB, AKGG, AKMO, AKRB, AKSA, AKS, AU22, AUE, AUH, AUI, AUJA, AUL, AUNW, AUP, AUSB, } \\
\text { AUWS, AUW, BGL, BLDY, BLHA, BRPK, CDD, CGL, CLCO, CLES, CNTC, DFR, DRR3, DT1, DTN, ETKA, } \\
\text { GAEA, GAKI, GALA, GANE, GANO, GASW, GSCK, GSIG, GSMY, GSSP, GSTD, GSTR, HAG, HSB, ILI, } \\
\text { ILSW, ILS, ILW, INE, ISLZ, IVE, KICM, KIKV, KIMD, KINC, KIRH, KIWB, MCIR, MGOD, MNAT, MTBL, } \\
\text { OKCE, OKFG, OPT, PN7A, PS1A, PS4A, PV6, PVV, RDDF, RED, SPBG, SPCG, SSLS, SSLW, TAFL, TAFP, } \\
\text { TANO, TAPA, TASE, VNSG, WEBT, WECS, WESE, WESN, WESP, ZRO. }\end{array}$ \\
\hline $80-89$ & $\begin{array}{l}\text { ACH, AKV, ANCK, AUQ, AUSS, BGM, CAHL, CEAP, CEPE, CERA, CERB, CESW, CETU, FONW, FOPK, } \\
\text { FOSS, ILNE, IVS, KABR, KAHC, KAHG, KAPH, KARR, KAWH, KBM, KCE, KCG ,KEL, KJL, KVT, LSNW, } \\
\text { LSPA, LSSA, LSSE, LVA, MMN, OKSO, PBD, PLBL, PLK1, PLK2, PLK3, PLK4, PLK5, PLWL, RDJH, } \\
\text { RDSO, SPCN, SPCP, SSBA. }\end{array}$ \\
\hline $50-59$ & RDWB, SPNN, WASW. \\
\hline $40-49$ & WTUG. \\
\hline $30-39$ & no stations \\
\hline $20-29$ & no stations \\
\hline $10-19$ & AUJK. \\
\hline $0-9$ & no stations \\
\hline $\begin{array}{l}\text { Unavailable at } \\
\text { IRIS }\end{array}$ & AKT, BGR, BKG, OKIF, RDDR, SDPI, TACS,WANC. \\
\hline
\end{tabular}




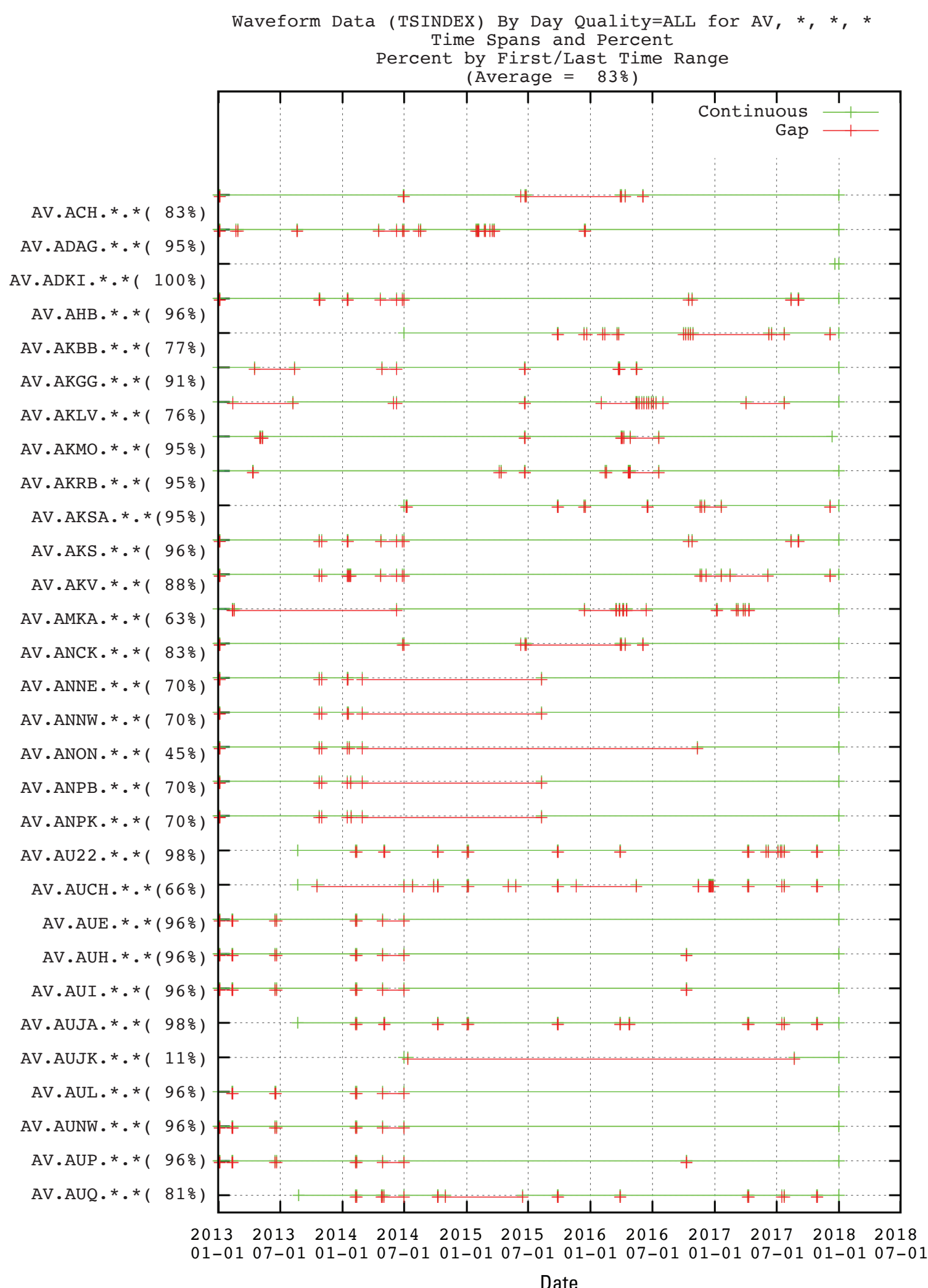

Figure 3.1. Image showing data availability for Alaska Volcano Observatory seismograph stations ACH to AUO determined using the Incorporated Research Institutions for Seismology Gap/Overlap Analysis Tool (Stromme, 2000). Gaps are shown in red, and continuous data is shown in green. \%, percent. Date format is year, two-digit month and day. 


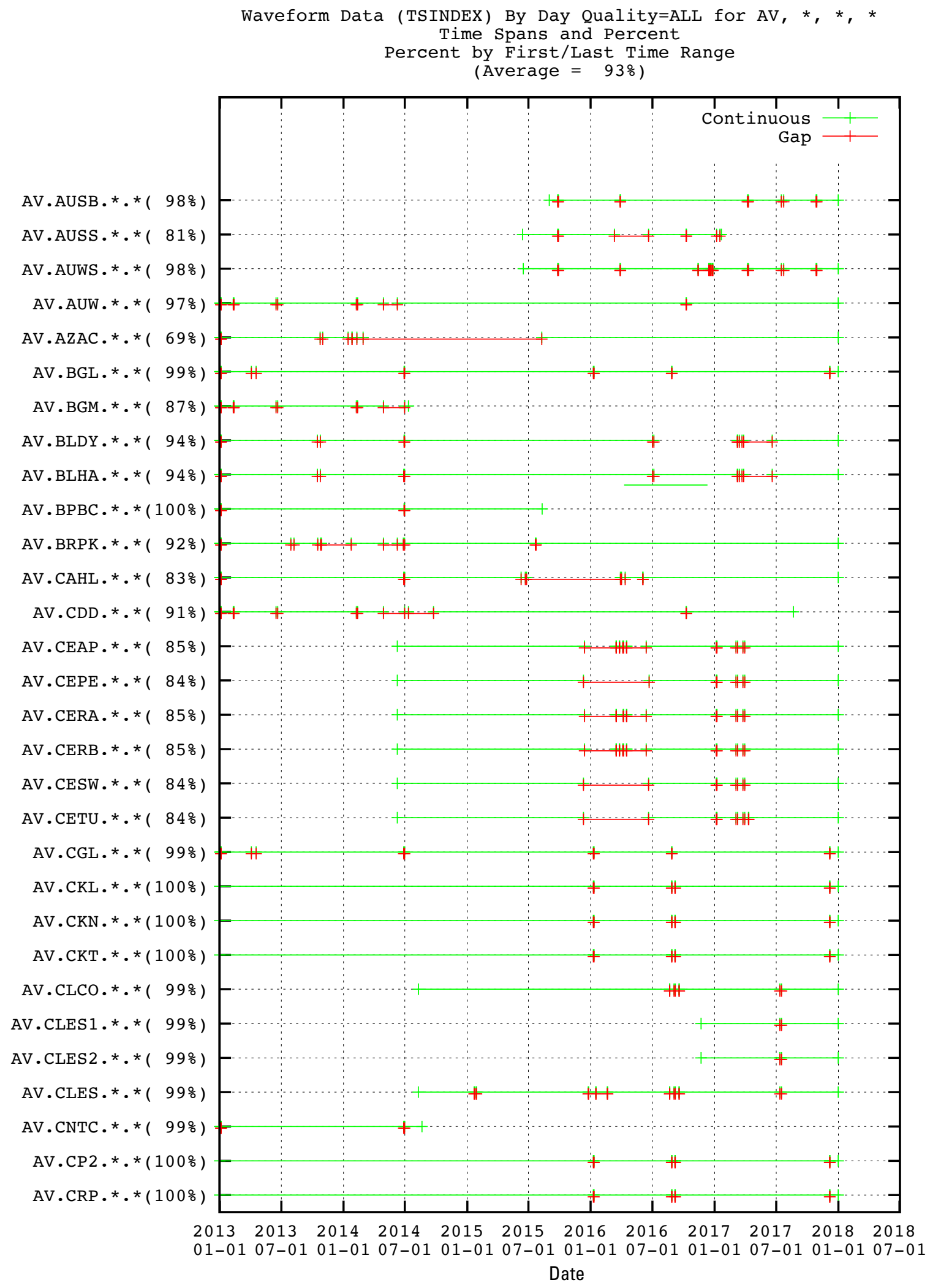

Figure 3.2. Image showing data availability for Alaska Volcano Observatory seismograph stations AUSB to CRP determined using the Incorporated Research Institutions for Seismology Gap/Overlap Analysis Tool (Stromme, 2000). Gaps are shown in red, and continuous data is shown in green. \%, percent. Date/time format is year, two-digit month and day. 
Waveform Data (TSINDEX) By Day Quality=ALL for AV, *, *, *

Time Spans and Percent

Percent by First/Last Time Range

(Average $=92 \%$ )

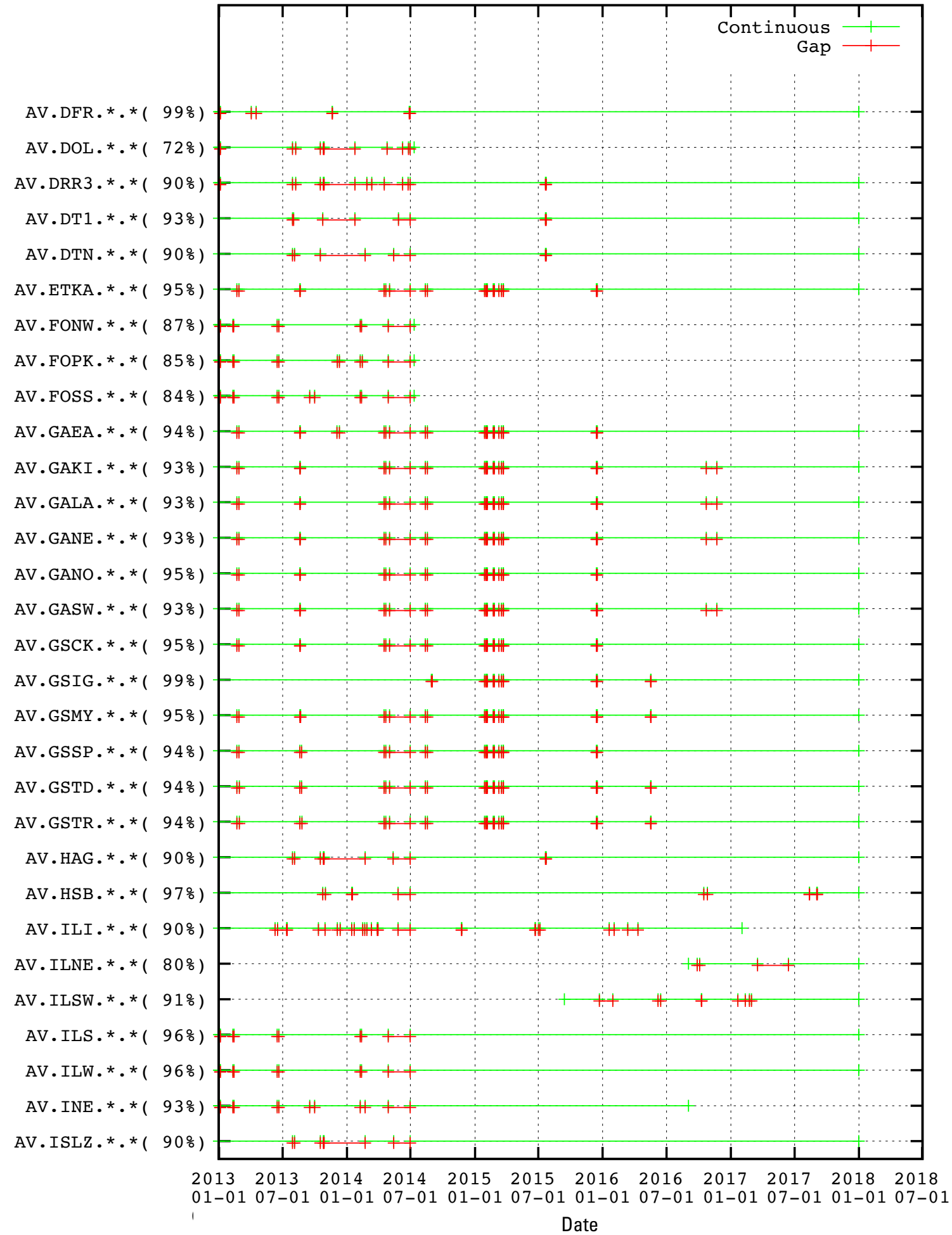

Figure 3.3. Image showing data availability for Alaska Volcano Observatory seismograph stations DFR to ISLZ determined using the Incorporated Research Institutions for Seismology Gap/Overlap Analysis Tool (Stromme, 2000). Gaps are shown in red, and continuous data is shown in green. \%, percent. Date/time format is year, two-digit month and day. 


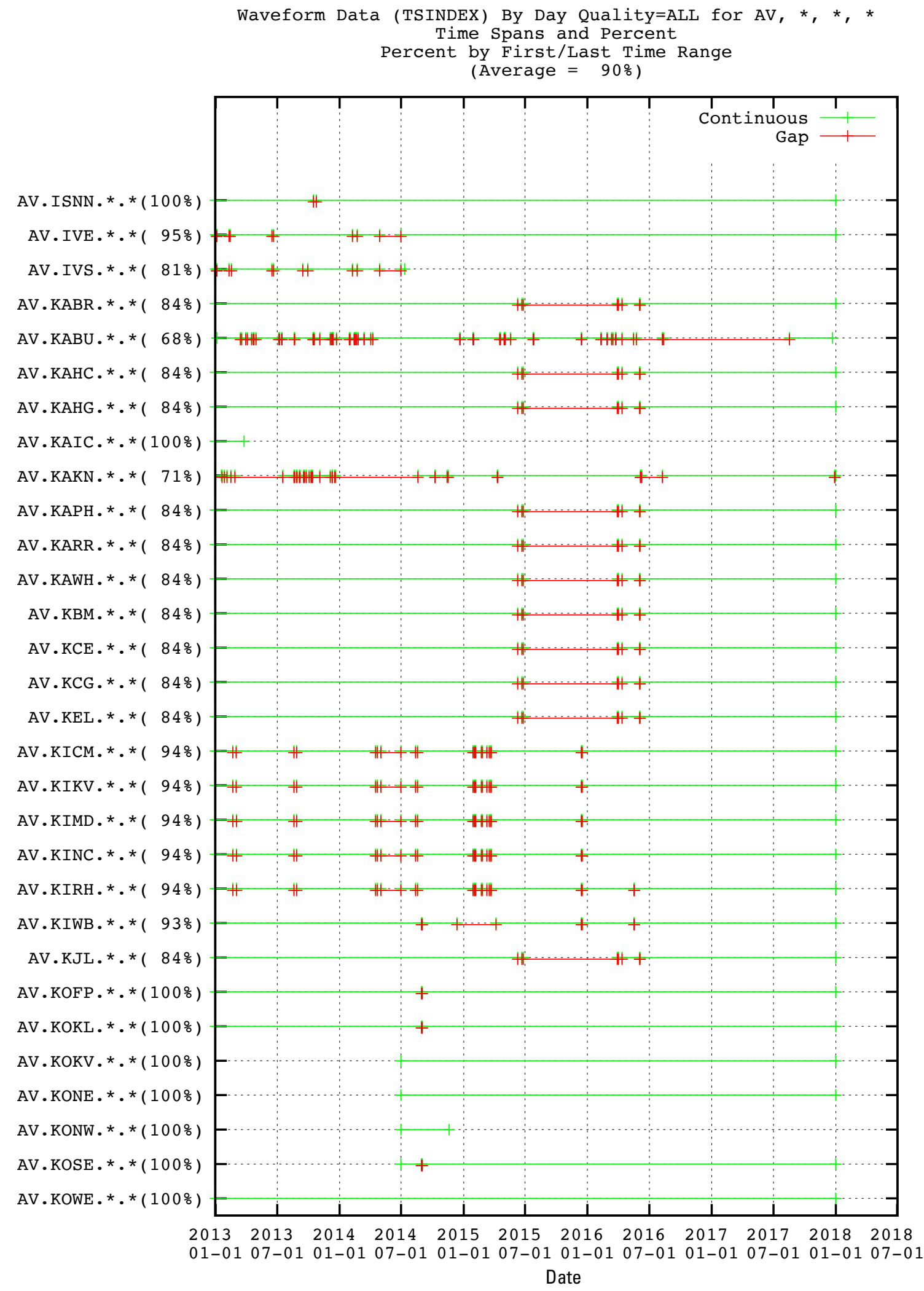

Figure 3.4. Image showing data availability for Alaska Volcano Observatory seismograph stations ISNN to KOWE determined using the Incorporated Research Institutions for Seismology Gap/Overlap Analysis Tool (Stromme, 2000). Gaps are shown in red, and continuous data is shown in green. \%, percent. Date/time format is year, two-digit month and day 
Waveform Data (TSINDEX) By Day Quality=ALL for AV, *, *, * Time Spans and Percent

Percent by First/Last Time Range $($ Average $=91 \%)$

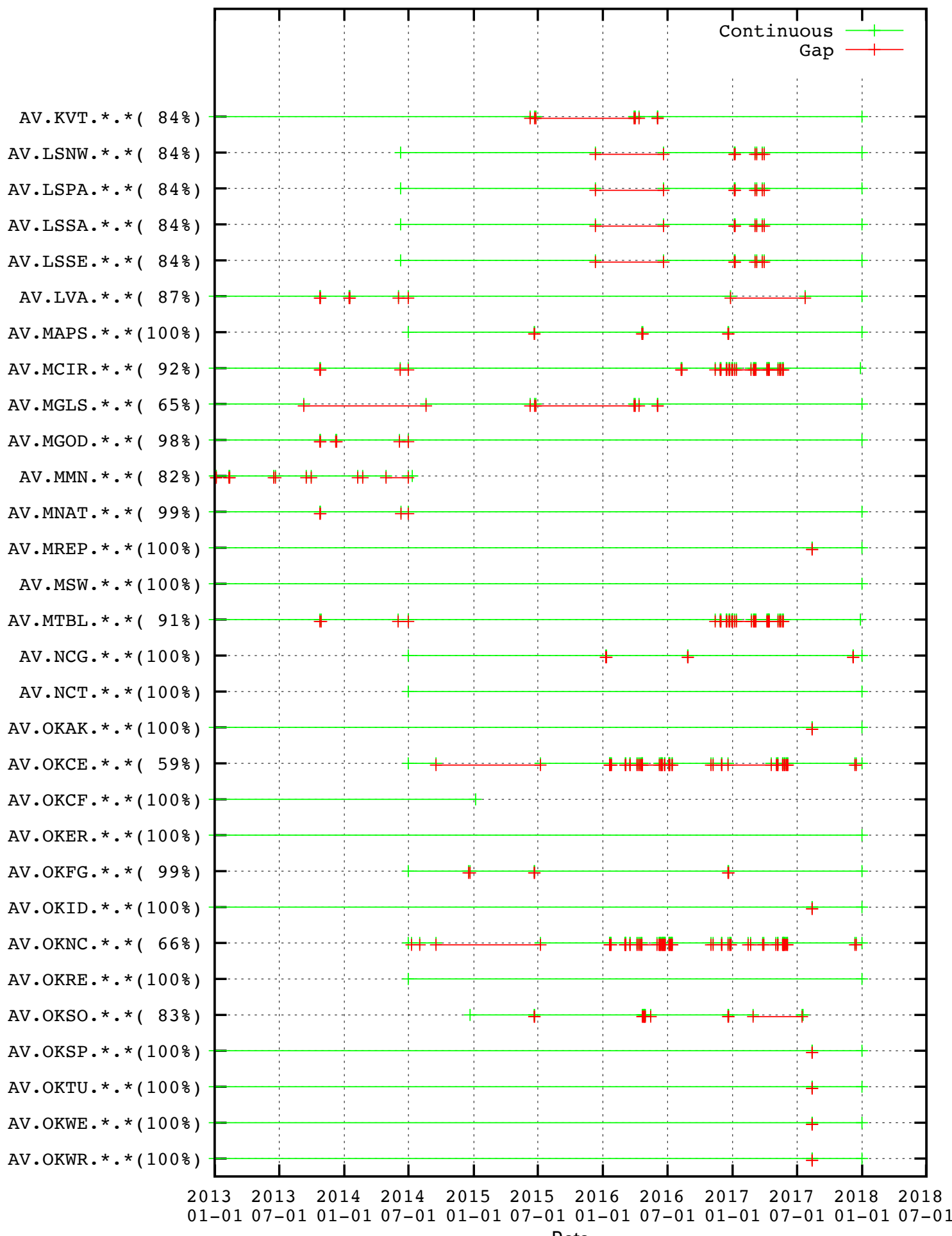

Date

Figure 3.5. Image showing data availability for Alaska Volcano Observatory seismograph stations KVT to OKWR determined using the Incorporated Research Institutions for Seismology Gap/Overlap Analysis Tool (Stromme, 2000). Gaps are shown in red, and continuous data is shown in green. \%, percent. Date/time format is year, two-digit month and day 


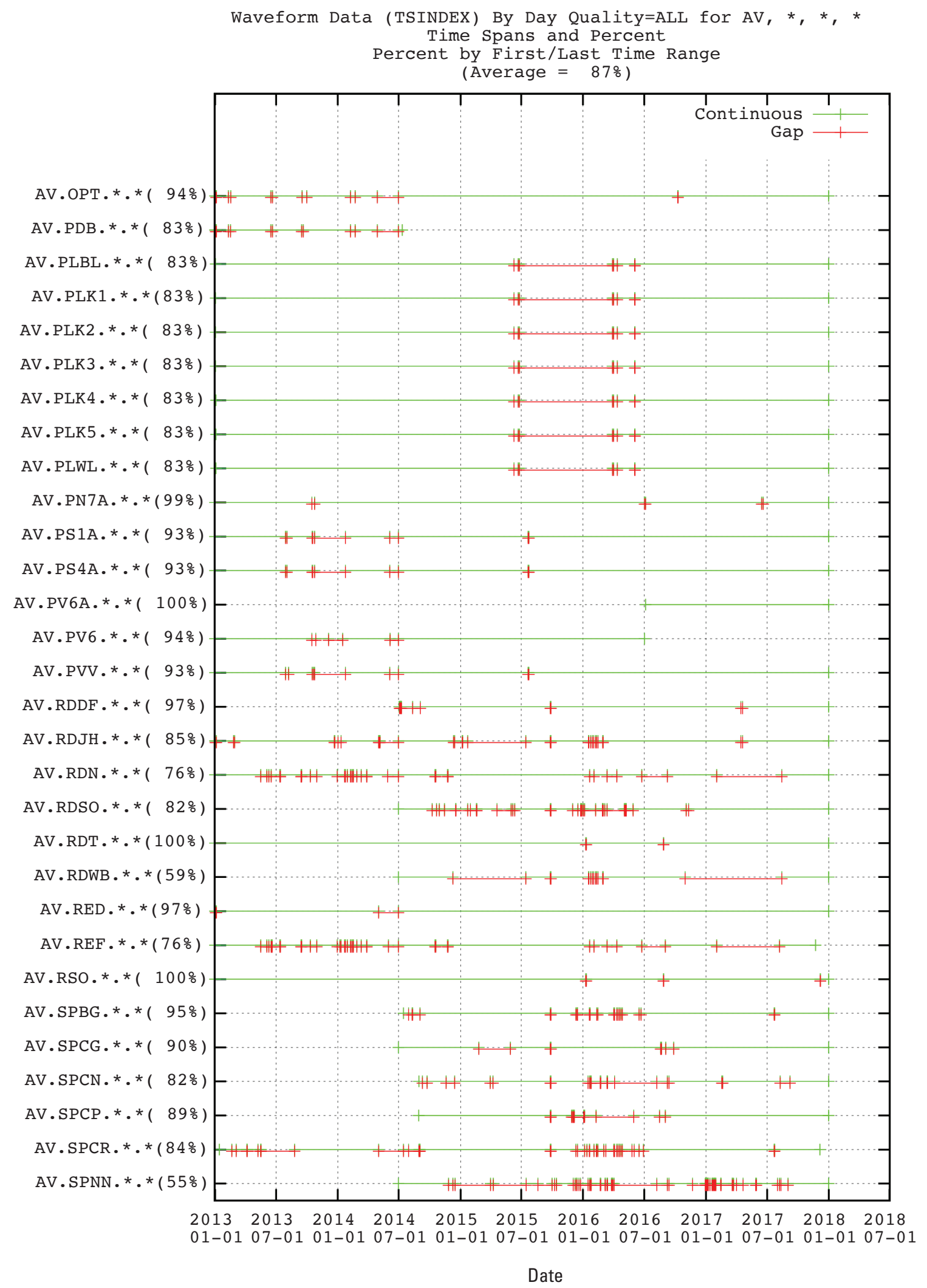

Figure 3.6. Image showing data availability for Alaska Volcano Observatory seismograph stations OPT to SPNN determined using the Incorporated Research Institutions for Seismology Gap/Overlap Analysis Tool (Stromme, 2000). Gaps are shown in red, and continuous data is shown in green. \%, percent. Date/time format is year, two-digit month and day 


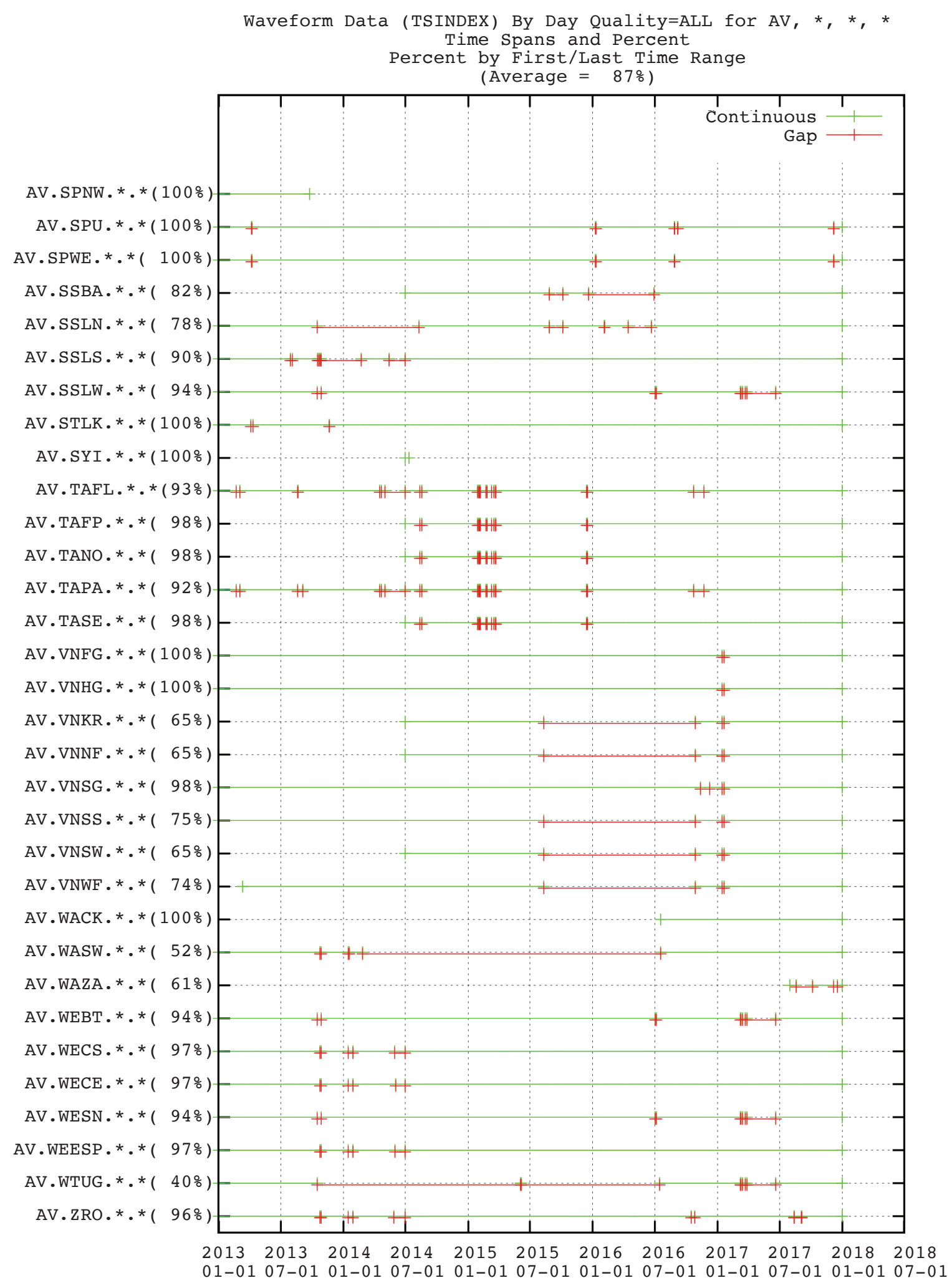

Date

Figure 3.7. Image showing data availability for Alaska Volcano Observatory seismograph stations SPNW to ZRO determined using the Incorporated Research Institutions for Seismology Gap/Overlap Analysis Tool (Stromme, 2000). Gaps are shown in red, and continuous data is shown in green. \%, percent. Date/time format is year, two-digit month and day 
This page left blank intentionally 


\section{Appendix 4. Data Use Scores for Alaska Volcano Observatory Stations in 2013- 17}

Data-use scores developed by Matthew Haney are a normalized measure of the number of P-phases picks on a seismograph station in the Alaska Volcano Observatory (AVO) earthquake catalog. They represent a combination of data availability, data quality, and picking preference of the analyst in the case of co-located instruments at a site. The normalization seeks to remove, as much as possible, the effect of frequency of earthquake occurrence near a particular station.

The scores given in the tables 4.1-4.26 are based on an empirical relation derived from the AVO catalog between local magnitude $\left(M_{1}\right)$ and the distance to the farthest P-phase pick (dmax):

$$
M_{L}=0.8494 \times \log 10(d \text { max })+0.0036 d \text { max }-0.7112
$$

The relationship quantifies the fact that larger earthquakes register on stations at farther distances and in general are picked to greater range from the epicenter. For example, the above relation predicts that an earthquake with a magnitude of approximately 1.5 should be picked to distances of about $100 \mathrm{~km}$. The regression model consists of three coefficients in the above equation which can be related to average values of geometrical spreading, attenuation, and site conditions in the Aleutian arc.

Given the above relation between $M_{\perp}$ and $d \max$, whether a station should have been picked or not can be established for a located earthquake in the AVO catalog with a certain magnitude. Thus, the number of times a station should have been picked for the earthquakes in the AVO catalog can be determined, and this quantity can be compared to the number of times the station was actually picked. The ratio of the actual number of P-phase picks to the predicted number multiplied by 100 is the data use score. A score of 100 means a station was picked the same number of times it should have been picked based on the $M_{\mathrm{L}}$-dmax relation. Stations that are picked more often than they should be have data-use scores higher than 100, whereas stations picked less often than they should be have scores below 100 . 
Table 4.1. Data-use scores by year for Alaska Volcano Observatory seismograph stations in the Akutan Peak subnetwork, 2013-17. [NA, not applicable]

\begin{tabular}{lccccc}
\hline \multicolumn{1}{c}{ Station } & $\mathbf{2 0 1 3}$ & $\mathbf{2 0 1 4}$ & $\mathbf{2 0 1 5}$ & $\mathbf{2 0 1 6}$ & $\mathbf{2 0 1 7}$ \\
\hline AHB.EHZ & 83 & 67 & 53 & 73 & 88 \\
AKBB.BHZ & 98 & 115 & 97 & 84 & 37 \\
AKGG.BHZ & 64 & 125 & 89 & 75 & 114 \\
AKLV.BHZ & 55 & 106 & 89 & 69 & 70 \\
AKMO.BHZ & 87 & 110 & 85 & 80 & 73 \\
AKRB.BHZ & 81 & 109 & 98 & 91 & 124 \\
AKS.EHZ & 83 & 96 & 71 & 72 & 79 \\
AKSA.BHZ & 26 & 67 & 46 & 44 & 0 \\
AKT.BHZ & 0 & 0 & 0 & 0 & 11 \\
AKV.BHZ & NA & NA & NA & 0 & NA \\
AKV.EHZ & 65 & 100 & 61 & 42 & 87 \\
HSB.EHZ & 37 & 63 & 29 & 32 & 36 \\
LVA.BHZ & NA & NA & NA & 0 & NA \\
LVA.EHZ & 34 & 38 & 45 & 52 & 143 \\
ZRO.EHZ & 92 & 125 & 105 & 120 & \\
\hline
\end{tabular}

Table 4.2. Data-use scores by year for Alaska Volcano Observatory seismograph stations in the Aniakchak Crater subnetwork, 2013-17.

\begin{tabular}{lccccc}
\hline Station & $\mathbf{2 0 1 3}$ & $\mathbf{2 0 1 4}$ & $\mathbf{2 0 1 5}$ & $\mathbf{2 0 1 6}$ & $\mathbf{2 0 1 7}$ \\
\hline ANNE.EHZ & 118 & 0 & 15 & 77 & 86 \\
ANNW.EHZ & 68 & 0 & 10 & 89 & 63 \\
ANON.EHZ & 0 & 0 & 0 & 6 & 46 \\
ANPB.EHZ & 161 & 0 & 14 & 95 & 96 \\
ANPK.EHZ & 45 & 0 & 0 & 0 & 45 \\
AZAC.EHZ & 118 & 0 & 8 & 84 & 80 \\
\hline
\end{tabular}


Table 4.3. Data-use scores by year for Alaska Volcano Observatory seismograph stations in the Augustine Volcano subnetwork, 2013-17.

[NA, not applicable]

\begin{tabular}{lccccc}
\hline \multicolumn{1}{c}{ Station } & $\mathbf{2 0 1 3}$ & $\mathbf{2 0 1 4}$ & $\mathbf{2 0 1 5}$ & $\mathbf{2 0 1 6}$ & $\mathbf{2 0 1 7}$ \\
\hline AU22.BHZ & 9 & 18 & 48 & 12 & 5 \\
AUCH.BHZ & NA & 27 & 79 & 74 & 106 \\
AUE.EHZ & 28 & 29 & 33 & 10 & 3 \\
AUH.EHZ & 70 & 85 & 86 & 109 & 86 \\
AUI.EHZ & 32 & 0 & 0 & 0 & 0 \\
AUJA.BHZ & 0 & 57 & 91 & 156 & 146 \\
AUJK.EHZ & 99 & 44 & 0 & 0 & 26 \\
AUL.BHZ & 85 & 63 & 99 & 168 & 161 \\
AUL.EHZ & 2 & 4 & 0 & 0 & 0 \\
AUNW.EHZ & 0 & 0 & 0 & 0 & 0 \\
AUP.EHZ & 66 & 77 & 57 & 0 & 0 \\
AUQ.BHZ & 12 & 48 & 00 & 0 & 137 \\
AUSB.BHZ & NA & NA & 70 & 36 \\
AUSS.BHZ & NA & 86 & 76 & 22 & 1 \\
AUW.EHZ & 103 & NA & 12 & 145 & 27 \\
AUW.B.BHZ & NA & & & & 126 \\
\hline
\end{tabular}

Table 4.4. Data-use scores by year for Alaska Volcano Observatory seismograph stations in the Mount Cerberus subnetwork, 2013-17. [NA, not applicable]

\begin{tabular}{lccccc}
\hline \multicolumn{1}{r}{ Station } & $\mathbf{2 0 1 3}$ & $\mathbf{2 0 1 4}$ & $\mathbf{2 0 1 5}$ & $\mathbf{2 0 1 6}$ & $\mathbf{2 0 1 7}$ \\
\hline CEAP.SHZ & 2 & 121 & 135 & 43 & 28 \\
CEPE.SHZ & 0 & 0 & 6 & 59 & 47 \\
CERA.SHZ & 1 & 114 & 145 & 52 & 25 \\
CERB.SHZ & 1 & 103 & 113 & 38 & 21 \\
CESW.SHZ & 1 & 116 & 123 & 54 & 40 \\
CETU.SHZ & 2 & 84 & 31 & 36 & 28 \\
\hline
\end{tabular}


Table 4.5. Data-use scores by year for Alaska Volcano Observatory seismograph stations in the Mount Cleveland subnetwork, 2013-17.

[NA, not applicable]

\begin{tabular}{lccccc}
\hline Station & $\mathbf{2 0 1 3}$ & $\mathbf{2 0 1 4}$ & $\mathbf{2 0 1 5}$ & $\mathbf{2 0 1 6}$ & $\mathbf{2 0 1 7}$ \\
\hline CLCO.BHZ & NA & 26 & 76 & 67 & 51 \\
CLCO.SHZ & NA & 0 & 5 & 3 & 0 \\
CLES.BHZ & NA & 26 & 77 & 67 & 50 \\
CLES.SHZ & NA & 0 & 0 & 4 & 3 \\
\hline
\end{tabular}

Table 4.6. Data-use scores by year for Alaska Volcano Observatory seismograph stations in the Mount Dutton subnetwork, $2013-17$. [NA, not applicable]

\begin{tabular}{lccccc}
\hline \multicolumn{1}{r}{ Station } & $\mathbf{2 0 1 3}$ & $\mathbf{2 0 1 4}$ & $\mathbf{2 0 1 5}$ & $\mathbf{2 0 1 6}$ & $\mathbf{2 0 1 7}$ \\
\hline BLDY.EHZ & 0 & 11 & 18 & 9 & 0 \\
DOL.EHZ & 68 & 35 & 0 & 0 & 0 \\
DRR3.EHZ & 60 & 3 & 0 & 0 & 0 \\
DT1.EHZ & 47 & 63 & 49 & 40 & 17 \\
DTN.EHZ & 34 & 0 & 0 & 32 & 12 \\
\hline
\end{tabular}

Table 4.7. Data-use scores by year for Alaska Volcano Observatory seismograph stations in the Fourpeaked Mountain subnetwork, 2013-17.

\begin{tabular}{lccccc}
\hline \multicolumn{1}{c}{ Station } & $\mathbf{2 0 1 3}$ & $\mathbf{2 0 1 4}$ & $\mathbf{2 0 1 5}$ & $\mathbf{2 0 1 6}$ & $\mathbf{2 0 1 7}$ \\
\hline CDD.EHZ & 0 & 0 & 0 & 0 & 0 \\
FONW.EHZ & 77 & 0 & 0 & 0 & 0 \\
FOPK.EHZ & 0 & 0 & 0 & 0 & 0 \\
FOSS.EHZ & 16 & 3 & 0 & 0 & 0 \\
\hline
\end{tabular}

Table 4.8. Data-use scores by year for Alaska Volcano Observatory seismograph stations in the Mount Gareloi subnetwork, 2013-17.

\begin{tabular}{lccccc}
\hline Station & $\mathbf{2 0 1 3}$ & $\mathbf{2 0 1 4}$ & $\mathbf{2 0 1 5}$ & $\mathbf{2 0 1 6}$ & $\mathbf{2 0 1 7}$ \\
\hline GAEA.EHZ & 63 & 58 & 65 & 105 & 81 \\
GAKI.EHZ & 0 & 0 & 6 & 31 & 4 \\
GALA.EHZ & 30 & 28 & 57 & 103 & 46 \\
GANE.EHZ & 2 & 0 & 24 & 44 & 43 \\
GANO.EHZ & 0 & 0 & 36 & 96 & 71 \\
GASW.EHZ & 0 & 0 & 30 & 86 & 26 \\
\hline
\end{tabular}


Table 4.9. Data-use scores by year for Alaska Volcano Observatory seismograph stations in the Great Sitkin Volcano subnetwork, 2013-17.

\begin{tabular}{lccccc}
\hline \multicolumn{1}{r}{ Station } & $\mathbf{2 0 1 3}$ & $\mathbf{2 0 1 4}$ & $\mathbf{2 0 1 5}$ & $\mathbf{2 0 1 6}$ & $\mathbf{2 0 1 7}$ \\
\hline GSCK.EHZ & 12 & 11 & 48 & 197 & 219 \\
GSIG.EHZ & 0 & 0 & 64 & 42 & 0 \\
GSMY.EHZ & 159 & 127 & 148 & 145 & 219 \\
GSSP.EHZ & 83 & 34 & 75 & 136 & 163 \\
GSTD.EHZ & 96 & 88 & 113 & 154 & 87 \\
GSTR.EHZ & 111 & 73 & 97 & 175 & 202 \\
\hline
\end{tabular}

Table 4.10. Data-use scores by year for Alaska Volcano Observatory seismograph stations in the lliamna Volcano subnetwork, 2013-17.

[NA, not applicable]

\begin{tabular}{lccccc}
\hline \multicolumn{1}{c}{ Station } & $\mathbf{2 0 1 3}$ & $\mathbf{2 0 1 4}$ & $\mathbf{2 0 1 5}$ & $\mathbf{2 0 1 6}$ & $\mathbf{2 0 1 7}$ \\
\hline ILI.EHZ & 33 & 23 & 9 & 5 & 0 \\
ILNE.SHZ & NA & NA & NA & 0 & 38 \\
ILS.BHZ & NA & NA & 0 & 0 & 23 \\
ILS.EHZ & 216 & 84 & 57 & 0 & 0 \\
ILSW.BHZ & NA & NA & 0 & 0 & 44 \\
ILW.BHZ & 14 & 0 & 0 & 0 & NA \\
ILW.EHZ & 330 & 51 & 2 & 0 & 0 \\
ILW.SHZ & NA & NA & NA & 0 & 25 \\
INE.EHZ & 237 & 13 & 9 & 0 & 0 \\
IVE.BHZ & 10 & 15 & 75 & 9 & 49 \\
IVE.EHZ & 234 & 61 & 9 & 0 & 0 \\
IVS.EHZ & 0 & 0 & 0 & 0 & 0 \\
\hline
\end{tabular}

Table 4.11. Data-use scores by year for Alaska Volcano Observatory seismograph stations in the Kanaga Volcano subnetwork, 2013-17.

\begin{tabular}{lccccc}
\hline \multicolumn{1}{r}{ Station } & $\mathbf{2 0 1 3}$ & $\mathbf{2 0 1 4}$ & $\mathbf{2 0 1 5}$ & $\mathbf{2 0 1 6}$ & $\mathbf{2 0 1 7}$ \\
\hline KICM.EHZ & 92 & 90 & 83 & 95 & 53 \\
KIKV.EHZ & 118 & 109 & 103 & 136 & 71 \\
KIMD.EHZ & 96 & 95 & 105 & 128 & 139 \\
KINC.EHZ & 88 & 83 & 57 & 96 & 42 \\
KIRH.EHZ & 116 & 96 & 79 & 56 & 14 \\
KIWB.EHZ & 89 & 13 & 72 & 115 & 66 \\
\hline
\end{tabular}


Table 4.12. Data-use scores by year for Alaska Volcano Observatory seismograph stations in the Katmai volcanic cluster subnetwork, 2013-17.

[NA, not applicable]

\begin{tabular}{lccccc}
\hline \multicolumn{1}{c}{ Station } & $\mathbf{2 0 1 3}$ & $\mathbf{2 0 1 4}$ & $\mathbf{2 0 1 5}$ & $\mathbf{2 0 1 6}$ & $\mathbf{2 0 1 7}$ \\
\hline ACH.BHZ & NA & NA & NA & NA & 35 \\
ACH.EHZ & 77 & 66 & 99 & 25 & 0 \\
ANCK.BHZ & NA & NA & NA & 0 & 27 \\
ANCK.EHZ & 60 & 92 & 94 & 29 & NA \\
CAHL.EHZ & 99 & 96 & 111 & 35 & 0 \\
CNTC.EHZ & 15 & 0 & 0 & 0 & 0 \\
KABR.EHZ & 64 & 53 & 112 & 48 & 70 \\
KABU.BHZ & 71 & 106 & 125 & 10 & 63 \\
KAHC.EHZ & 127 & 147 & 156 & 71 & 107 \\
KAHG.BHZ & NA & NA & NA & NA & 33 \\
KAHG.EHZ & 78 & 65 & 70 & 46 & 30 \\
KAIC.EHZ & 0 & 0 & 0 & 0 & 0 \\
KAKN.BHZ & 54 & 78 & 58 & 77 & 470 \\
KAPH.EHZ & 33 & 53 & 60 & 49 & 49 \\
KARR.EHZ & 77 & 54 & 64 & 45 & 44 \\
KAWH.EHZ & 49 & 61 & 49 & 45 & 127 \\
KBM.EHZ & 71 & 86 & 159 & 64 & 127 \\
KCE.EHZ & 72 & 75 & 139 & 55 & 168 \\
KCG.EHZ & 71 & 128 & 100 & 100 & 49 \\
KEL.EHZ & 86 & 57 & 66 & 46 & 0 \\
KJL.EHZ & 59 & 50 & 54 & 18 & 20 \\
KVT.EHZ & 62 & 95 & 197 & & 0 \\
MGLS.EHZ & 12 & 20 & 50 & & \\
\hline
\end{tabular}

Table 4.13. Data-use scores by year for Alaska Volcano Observatory seismograph stations in the Korovin Volcano subnetwork, 2013-17.

\begin{tabular}{lccccc}
\hline \multicolumn{1}{r}{ Station } & $\mathbf{2 0 1 3}$ & $\mathbf{2 0 1 4}$ & $\mathbf{2 0 1 5}$ & $\mathbf{2 0 1 6}$ & $\mathbf{2 0 1 7}$ \\
\hline KOFP.EHZ & 104 & 165 & 159 & 130 & 80 \\
KOKL.EHZ & 96 & 128 & 114 & 104 & 70 \\
KOKV.EHZ & 15 & 4 & 0 & 1 & 8 \\
KONE.EHZ & 28 & 79 & 64 & 47 & 38 \\
KONW.EHZ & 51 & 14 & 0 & 0 & 0 \\
KOSE.EHZ & 46 & 142 & 114 & 91 & 74 \\
KOWE.EHZ & 94 & 141 & 107 & 101 & 65 \\
\hline
\end{tabular}


Table 4.14. Data-use scores by year for Alaska Volcano Observatory seismograph stations in the Little Sitkin Volcano subnetwork, 2013-17.

\begin{tabular}{lccccc}
\hline \multicolumn{1}{c}{ Station } & $\mathbf{2 0 1 3}$ & $\mathbf{2 0 1 4}$ & $\mathbf{2 0 1 5}$ & $\mathbf{2 0 1 6}$ & $\mathbf{2 0 1 7}$ \\
\hline LSNW.SHZ & 13 & 64 & 95 & 72 & 23 \\
LSPA.SHZ & 9 & 64 & 96 & 73 & 25 \\
LSSA.SHZ & 13 & 49 & 85 & 63 & 23 \\
LSSE.SHZ & 9 & 51 & 94 & 76 & 26 \\
\hline
\end{tabular}

Table 4.15. Data-use scores by year for Alaska Volcano Observatory seismograph stations in the Makushin Volcano subnetwork, 2013-17.

[NA, not applicable]

\begin{tabular}{|c|c|c|c|c|c|}
\hline Station & 2013 & 2014 & 2015 & 2016 & 2017 \\
\hline MAPS.BHZ & 119 & 175 & 186 & 192 & 280 \\
\hline MCIR.BHZ & NA & NA & NA & 0 & 132 \\
\hline MCIR.EHZ & 104 & 98 & 78 & 23 & NA \\
\hline MGOD.BHZ & 124 & 107 & 134 & 108 & 290 \\
\hline MGOD.EHZ & 29 & 28 & 36 & 68 & 2 \\
\hline MNAT.BHZ & 157 & 206 & 225 & 117 & 262 \\
\hline MNAT.EHZ & 5 & 0 & 1 & 63 & 1 \\
\hline MREP.EHZ & 161 & 200 & 173 & 124 & 183 \\
\hline MSW.BHZ & 150 & 215 & 232 & 182 & 298 \\
\hline MSW.EHZ & 32 & 9 & 11 & 32 & NA \\
\hline MTBL.BHZ & NA & NA & NA & 0 & 16 \\
\hline MTBL.EHZ & 141 & 144 & 197 & 127 & NA \\
\hline
\end{tabular}

Table 4.16. Data-use scores by year for Alaska Volcano Observatory seismograph stations in the Okmok Caldera subnetwork, $2013-17$.

\begin{tabular}{lccccc}
\hline Station & $\mathbf{2 0 1 3}$ & $\mathbf{2 0 1 4}$ & $\mathbf{2 0 1 5}$ & $\mathbf{2 0 1 6}$ & $\mathbf{2 0 1 7}$ \\
\hline OKAK.EHZ & 97 & 107 & 100 & 59 & 25 \\
OKCE.BHZ & 9 & 52 & 16 & 13 & 19 \\
OKCF.EHZ & 0 & 1 & 0 & 0 & 0 \\
OKER.EHZ & 25 & 20 & 41 & 43 & 49 \\
OKFG.BHZ & 49 & 67 & 63 & 56 & 111 \\
OKID.EHZ & 0 & 0 & 10 & 15 & 0 \\
OKNC.BHZ & 37 & 32 & 93 & 38 & 80 \\
OKRE.EHZ & 29 & 41 & 75 & 48 & 22 \\
OKSO.BHZ & 0 & 2 & 84 & 78 & 5 \\
OKSP.EHZ & 95 & 96 & 99 & 51 & 31 \\
OKTU.EHZ & 86 & 109 & 67 & 42 & 45 \\
OKWE.EHZ & 98 & 113 & 16 & 24 & 39 \\
OKWR.EHZ & 63 & 76 & & \\
\hline
\end{tabular}




\section{Catalog of Earthquake Parameters and Description of Seismograph and Infrasound Stations at Alaskan Volcanoes}

Table 4.17. Data-use scores by year for Alaska Volcano Observatory seismograph stations in the Pavlof Volcano subnetwork, 2013-17.

[NA, not applicable]

\begin{tabular}{lccccc}
\hline \multicolumn{1}{r}{ Station } & $\mathbf{2 0 1 3}$ & $\mathbf{2 0 1 4}$ & $\mathbf{2 0 1 5}$ & $\mathbf{2 0 1 6}$ & $\mathbf{2 0 1 7}$ \\
\hline BLHA.EHZ & 0 & 27 & 23 & 16 & 0 \\
HAG.EHZ & 43 & 62 & 49 & 49 & 39 \\
HAG.SHZ & NA & NA & NA & NA & 13 \\
PN7A.BHZ & NA & NA & NA & NA & 14 \\
PN7A.EHZ & 26 & 44 & 45 & 6 & NA \\
PN7A.SHZ & NA & NA & NA & 0 & 25 \\
PS1A.BHZ & NA & NA & NA & NA & 19 \\
PS1A.EHZ & 29 & 53 & 28 & 33 & 21 \\
PS4A.BHZ & NA & NA & NA & NA & 14 \\
PS4A.EHZ & 91 & 83 & 59 & 42 & 43 \\
PV6.EHZ & 26 & 42 & 41 & 0 & NA \\
PV6A.SHZ & NA & NA & NA & 0 & 49 \\
PVV.EHZ & 41 & 64 & 41 & 34 & 36 \\
PVV.SHZ & NA & NA & NA & NA & 15 \\
\hline
\end{tabular}

Table 4.18. Data-use scores by year for Alaska Volcano Observatory seismograph stations in the Redoubt Volcano subnetwork, 2013-17.

[NA, not applicable]

\begin{tabular}{lccccc}
\hline \multicolumn{1}{c}{ Station } & $\mathbf{2 0 1 3}$ & $\mathbf{2 0 1 4}$ & $\mathbf{2 0 1 5}$ & $\mathbf{2 0 1 6}$ & $\mathbf{2 0 1 7}$ \\
\hline DFR.EHZ & 170 & 22 & 168 & 213 & 217 \\
NCT.BHZ & 43 & 43 & 191 & 227 & 215 \\
NCT.EHZ & 139 & 10 & 12 & 7 & 9 \\
RDDF.BHZ & 45 & 126 & 189 & 234 & 191 \\
RDDR.EHZ & 0 & 0 & 0 & 0 & 0 \\
RDJH.BHZ & 124 & 93 & 48 & 174 & 127 \\
RDN.EHZ & 76 & 56 & 80 & 13 & 69 \\
RDSO.BHZ & 147 & 67 & 131 & 115 & 218 \\
RDT.BHZ & $\mathrm{NA}$ & $\mathrm{NA}$ & $\mathrm{NA}$ & $\mathrm{NA}$ & 33 \\
RDT.EHZ & 145 & 171 & 163 & 182 & 140 \\
RDWB.BHZ & 211 & 132 & 101 & 173 & 94 \\
RED.BHZ & 186 & 123 & 199 & 152 & 226 \\
RED.EHZ & 3 & 6 & $\mathrm{NA}$ & $\mathrm{NA}$ & $\mathrm{NA}$ \\
REF.EHZ & 79 & 31 & 120 & 23 & 0 \\
REF.SHZ & 0 & 0 & 0 & 0 & 13 \\
RSO.EHZ & 175 & 122 & 193 & 140 & 192 \\
\hline
\end{tabular}


Table 4.19. Data-use scores by year for Alaska Volcano Observatory seismograph stations in the Shishaldin Volcano subnetwork, 2013-17.

[NA, not applicable]

\begin{tabular}{lccccc}
\hline \multicolumn{1}{r}{ Station } & $\mathbf{2 0 1 3}$ & $\mathbf{2 0 1 4}$ & $\mathbf{2 0 1 5}$ & $\mathbf{2 0 1 6}$ & $\mathbf{2 0 1 7}$ \\
\hline BRPK.EHZ & 0 & 44 & 66 & 54 & 42 \\
ISLZ.BHZ & NA & NA & 61 & 64 & 37 \\
ISLZ.EHZ & 25 & 10 & 0 & 0 & 11 \\
ISNN.EHZ & 0 & 0 & 45 & 51 & 33 \\
ISNN.SHZ & NA & NA & NA & 0 & 10 \\
SSBA.BHZ & 34 & 73 & 68 & 44 & 50 \\
SSLN.BHZ & NA & 27 & 40 & 41 & 41 \\
SSLN.EHZ & 12 & 20 & 17 & 19 & 16 \\
SSLS.BHZ & NA & 27 & 56 & 45 & 32 \\
SSLS.EHZ & 16 & 5 & 0 & 0 & 0 \\
SSLW.EHZ & 28 & 50 & 55 & 50 & 26 \\
\hline
\end{tabular}

Table 4.20. Data-use scores by year for Alaska Volcano Observatory seismograph stations in the Mount Spurr subnetwork, 2013-17.

[NA, not applicable]

\begin{tabular}{lccccc}
\hline \multicolumn{1}{c}{ Station } & $\mathbf{2 0 1 3}$ & $\mathbf{2 0 1 4}$ & $\mathbf{2 0 1 5}$ & $\mathbf{2 0 1 6}$ & $\mathbf{2 0 1 7}$ \\
\hline BGL.EHZ & 275 & 107 & 208 & 182 & 202 \\
CGL.EHZ & 319 & 178 & 242 & 193 & 182 \\
CKL.EHZ & 259 & 125 & 195 & 270 & 156 \\
CKN.EHZ & 203 & 139 & 182 & 120 & 161 \\
CKT.EHZ & 199 & 132 & 161 & 122 & 126 \\
CP2.EHZ & 64 & 58 & 102 & 13 & 46 \\
CRP.EHZ & 195 & 113 & 198 & 176 & 169 \\
NCG.EHZ & 80 & 0 & 0 & 0 & 0 \\
SPBG.BHZ & 99 & 102 & 154 & 149 & 117 \\
SPCG.BHZ & 168 & 194 & 261 & 369 & 234 \\
SPCN.BHZ & 27 & 47 & 187 & 37 & 107 \\
SPCP.BHZ & 119 & 95 & 208 & 107 & 209 \\
SPCR.BHZ & 87 & 110 & 174 & 136 & 128 \\
SPNN.BHZ & 156 & 112 & 60 & 14 & 82 \\
SPU.BHZ & NA & NA & NA & NA & 0 \\
SPU.EHZ & 108 & 51 & 186 & 269 & 203 \\
SPWE.EHZ & 258 & 111 & 199 & 117 & 0 \\
\hline
\end{tabular}




\section{Catalog of Earthquake Parameters and Description of Seismograph and Infrasound Stations at Alaskan Volcanoes}

Table 4.21. Data-use scores by year for Alaska Volcano Observatory seismograph stations in the Tanaga Volcano subnetwork, 2013-17.

\begin{tabular}{lccccc}
\hline \multicolumn{1}{r}{ Station } & $\mathbf{2 0 1 3}$ & $\mathbf{2 0 1 4}$ & $\mathbf{2 0 1 5}$ & $\mathbf{2 0 1 6}$ & $\mathbf{2 0 1 7}$ \\
\hline TACS.EHZ & 0 & 0 & 0 & 0 & 0 \\
TAFL.EHZ & 21 & 0 & 29 & 76 & 64 \\
TAFP.EHZ & 103 & 100 & 101 & 107 & 91 \\
TANO.EHZ & 65 & 74 & 66 & 63 & 37 \\
TAPA.EHZ & 81 & 85 & 67 & 91 & 67 \\
TASE.EHZ & 98 & 96 & 105 & 108 & 61 \\
\hline
\end{tabular}

Table 4.22. Data-use scores by year for Alaska Volcano Observatory seismograph stations in the Ugahik-Peulik Volcano subnetwork, 2013-17.

\begin{tabular}{lccccc}
\hline \multicolumn{1}{r}{ Station } & $\mathbf{2 0 1 3}$ & $\mathbf{2 0 1 4}$ & $\mathbf{2 0 1 5}$ & $\mathbf{2 0 1 6}$ & $\mathbf{2 0 1 7}$ \\
\hline PLBL.EHZ & 36 & 39 & 55 & 18 & 21 \\
PLK1.EHZ & 78 & 74 & 80 & 23 & 39 \\
PLK2.EHZ & 52 & 56 & 57 & 5 & 0 \\
PLK3.EHZ & 58 & 63 & 67 & 26 & 38 \\
PLK4.EHZ & 29 & 9 & 4 & 1 & 0 \\
PLK5.EHZ & 30 & 29 & 45 & 14 & 18 \\
PLWL.EHZ & 14 & 5 & 8 & 0 & 3 \\
\hline
\end{tabular}

Table 4.23. Data-use scores by year for Alaska Volcano Observatory seismograph stations in the Mount Veniaminof subnetwork, 2013-17.

\begin{tabular}{lccccc}
\hline Station & $\mathbf{2 0 1 3}$ & $\mathbf{2 0 1 4}$ & $\mathbf{2 0 1 5}$ & $\mathbf{2 0 1 6}$ & $\mathbf{2 0 1 7}$ \\
\hline BPBC.EHZ & 0 & 0 & 0 & 0 & 0 \\
VNFG.EHZ & 57 & 63 & 11 & 40 & 40 \\
VNHG.EHZ & 64 & 80 & 16 & 64 & 62 \\
VNKR.EHZ & 0 & 0 & 0 & 2 & 43 \\
VNNF.EHZ & 21 & 62 & 0 & 2 & 44 \\
VNSG.EHZ & 64 & 90 & 0 & 9 & 41 \\
VNSS.EHZ & 67 & 97 & 0 & 4 & 61 \\
VNSW.EHZ & 0 & 0 & 0 & 0 & 23 \\
VNWF.EHZ & 29 & 100 & 0 & 4 & 49 \\
\hline
\end{tabular}


Table 4.24. Data-use scores by year for Alaska Volcano Observatory seismograph stations in the Westdahl Peak subnetwork, 2013-17. [NA, not applicable]

\begin{tabular}{lccccc}
\hline \multicolumn{1}{r}{ Station } & $\mathbf{2 0 1 3}$ & $\mathbf{2 0 1 4}$ & $\mathbf{2 0 1 5}$ & $\mathbf{2 0 1 6}$ & $\mathbf{2 0 1 7}$ \\
\hline WEBT.BHZ & NA & NA & NA & NA & 2 \\
WEBT.EHZ & 47 & 43 & 45 & 68 & 42 \\
WECS.BHZ & NA & NA & 0 & 0 & 31 \\
WECS.EHZ & 9 & 43 & 66 & 78 & 43 \\
WESE.EHZ & 32 & 39 & 56 & 80 & 74 \\
WESN.EHZ & 31 & 8 & 53 & 84 & 41 \\
WESP.EHZ & 51 & 48 & 59 & 63 & 57 \\
WTUG.EHZ & 0 & 45 & 54 & 53 & 1 \\
\hline
\end{tabular}

Table 4.25. Data-use scores by year for Alaska Volcano Observatory seismograph stations in the Mount Wrangell subnetwork, 2013-17.

[NA, not applicable]

\begin{tabular}{rccccc}
\hline Station & $\mathbf{2 0 1 3}$ & $\mathbf{2 0 1 4}$ & $\mathbf{2 0 1 5}$ & $\mathbf{2 0 1 6}$ & $\mathbf{2 0 1 7}$ \\
\hline WACK.BHZ & NA & NA & NA & 0 & 138 \\
WACK.EHZ & 0 & 0 & 0 & 0 & NA \\
WANC.EHZ & 0 & 0 & 0 & 0 & 0 \\
WASW.EHZ & 0 & 0 & 0 & 0 & NA \\
WASW.SHZ & NA & NA & NA & 0 & 106 \\
WAZA.BHZ & NA & NA & NA & NA & 67 \\
WAZA.EHZ & 0 & 0 & 0 & 0 & NA \\
\hline
\end{tabular}

Table 4.26. Data-use scores by year for Alaska Volcano Observatory regional seismograph stations, 2013-17.

[NA, not applicable]

\begin{tabular}{lccccc}
\hline \multicolumn{1}{r}{ Station } & $\mathbf{2 0 1 3}$ & $\mathbf{2 0 1 4}$ & $\mathbf{2 0 1 5}$ & $\mathbf{2 0 1 6}$ & $\mathbf{2 0 1 7}$ \\
\hline ADAG.EHZ & 75 & 56 & 52 & 39 & 16 \\
AMKA.BHZ & 5 & 72 & 79 & 30 & 15 \\
BGM.EHZ & 0 & 0 & 0 & 0 & 0 \\
BGR.EHZ & 0 & 0 & 0 & 0 & 0 \\
BKG.EHZ & 0 & 0 & 0 & 0 & 0 \\
ETKA.EHZ & 69 & 18 & 24 & 39 & 3 \\
MMN.EHZ & 2 & 0 & 0 & 0 & 0 \\
OPT.EHZ & 0 & 35 & 42 & 15 & 18 \\
PDB.EHZ & 2 & 0 & 0 & 0 & 0 \\
STLK.BHZ & NA & NA & NA & NA & 23 \\
STLK.EHZ & 0 & 214 & 368 & 371 & 244 \\
STLK.SHZ & NA & NA & NA & 0 & 0 \\
SYI.EHZ & 0 & 0 & 0 & 0 & 0 \\
\hline
\end{tabular}


This page left blank intentionally 


\section{Appendix 5. Seismic-Velocity Models Used for Locating Earthquakes}

One-dimensional velocity models used by the Alaska Volcano Observatory for earthquake location are given in tables 5.1-5.14. Depths are referenced to sea level, with negative values reflecting height above sea level. Cylindrical regions where the models were applied are described in appendix 6. 
Table 5.1. Velocity model used by the Alaska Volcano Observatory for Akutan Peak (Power and others, 1996).

$\left[V_{\mathrm{P}}, \mathrm{P}\right.$-wave or compressional-wave velocity; $V_{\mathrm{S}}$, S-wave or shear-wave velocity]

\begin{tabular}{cccc}
\hline Layer & $\mathrm{V}_{\mathrm{p}}$ in kilometers per second & Top of layer, in kilometers & $\mathrm{V}_{\mathrm{p}} / \mathrm{V}_{\mathrm{s}}$ \\
\hline 1 & 2.30 & -3.0 & 1.80 \\
2 & +0.37 per km depth & 7.0 & 1.80 \\
\hline
\end{tabular}

Table 5.2. Velocity model used by the Alaska Volcano Observatory for the Andreanof Islands region (Toth and Kisslinger, 1984).

$\left[V_{\mathrm{P}}, \mathrm{P}\right.$-wave or compressional-wave velocity; $V_{\mathrm{S}}$, S-wave or shear-wave velocity]

\begin{tabular}{cccc}
\hline Layer & $V_{p}$ in kilometers per second & Top of layer, in kilometers & $V_{p} / V_{s}$ \\
\hline 1 & 3.50 & -3.0 & 1.73 \\
2 & 3.88 & -2.8 & 1.73 \\
3 & 4.25 & -2.6 & 1.73 \\
4 & 4.62 & -2.4 & 1.73 \\
5 & 5.00 & -2.2 & 1.73 \\
6 & 5.50 & -2.0 & 1.73 \\
7 & 5.62 & -1.0 & 1.73 \\
8 & 5.74 & 0.0 & 1.73 \\
9 & 5.86 & 1.0 & 1.73 \\
10 & 5.98 & 2.0 & 1.73 \\
11 & 6.10 & 3.0 & 1.73 \\
12 & 6.60 & 4.0 & 1.73 \\
13 & 6.68 & 5.0 & 1.73 \\
14 & 6.80 & 8.0 & 1.73 \\
15 & 6.92 & 11.0 & 1.73 \\
16 & 7.04 & 14.0 & 1.73 \\
17 & 7.16 & 17.0 & 1.73 \\
18 & 7.28 & 20.0 & 1.73 \\
19 & 7.85 & 23.0 & 1.73 \\
20 & 8.05 & 37.0 & 1.73 \\
\hline
\end{tabular}

Table 5.3. Velocity model used by the Alaska Volcano Observatory for Augustine Volcano (Power, 1988).

$\left[V_{\mathrm{P}}, \mathrm{P}\right.$-wave or compressional-wave velocity; $V_{\mathrm{S}}$, S-wave or shear-wave velocity $]$

\begin{tabular}{cccc}
\hline Layer & $\mathrm{V}_{\mathrm{p}}$ in kilometers per second & Top of layer, in kilometers & $\mathrm{V}_{\mathrm{p}} / \mathrm{V}_{\mathrm{s}}$ \\
\hline 1 & 2.3 & -3.0 & 1.80 \\
2 & 2.6 & -0.7 & 1.80 \\
3 & 3.4 & 0.0 & 1.80 \\
4 & 5.1 & 1.0 & 1.80 \\
5 & 6.3 & 9.0 & 1.78 \\
6 & 8.0 & 44.0 & 1.78 \\
\hline
\end{tabular}


Table 5.4. Velocity model used by the Alaska Volcano Observatory for Cold Bay region (McNutt and Jacob, 1986).

[ $V_{\mathrm{P}}, \mathrm{P}$-wave or compressional-wave velocity; $V_{\mathrm{S}}$, S-wave or shear-wave velocity]

\begin{tabular}{cccc}
\hline Layer & $\mathrm{V}_{\mathrm{p}}$ in kilometers per second & Top of layer, in kilometers & $\mathrm{V}_{\mathrm{p}} / \mathrm{V}_{\mathrm{s}}$ \\
\hline 1 & 3.05 & -3.00 & 1.78 \\
2 & 3.44 & 0.00 & 1.78 \\
3 & 5.56 & 1.79 & 1.78 \\
4 & 6.06 & 3.65 & 1.78 \\
5 & 6.72 & 10.18 & 1.78 \\
6 & 7.61 & 22.63 & 1.78 \\
7 & 7.90 & 38.51 & 1.78 \\
\hline
\end{tabular}

Table 5.5. Velocity model used by the Alaska Volcano Observatory for lliamna Volcano (Roman and others, 2001).

[ $V_{\mathrm{P}}, \mathrm{P}$-wave or compressional-wave velocity; $V_{\mathrm{S}}, \mathrm{S}$-wave or shear-wave velocity]

\begin{tabular}{cccc}
\hline Layer & $\mathrm{V}_{\mathrm{p}}$ in kilometers per second & Top of layer, in kilometers & $\mathrm{V}_{\mathrm{p}} / \mathrm{V}_{\mathrm{s}}$ \\
\hline 1 & 4.8 & -3.0 & 1.78 \\
2 & 6.1 & -1.6 & 1.78 \\
3 & 6.2 & 1.7 & 1.78 \\
4 & 6.3 & 2.9 & 1.78 \\
5 & 6.4 & 3.1 & 1.78 \\
6 & 7.1 & 16.5 & 1.78 \\
\hline
\end{tabular}

Table 5.6. Velocity model used by the Alaska Volcano Observatory for the Katmai volcanic cluster (Searcy, 2003).

[ $V_{\mathrm{P}}, \mathrm{P}$-wave or compressional-wave velocity; $V_{\mathrm{S}}$, S-wave or shear-wave velocity]

\begin{tabular}{cccc}
\hline Layer & $\mathrm{V}_{\mathrm{p}}$ in kilometers per second & Top of layer, in kilometers & $\mathrm{V}_{\mathrm{p}} / \mathrm{V}_{\mathrm{s}}$ \\
\hline 1 & 5.05 & -3.0 & 1.78 \\
2 & 5.10 & 1.0 & 1.78 \\
3 & 5.41 & 2.0 & 1.78 \\
4 & 5.49 & 3.0 & 1.78 \\
5 & 5.65 & 4.0 & 1.78 \\
6 & 5.67 & 5.0 & 1.78 \\
7 & 5.69 & 6.0 & 1.78 \\
8 & 5.76 & 7.0 & 1.78 \\
9 & 5.80 & 8.0 & 1.78 \\
10 & 6.00 & 9.0 & 1.78 \\
11 & 6.04 & 10.0 & 1.78 \\
12 & 6.08 & 12.0 & 1.78 \\
13 & 6.30 & 15.0 & 1.78 \\
14 & 6.73 & 20.0 & 1.78 \\
15 & 7.54 & 25.0 & 1.78 \\
16 & 7.78 & 33.0 & 1.78 \\
\hline
\end{tabular}


Table 5.7. Velocity model used by the Alaska Volcano Observatory for Makushin Volcano (Cheryl Searcy, written communications, 2010).

$\left[V_{\mathrm{P}}, \mathrm{P}\right.$-wave or compressional-wave velocity; $V_{\mathrm{S}}$, S-wave or shear-wave velocity $]$

\begin{tabular}{cccc}
\hline Layer & $\mathrm{V}_{\mathrm{p}}$ in kilometers per second & Top of layer, in kilometers & $\mathrm{V}_{\mathrm{p}} / \mathrm{V}_{\mathrm{s}}$ \\
\hline 1 & 3.88 & -3.0 & 1.86 \\
2 & 3.92 & 0.0 & 1.88 \\
3 & 3.99 & 1.0 & 1.61 \\
4 & 4.11 & 2.0 & 1.66 \\
5 & 4.81 & 3.0 & 1.70 \\
6 & 5.40 & 4.0 & 1.91 \\
7 & 5.82 & 4.5 & 1.77 \\
8 & 6.40 & 5.0 & 1.70 \\
9 & 6.53 & 9.0 & 1.68 \\
10 & 6.92 & 10.0 & 1.71 \\
11 & 7.37 & 11.0 & 1.82 \\
12 & 7.68 & 23.0 & 1.78 \\
13 & 8.08 & 28.0 & 1.78 \\
\hline
\end{tabular}

Table 5.8. Velocity model used by the Alaska Volcano Observatory for Okmok Caldera (Masterlark and others, 2010).

$\left[V_{\mathrm{P}}, \mathrm{P}\right.$-wave or compressional-wave velocity; $V_{\mathrm{S}}$, S-wave or shear-wave velocity]

\begin{tabular}{cccc}
\hline Layer & $\mathrm{V}_{\mathrm{p}}$ in kilometers per second & Top of layer, in kilometers & $\mathrm{V}_{\mathrm{p}} / \mathrm{V}_{\mathrm{s}}$ \\
\hline 1 & 3.830 & -3.0 & 1.73 \\
2 & 3.891 & 0.0 & 1.73 \\
3 & 5.084 & 1.0 & 1.73 \\
4 & 5.187 & 2.0 & 1.73 \\
5 & 5.470 & 3.0 & 1.73 \\
6 & 6.185 & 4.0 & 1.73 \\
7 & 6.191 & 10.0 & 1.73 \\
8 & 6.454 & 12.0 & 1.73 \\
9 & 6.896 & 16.0 & 1.73 \\
10 & 7.414 & 20.0 & 1.73 \\
\hline
\end{tabular}

Table 5.9. Velocity model used by the Alaska Volcano Observatory for Redoubt Volcano (Lahr and others, 1994).

$\left[V_{\mathrm{P}}, \mathrm{P}\right.$-wave or compressional-wave velocity; $V_{\mathrm{S}}$, S-wave or shear-wave velocity]

\begin{tabular}{cccc}
\hline Layer & $\mathrm{V}_{\mathrm{p}}$ in kilometers per second & Top of layer, in kilometers & $\mathrm{V}_{\mathrm{p}} / \mathrm{V}_{\mathrm{s}}$ \\
\hline 1 & 2.90 & -3.0 & 1.80 \\
2 & 5.10 & -1.7 & 1.80 \\
3 & 6.40 & 1.5 & 1.72 \\
4 & 7.00 & 17.0 & 1.78 \\
\hline
\end{tabular}


Table 5.10. Velocity model used by the Alaska Volcano Observatory for Mount Spurr (Jolly and others, 1994).

[ $V_{\mathrm{P}}, \mathrm{P}$-wave or compressional-wave velocity; $V_{\mathrm{S}}$, S-wave or shear-wave velocity]

\begin{tabular}{cccc}
\hline Layer & $\mathrm{V}_{\mathrm{p}}$ in kilometers per second & Top of layer, in kilometers & $\mathrm{V}_{\mathrm{p}} / \mathrm{V}_{\mathrm{s}}$ \\
\hline 1 & 5.1 & -3.00 & 1.81 \\
2 & 5.5 & -2.00 & 1.81 \\
3 & 6.3 & 5.25 & 1.74 \\
4 & 7.2 & 27.25 & 1.78 \\
\hline
\end{tabular}

Table 5.11. Velocity model used by the Alaska Volcano Observatory for Tanaga Volcano (Power, written commun., 2005).

[ $V_{\mathrm{P}}, \mathrm{P}$-wave or compressional-wave velocity; $V_{\mathrm{S}}$, S-wave or shear-wave velocity]

\begin{tabular}{cccc}
\hline Layer & $\mathrm{V}_{\mathrm{p}}$ in kilometers per second & Top of layer, in kilometers & $\mathrm{V}_{\mathrm{p}} / \mathrm{V}_{\mathrm{s}}$ \\
\hline 1 & 4.0 & -3.0 & 1.78 \\
2 & 4.5 & -1.2 & 1.78 \\
3 & 5.0 & 0.0 & 1.78 \\
4 & 5.6 & 4.0 & 1.78 \\
5 & 6.9 & 10.0 & 1.78 \\
6 & 7.2 & 15.0 & 1.78 \\
7 & 7.8 & 20.0 & 1.78 \\
8 & 8.1 & 33.0 & 1.78 \\
\hline
\end{tabular}

Table 5.12. Velocity model used by the Alaska Volcano Observatory for Mount Veniaminof (Sánchez, 2005).

$\left[V_{\mathrm{P}}, \mathrm{P}\right.$-wave or compressional-wave velocity; $V_{\mathrm{S}}$, S-wave or shear-wave velocity]

\begin{tabular}{cccc}
\hline Layer & $\mathrm{V}_{\mathrm{p}}$ in kilometers per second & Top of layer, in kilometers & $\mathrm{V}_{\mathrm{p}} / \mathrm{V}_{\mathrm{s}}$ \\
\hline 1 & 4.82 & -3.0 & 1.73 \\
2 & 5.23 & 4.0 & 1.88 \\
3 & 5.23 & 10.0 & 1.38 \\
4 & 6.49 & 15.0 & 1.65 \\
5 & 6.52 & 20.0 & 1.51 \\
6 & 8.18 & 25.0 & 1.89 \\
7 & 8.21 & 33.0 & 1.90 \\
8 & 8.21 & 47.0 & 1.80 \\
9 & 8.30 & 65.0 & 1.78 \\
\hline
\end{tabular}


Table 5.13. Velocity model used by the Alaska Volcano Observatory for Westdahl Peak (Dixon and others, 2005).

$\left[V_{\mathrm{P}}, \mathrm{P}\right.$-wave or compressional-wave velocity; $V_{\mathrm{S}}$, S-wave or shear-wave velocity]

\begin{tabular}{cccc}
\hline Layer & $\mathrm{V}_{\mathrm{p}}$ in kilometers per second & Top of layer, in kilometers & $\mathrm{V}_{\mathrm{p}} / \mathrm{V}_{\mathrm{s}}$ \\
\hline 1 & 3.03 & -3.0 & 1.71 \\
2 & 3.18 & 0.0 & 1.71 \\
3 & 5.03 & 2.0 & 1.71 \\
4 & 5.70 & 8.0 & 1.71 \\
5 & 6.30 & 10.0 & 1.71 \\
6 & 6.82 & 16.0 & 1.71 \\
7 & 7.17 & 26.0 & 1.71 \\
8 & 8.16 & 38.0 & 1.71 \\
\hline
\end{tabular}

Table 5.14. Regional velocity model used by the Alaska Volcano Observatory (Fogleman and others, 1993).

$\left[V_{\mathrm{P}}, \mathrm{P}\right.$-wave or compressional-wave velocity; $V_{\mathrm{S}}$, S-wave or shear-wave velocity]

\begin{tabular}{cccc}
\hline Layer & $\boldsymbol{V}_{\mathrm{p}}$ in kilometers per second & Top of layer, in kilometers & $\mathrm{V}_{\mathrm{p}} / \mathrm{V}_{\mathrm{s}}$ \\
\hline 1 & 5.3 & -3.0 & 1.78 \\
2 & 5.6 & 4.0 & 1.78 \\
3 & 6.2 & 10.0 & 1.78 \\
4 & 6.9 & 15.0 & 1.78 \\
5 & 7.4 & 20.0 & 1.78 \\
6 & 7.7 & 25.0 & 1.78 \\
7 & 7.9 & 33.0 & 1.78 \\
8 & 8.1 & 47.0 & 1.78 \\
9 & 8.3 & 65.0 & 1.78 \\
\hline
\end{tabular}




\section{Appendix 6. Cylindrical Model Regions Used for Locating Earthquakes}

This appendix shows the cylindrical model regions used by the Alaska Volcano Observatory for locating earthquakes. Table 6.1 gives cylindrical extent parameters for local velocity models used at each volcano, and figures 6.1-6.4 show the cylindrical model regions defined by multiple cylinders. 
Table 6.1. Cylindrical extent parameters for local velocity models used by the Alaska Volcano Observatory at monitored volcanoes.

[Latitude and longitude are the center of each model. Depths of the top and bottom of each model are referenced to sea level with negative depths reflecting height above sea level. The one-dimensional models applied in each cylindrical area are given in tables in appendix 5]

\begin{tabular}{|c|c|c|c|c|c|c|}
\hline Volcano/region & Velocity model & Latitude & Longitude & $\begin{array}{l}\text { Radius, in } \\
\text { kilometers }\end{array}$ & $\begin{array}{l}\text { Top depth, in } \\
\text { kilometers }\end{array}$ & $\begin{array}{l}\text { Bottom depth, in } \\
\text { kilometers) }\end{array}$ \\
\hline Mount Spurr & Table 5.10 & 61.60 & -152.40 & 20 & -3.3 & 50 \\
\hline Mount Spurr & Table 5.10 & 61.47 & -152.33 & 20 & -3.3 & 50 \\
\hline Mount Spurr & Table 5.10 & 61.33 & -152.25 & 20 & -3.3 & 50 \\
\hline Mount Spurr & Table 5.10 & 61.17 & -152.35 & 20 & -3.3 & 50 \\
\hline Mount Spurr & Table 5.10 & 61.00 & -152.45 & 20 & -3.3 & 50 \\
\hline Redoubt Volcano & Table 5.10 & 60.83 & -152.55 & 20 & -2.0 & 50 \\
\hline Redoubt Volcano & Table 5.9 & 60.66 & -152.66 & 20 & -2.0 & 50 \\
\hline Redoubt Volcano & Table 5.9 & 60.49 & -152.75 & 20 & -2.0 & 50 \\
\hline Redoubt Volcano & Table 5.9 & 60.34 & -152.86 & 20 & -2.0 & 50 \\
\hline Iliamna Volcano & Table 5.5 & 60.03 & -153.09 & 20 & -3.0 & 50 \\
\hline Augustine Volcano & Table 5.3 & 59.36 & -153.42 & 20 & -1.3 & 50 \\
\hline $\begin{array}{l}\text { Katmai volcanic } \\
\text { cluster }\end{array}$ & Table 5.6 & 58.17 & -155.35 & 20 & -2.3 & 50 \\
\hline $\begin{array}{l}\text { Katmai volcanic } \\
\text { cluster }\end{array}$ & Table 5.6 & 58.29 & -154.86 & 20 & -2.3 & 50 \\
\hline $\begin{array}{l}\text { Katmai volcanic } \\
\text { cluster }\end{array}$ & Table 5.6 & 58.35 & -155.09 & 20 & -2.3 & 50 \\
\hline $\begin{array}{l}\text { Katmai volcanic } \\
\text { cluster }\end{array}$ & Table 5.6 & 58.43 & -154.38 & 20 & -2.3 & 50 \\
\hline Mount Veniaminof & Table 5.12 & 56.18 & -159.38 & 30 & -2.5 & 50 \\
\hline Cold Bay & Table 5.4 & 55.42 & -161.89 & 20 & -2.8 & 50 \\
\hline Cold Bay & Table 5.4 & 55.18 & -162.27 & 20 & -2.8 & 50 \\
\hline Cold Bay & Table 5.4 & 54.76 & -163.97 & 30 & -2.8 & 50 \\
\hline Westdahl Peak & Table 5.13 & 54.52 & -164.65 & 20 & -1.5 & 50 \\
\hline Akutan Peak & Table 5.1 & 54.15 & -165.97 & 20 & -1.3 & 50 \\
\hline Makushin Volcano & Table 5.7 & 53.89 & -166.92 & 20 & -1.8 & 50 \\
\hline Okmok Caldera & Table 5.8 & 53.40 & -168.16 & 20 & -1.1 & 50 \\
\hline Andreanof Islands & Table 5.2 & 52.08 & -176.13 & 20 & -1.7 & 50 \\
\hline Andreanof Islands & Table 5.2 & 51.93 & -176.75 & 20 & -1.7 & 50 \\
\hline Andreanof Islands & Table 5.2 & 51.92 & -177.17 & 20 & -1.7 & 50 \\
\hline Tanaga Volcano & Table 5.11 & 51.89 & -178.15 & 20 & -1.8 & 50 \\
\hline
\end{tabular}




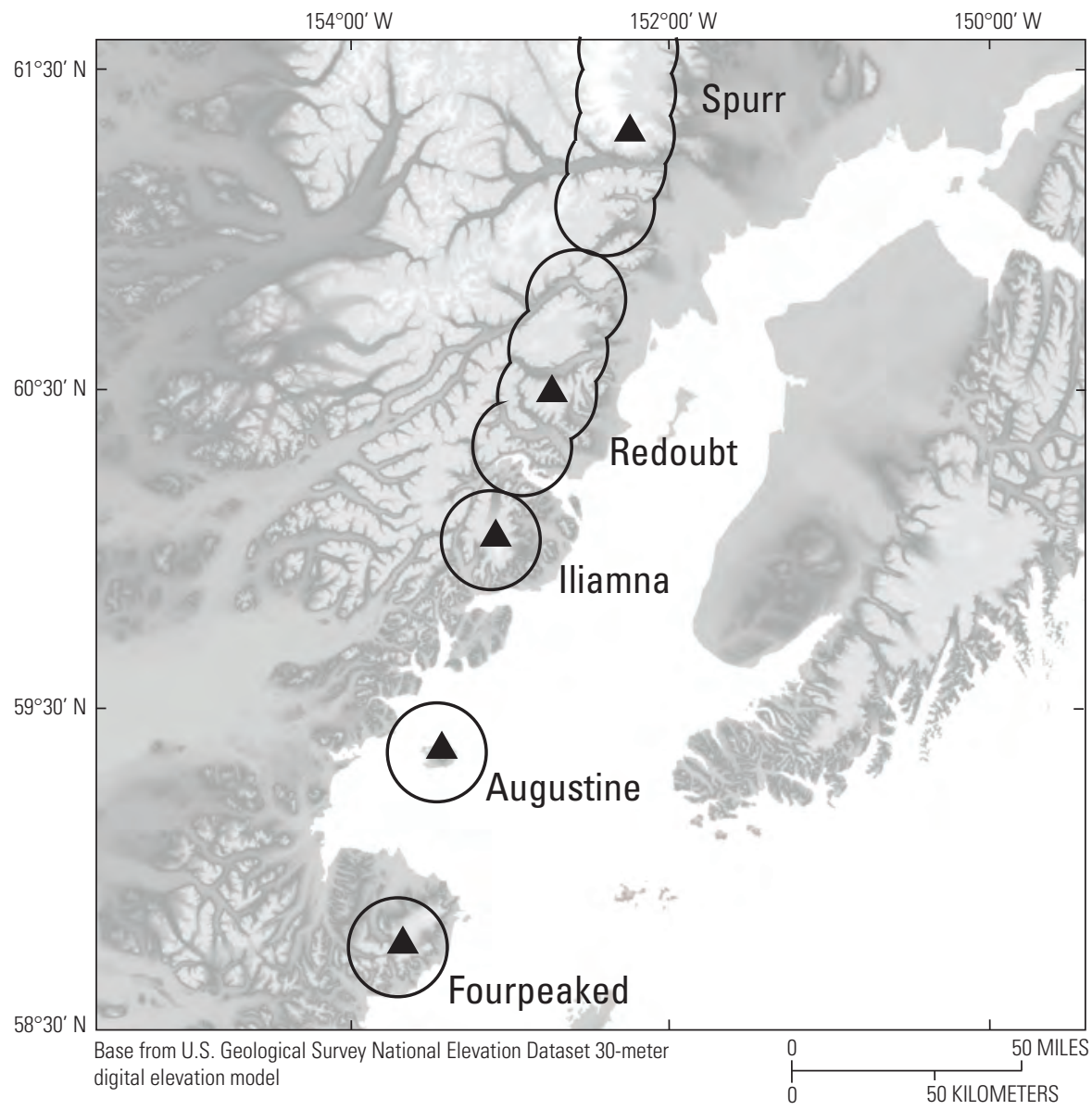

Figure 6.1. Map showing volcanic zones for the Cook Inlet volcanoes, Alaska. Five overlapping cylinders model the Mount Spurr volcanic zone. Four overlapping cylinders model the Redoubt volcanic zone. Single cylinders model the lliamna Volcano, Augustine Volcano, and Fourpeaked Mountain volcanic zones. See figure 1 for map location.

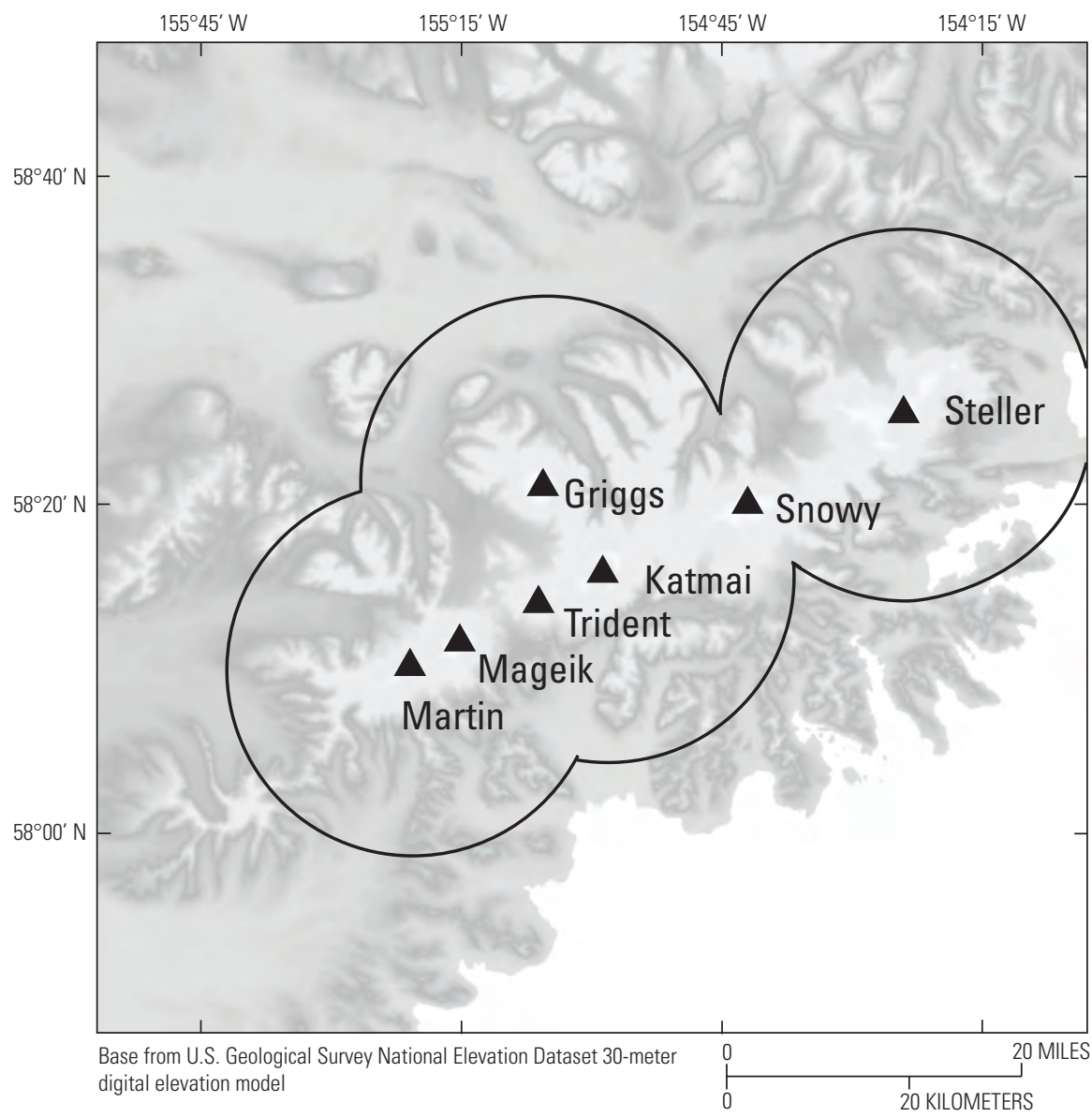

Figure 6.2. Map showing the volcanic zone for the Katmai volcanic cluster, Alaska. The volcanic zone is modeled using four overlapping cylinders centered on Mount Martin, Mount Katmai, Mount Griggs, and Mount Steller. See figure 1 for map location. 

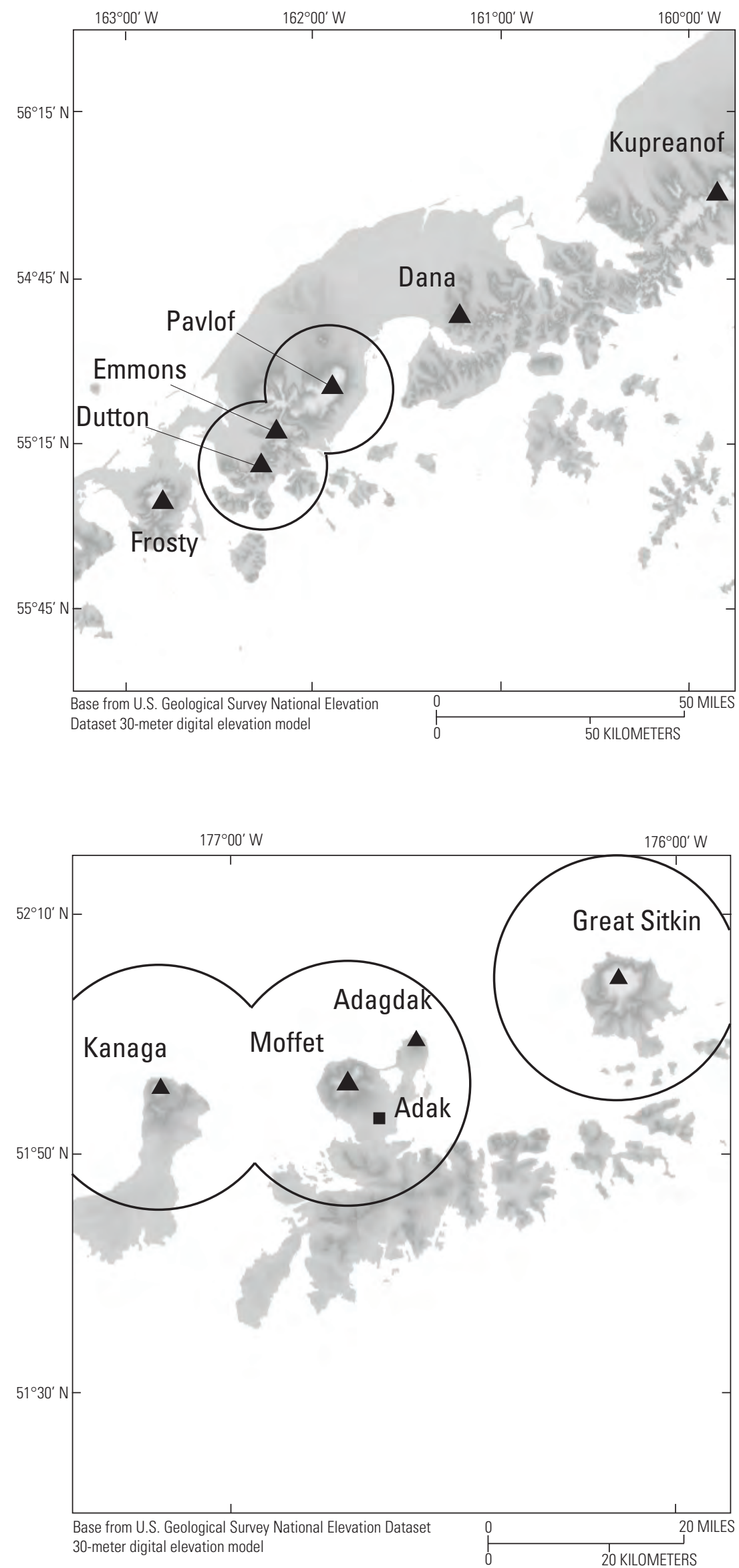

Figure 6.3. Map showing the volcanic zones for Pavlof Volcano and Mount Dutton, Alaska. The volcanic zone is modeled using two overlapping cylinders centered on Mount Dutton and Pavlof VolcanoSee figure 1 for map location (Mount Dana, Mount Emmons, Mount Kupreanof, and Frosty Peak are not shown).
Figure 6.4. Map showing the volcanic zones in the Adak region, Alaska. The volcanic zones are modeled using cylinders centered on Kanaga Volcano, Mount Moffett, and Great Sitkin Volcano See figure 1 for map location (Mount Moffett and Mount Adagdak are not shown). 


\section{Appendix 7. Description of Earthquake List Parameters}

The data supplement that accompanies this report (ds1115_datasupplement.zip; available only online at https://doi.org/10.3133/ds1115) includes an Excel (.xlsx) spreadsheet (also available as a comma separated value, .csv, file)—ds1115_2013to2017earthquakesummary. $\mathrm{xlsx}$ - that has a listing of all volcano-related seismic events included in the Alaska Volcano Observatory catalog of seismic events recorded by the Advanced National Seismic System (ANSS) Quake Monitoring System. The following parameters are used in the catalog (shown as formatted in the data supplement):

- Date and time in Coordinated Universal Time (year, month, day, hour, minute, and second)

- Hypocenter in latitude and longitude in decimal degrees in the World Geodetic System 1984 (WGS 84) datum. Depth is specified in kilometers below mean sea level.

- Magnitude — magnitude (mag) and magnitude type (mag type) — with local magnitude $\left(M_{L}\right)$ being the preferred magnitude over duration magnitude $\left(M_{d}\right)$. If a magnitude could not be determined by other means the magnitude was set $\left(M_{h}\right)$

- Hypocentral errors are shown as the weighted root-mean-square travel-time residual error (RMS); the depth error (ERZ) defined as the largest projection of the three principal errors on a vertical line; and the horizontal error (ERH) defined as the length of the largest projection of the three principal errors on a horizontal plane.

- Event gap (gap) is the largest azimuthal gap between azimuthally adjacent stations.

- Distance to the closest seismograph station (dist).

- Number of phases (n), P-phase and S-phase combined, number of P-phases (np), and number of S-phases (ns), used in the hypocentral solution.

- Quality (quality) of the solution is a one-letter quality code based on errors and goodness-of-fit; quality criteria are:

A. RMS $\leq 0.15$ second (s) and $E R Z \leq 2.0 \mathrm{~km}$ and $E R H \leq 1.0$ kilometer $(\mathrm{km})$;

B. $R M S \leq 0.30 \mathrm{~s}$ and $\leq 5.0 \mathrm{~km}$ and $\mathrm{ERH} \leq 2.5 \mathrm{~km}$;

C. RMS $\leq 0.50 \mathrm{~s}$ and $E R Z$ erz $\leq 5.0 \mathrm{~km}$ and $E R H \leq 5.0 \mathrm{~km}$;

D. Worse than above.

- Type of event (event type) as listed in table 7.1.

- Region of the event (event region) is the full name of the geographical region as listed in table 7.2.

- Volcanic Center which the earthquake is closest to.

- Database ID (event id) is a unique number assigned to each event origin in the AVO AOMS database. 
Table 7.1. Event codes used in the Alaska Volcano Observatory (AVO) catalog of seismic events.

[Each event was identified by a description code and stored as a comment in the event-location pick file, which is a database parameter]

\begin{tabular}{ll}
\hline Event code & \multicolumn{1}{c}{ Description } \\
\hline le & An earthquake included in the AVO catalog of which is thought to be a volcano-tectonic earthquake. \\
lp & An earthquake included in the AVO catalog of which is thought to be a low-frequency or hybrid earthquake . \\
re & An earthquake included in the AVO catalog that is thought to be tectonic in origin. \\
other & Located events with any other cause.
\end{tabular}

Table 7.2. Event regions and the volcanic center in each geographical region used in the Alaska Volcano Observatory (AVO) catalog of seismic events.

\begin{tabular}{ll}
\hline \multicolumn{1}{c}{ Event region } & \multicolumn{1}{c}{ Volcano center } \\
\hline Central Alaska & Mount Wrangell \\
Cook Inlet & Augustine Volcano, Iliamna Volcano, Redoubt Volcano, Mount Spurr \\
Alaska Peninsula & Aniakchak Crater, Mount Dutton, Fourpeaked Mountain, Katmai volcanic cluster, Pavlof \\
Volcano, Ugashik-Peulik Volcano, Mount Veniaminof & Isanotski Volcano, Shishaldin Volcano, Westdahl Peak \\
Unimak Island & Akutan Peak, Makushin Volcano, Okmok Caldera, Mount Resheshnoi \\
Fox Islands & Mount Cleveland \\
Islands of the Four Mountains & Mount Gareloi, Great Sitkin Volcano, Kanaga Volcano, Korovin Volcano, Tanaga Volcano \\
Andreanof Islands & Mount Cerberus, Little Sitkin Volcano \\
Rat Islands &
\end{tabular}




\section{Appendix 8. Previous Alaska Volcano Observatory Earthquake Catalogs}

1989-90: Power, J.A., March, G.D., Lahr, J.C., Jolly, A.D., and Cruse, G.R., 1993, Catalog of earthquake hypocenters at Redoubt Volcano and Mount Spurr, Alaska-October 12, 1989-December 31, 1990: U.S. Geological Survey Open-File Report 93-685-A, 57 p., https://doi.org/10.3133/ ofr93685A.

1991-93: Jolly, A.D., Power, J.A., Stihler, S.D., Rao, L.N., Davidson, G., Paskievitch, J., Estes, S., and Lahr, J.C., 1996, Catalog of earthquake hypocenters for Augustine, Redoubt, Iliamna, and Mount Spurr Volcanoes, AlaskaJanuary 1, 1991-December 31, 1993: U.S. Geological Survey Open-File Report 96-70, 90 p., https://doi.org/10.3133/ ofr9670.

1994-99: Jolly, A.D., Stihler, S.D., Power, J.A., Lahr, J.C., Paskievitch, J., Tytgat, G., Estes, S., Lockhart, A.B., Moran, S.C., McNutt, S.R., and Hammond, W.R., 2001, Catalog of earthquake hypocenters at Alaskan volcanoes-January 1, 1994-December 31, 1999: U.S. Geological Survey Open-File Report 01-189, 202 p., https://doi.org/10.3133/ ofr01189.

2000-01: Dixon, J.P, Stihler, S.D., Power, J.A., Tytgat, G., Estes, S., Moran, S.C., Paskievitch, J., and McNutt, S.R., 2002, Catalog of earthquake hypocenters at Alaska volcanoes-January 1, 2000-December 31, 2001: U.S. Geological Survey Open-File Report 02-342, 56 p., https://doi. org/10.3133/ofr02342.

2002: Dixon, J.P., Stihler, S.D., Power, J.A., Tytgat, G., Moran, S.C., Sánchez, J.J., Estes, S., McNutt, S.R., and Paskievitch, J., 2003, Catalog of earthquake hypocenters at Alaska volcanoes-January 1-December 31, 2002: U.S. Geological Survey Open-File Report 03-267, 58 p., https:// doi.org/10.3133/ofr03267.

2003: Dixon, J.P., Stihler, S.D., Power, J.A., Tytgat, G., Moran, S.C., Sánchez, J.J., Estes, S., McNutt, S.R., and Paskievitch, J., 2004, Catalog of earthquake hypocenters at Alaska volcanoes-January 1-December 31, 2003: U.S. Geological Survey Open-File Report 2004-1234, 59 p., https://doi.org/10.3133/ofr20041234.

2004: Dixon, J.P., Stihler, S.D., Power, J.A., Tytgat, G., Estes, S., Prejean, S.G., Sánchez, J.J., Sanches, R., McNutt, S.R., and Paskievitch, J., 2005, Catalog of earthquake hypocenters at Alaskan volcanoes-January 1 through December 31, 2004: U.S. Geological Survey Open-File Report 2005-1312, 74 p., https://doi.org/10.3133/ofr20051312.
2005: Dixon, J.P., Stihler, S.D., Power, J.A., Tytgat, G., Estes, S., and McNutt, S.R., 2007, Catalog of earthquake hypocenters at Alaskan volcanoes-January 1 through December 31, 2005: U.S. Geological Survey OpenFile Report 2007-1264, 78 p., https://doi.org/10.3133/ ofr20061264.

2006: Dixon, J.P., Stihler, S.D., Power, J.A., and Searcy, C.K., 2008, Catalog of earthquake hypocenters at Alaskan Volcanoes_-January 1 through December 31, 2006: U.S. Geological Survey Data Series 326, 78 p., https://doi. org/10.3133/ds326.

2007: Dixon, J.P., Stihler, S.D., Power, J.A., and Searcy, C.K., 2008, Catalog of earthquake hypocenters at Alaskan volcanoes_-January 1 through December 31, 2007: U.S. Geological Survey Data Series 367, 82 p., https://doi. org/10.3133/ds367.

2008: Dixon, J.P., and Stihler, S.D, 2009, Catalog of earthquake hypocenters at Alaskan volcanoes-January 1 through December 31, 2008: U.S. Geological Survey Data Series 467, 88 p., https://doi.org/10.3133/ds467.

2009: Dixon, J.P., Stihler, S.D, Power, J.A., and Searcy, C.K., 2010, Catalog of earthquake hypocenters at Alaskan volcanoes_-January 1 through December 31, 2009: U.S. Geological Survey Data Series 531, 84 p., https://doi. org/10.3133/ds531.

2010: Dixon, J.P., Stihler, S.D, Power, J.A., and Searcy, C.K., 2011, Catalog of earthquake hypocenters at Alaskan volcanoes_-January 1 through December 31, 2010: U.S. Geological Survey Data Series 645, 82 p., https://doi. org/10.3133/ds645.

2011: Dixon, J.P., Stihler, S.D, Power, J.A., and Searcy, C.K., 2012, Catalog of earthquake hypocenters at Alaskan volcanoes_-January 1 through December 31, 2011: U.S. Geological Survey Data Series 730, 90 p., https://doi. org/10.3133/ds730.

2012: Dixon, J.P., Stihler, S.D., Power, J.A., Haney, M.M., Parker, T., Searcy, C.K., and Prejean, S.G., 2013, Catalog of earthquake hypocenters at Alaskan volcanoes_-January 1 through December 31, 2012: U.S. Geological Survey Data Series 789, 84 p., https://doi.org/10.3133/ds789. 


\section{Appendix 9. Selected Publications Using Alaska Volcano Observatory Data}

Bennington, N.L., Haney, M.M., De Angelis, S., Thurber, C.H., and Freymueller, J., 2015, Monitoring changes in seismic velocity related to an ongoing rapid inflation event at Okmok volcano, Alaska: Journal of Geophysical Research Solid Earth, v. 120 , no. 8, p. 5664-5676, https:// doi.org/10.1002/2015JB011939.

Brown, J.R., Prejean, S.G., Beroza, G.C., Gomberg, J.S., and Haeussler, P.J., 2013, Deep low-frequency earthquakes in tectonic tremor along the Alaska-Aleutian subduction zone: Journal of Geophysical Research B-Solid Earth, v. 118, no. 3, p. 1079-1090, https://doi.org/10.1029/2012JB009459.

Bull, K.F., and Buurman, H., 2013, An overview of the 2009 eruption of Redoubt Volcano, Alaska: Journal of Volcanology and Geothermal Research, v. 259, p. 2-15, https://doi. org/10.1016/j.jvolgeores.2012.06.024.

Buurman, H., West, M.E., and Thompson, G., 2013, The seismicity of the 2009 Redoubt eruption: Journal of Volcanology and Geothermal Research, v. 259, p. 16-30, https://doi. org/10.1016/j.jvolgeores.2012.04.024.

Buurman, H., West, M.E., and Roman, D.C., 2013, Using repeating volcano-tectonic earthquakes to track posteruptive activity in the conduit system at Redoubt Volcano, Alaska: Geology, v. 41, no. 4, p. 511-514, https://doi. org/10.1130/G34089.1.

Buurman, H., and West, M.E., 2013, Magma fracture and hybrid earthquakes in the conduit of Augustine Volcano: Geophysical Research Letters, v. 40, no. 23, p. 6038-6042, https://doi.org/10.1002/2013GL057864.

Buurman, H., Nye, C.J., West, M.E., and Cameron, C.E., 2014, Regional controls on volcano seismicity along the Aleutian Arc: Geochemistry, Geophysics, Geosystems, v. 15, no. 4, p. 1147-63, https://doi.org/10.1002/2013GC005101.

Cusano, P., Palo, M., and West, M.E., 2015, Long-period seismicity at Shishaldin volcano (Alaska) in 2003-2004: Indications of an upward migration of the source before a minor eruption: Journal of Volcanology and Geothermal Research, v. 291, p. 14-24, https://doi.org/10.1016/j.jvolgeores.2014.12.008.

DeRoin, N., McNutt, S.R., and Thompson, G., 2015, Durationamplitude relationships of volcanic tremor and earthquake swarms preceding and during the 2009 eruption of Redoubt Volcano, Alaska: Journal of Volcanology and Geothermal Research, v. 292, p. 56-69, https://doi.org/10.1016/j.jvolgeores.2015.01.003.
Dmitrieva, K., Hotovec-Ellis, A.J., Prejean, S.G., and Dunham, E.M., 2013, Frictional-faulting model for harmonic tremor before Redoubt Volcano eruptions: Nature Geoscience, v., 6, no. 8, p. 652-656, https://doi.org/10.1038/ ngeo1879.

Fee, D., McNutt, S.R., Lopez, T.M., Arnoult, K.M., Szuberla, C.A.L., and Olson, J.V., 2013, Combining local and remote infrasound recordings from the 2009 Redoubt Volcano eruption: Journal of Volcanology and Geothermal Research, v. 259, p. 100-114, https://doi.org/10.1016/j. jvolgeores.2011.09.012.

Fee, D., Haney, M.M., Matoza, R., Szuberla, C., Lyons, J., and Waythomas, C., 2016, Seismic Envelope-Based Detection and Location of Ground-Coupled Airwaves from Volcanoes in Alaska, Bulletin of the Seismological Society of America, v. 106. no. 3, p. 1024-1035, https://doi. org/10.1785/0120150244.

Fee, D., Haney, M.M., Matoza, R.S., Van Eaton, A.R., Cervelli, P., Schneider, D.J., and Iezzi, A.M., 2017, Volcanic tremor and plume height hysteresis from Pavlof Volcano, Alaska: Science, v. 355, no. 6320, p. 45-48, https://doi. org/10.1126/science.aah6108.

Gomberg, J., and Prejean, S.G., 2013, Triggered tremor sweet spots in Alaska: Journal of Geophysical Research, v. 118, no. 12, p. 6203-6218, https://doi. org/10.1002/2013JB010273.

Haney, M.M., Chouet, B.A., Dawson, P.B., and Power, J.A., 2013, Source characterization for an explosion during the 2009 eruption of Redoubt Volcano from very-long-period seismic waves: Journal of Volcanology and Geothermal Research, v. 259, p. 77-88, https://doi.org/10.1016/j.jvolgeores.2012.04.018.

Haney, M.M., 2014, Backprojection of volcanic tremor: Geophysical Research Letters, v. 41, p. 1923-1928, https://doi. org/10.1002/2013GL058836.

Haney, M.M, Hotovec-Ellis, A.J., Bennington, N.L., De Angelis, S, and Thurber, C., 2015, Tracking changes in volcanic systems with seismic interferometry, in Beer, M., Kougioumtzoglou I., Patelli, E., and Au, I.S-K., eds., Encyclopedia of earthquake engineering: Springer, Berlin, Heidelberg, p. 3767-3786, https://doi.org/10.1007/978-3642-36197-5_50-1.

Haney, M.M., Matoza, R.S., Fee, D., and Aldridge, D.F., 2017, Seismic equivalents of volcanic jet scaling laws and multipoles in acoustics: Geophysical Journal International, v. 213, no. 1, p. 623-636, https://doi.org/10.1093/gji/ggx554. 
Hotovec, A.J., Prejean, S.G., Vidale, J.E., and Gomberg, J., 2013, Strongly gliding harmonic tremor during the 2009 eruption of Redoubt Volcano: Journal of Volcanology and Geothermal Research, v. 259, p. 88-99, https://doi. org/10.1016/j.jvolgeores.2012.01.001.

Kasatkina, E., Koulakov, I., West, M.E., and Izbekhov, P., 2014, Seismic structure changes beneath Redoubt Volcano during the 2009 eruption inferred from local earthquake tomography: Journal of Geophysical Research: Solid Earth, v. 119, no. 6, p. 4938-4954, https://doi. org/10.1002/2013JB010935.

Ketner, D.M., and Power, J.A., 2013, Characterization of seismic events during the 2009 eruption of Redoubt Volcano, Alaska: Journal of Volcanology and Geothermal Research, v. 259, p. 45-62, https://doi.org/10.1016/j.jvolgeores.2012.10.007.

McNutt, S.R., Thompson, G., West, M.E., Fee, D., Stihler, S., and Clark, E., 2013, Local seismic and infrasound observations of the 2009 explosive eruptions of Redoubt Volcano, Alaska: Journal of Volcanology and Geothermal Research, v. 259, p. 63-76, https://doi.org/10.1016/j.jvolgeores.2013.03.016.

Murphy, R., Thurber, C.H., Prejean, S.G., and Bennington, N., 2014, Three-dimensional seismic velocity structure and earthquake relocations at Katmai, Alaska: Journal of Volcanology and Geothermal Research, v. 276, p. 121-131, https://doi.org/10.1016/j.jvolgeores.2014.02.22.

Ohlendorf, S.J., Thurber, C.H., Pesicek, J.D., and Prejean, S.G., 2014, Seismicity and seismic structure at Okmok Volcano, Alaska: Journal of Volcanology and Geothermal Research, v. 278-279, p. 103-119, https://doi.org/10.1016/j. jvolgeores.2014.04.002.
Pollitz, F.F., Wech, A., Kao, H., and Burgmann, R., 2013, Annual modulation of non-volcanic tremor in northern Cascadia: Journal of Geophysical Research: Solid Earth, v. 118, no. 5, p. 2445-2549, https://doi.org/10.1002/jgrb.50181.

Power, J.A., Stihler, S.D., Chouet, B.A., Haney, M.M., and Ketner, D.M., 2013, Seismic observations of Redoubt Volcano, Alaska-1989-2010 and a conceptual model of the Redoubt magmatic system: Journal of Volcanology and Geothermal Research, v. 259, p. 31-44, https://doi. org/10.1016/j.jvolgeores.2012.09.014.

Roman, D.C,. and Gardine, M.D., 2013, Seismological evidence for long-term and rapidly accelerating magma pressurization preceding the 2009 eruption of Redoubt Volcano, Alaska: Earth and Planetary Science Letters, v. 371-372, p. 226-234, https://doi.org/10.1016/j.epsl.2013.03.040.

Smith, C.M., McNutt, S.R., and Thompson, G., 2016, Groundcoupled airwaves at Pavlof Volcano, Alaska, and their potential for eruption monitoring: Bulletin of Volcanology, v. 78, no. 7, p. 52-64, https://doi.org/10.1007/s00445-0161045-0.

Syracuse, E.M., Maceira, M., Zhang, H., and Thurber, C.H., 2015, Seismicity and structure of Akutan and Makushin Volcanoes, Alaska, using joint body and surface wave tomography: Journal of Geophysical Research Solid Earth, v. 120, no. 2, p. 1036-1052, https://doi. org/10.1002/2014JB011616.

Werner, C., Kern, C., Coppola, D., Lyons, J.J., Kelly, P.J., Wallace, K.L., Schneider, D.J., and Wessels, R.L., 2017, Magmatic degassing, lava dome extrusion, and explosions from Mount Cleveland volcano, Alaska, 2011-2015Insights into the continuous nature of volcanic activity over multi-year timescales: Journal of Volcanology and Geothermal Research, v. 337, p. 98-110, https://doi.org/10.1016/j. jvolgeores.2017.03.001. 
Menlo Park Publishing Service Center, California Manuscript approved for publication July 16, 2019 Edited by James W. Hendley II

Layout and design by Kimber Petersen 


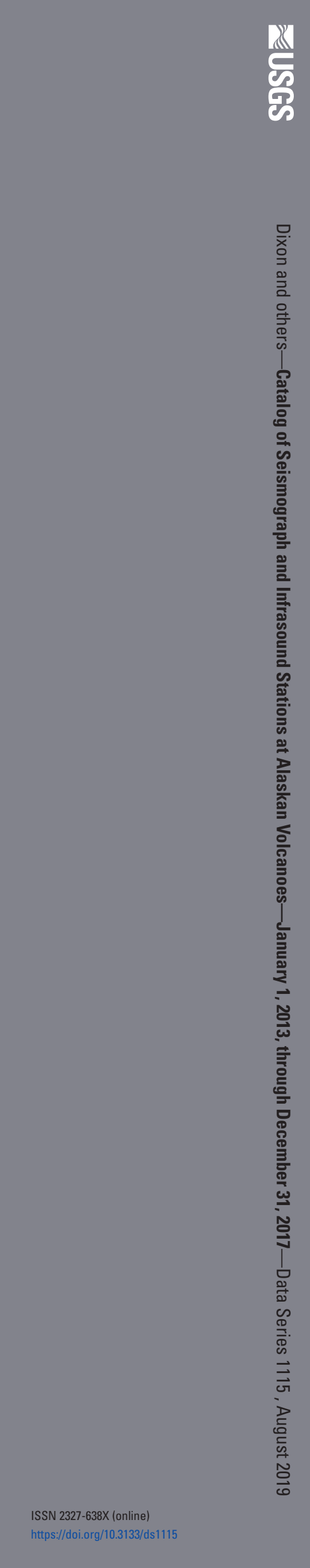

